\title{
INTERAÇÃO GENÓTIPOS $x$ LOCAIS EM LINHAGENS EXPERIMENTAIS DE SOJA COM DIFERENTES CICLOS DE MATURAÇÃO
}

\author{
MAURISRAEL DE MOURA ROCHA \\ Engenheiro Agrônomo
}

Orientador: Prof. Dr. NATAL ANTONIO VELLO

Dissertaçảo apresentada à Escola Superior de Agricultura "Luiz de Queiroz", Universidade de Sảo Paulo, para obtençảo do título de Mestre em Agronomia, Área de Concentraçąo: Genética e Melhoramento de Plantas.

P I R A C I CABA

Estado de São Paulo - Brasil

Abril - 1998 
Dados Internacionais de Catalogação na Publicação (CIP) DIVISĀO DE BIBLIOTECA E DOCUMENTAÇĀO - Campus "Luiz de Queiroz"/USP

Rocha, Maurisrael de Moura Interação genótipos $\mathrm{x}$ locais em linhagens experimentais de soja com diferentes ciclos de maturação / Maurisrael de Moura Rocha. - - Piracicaba, 1998.

98 p. : il.

Dissertaçāo (mestrado) - - Escola Superior de Agricultura Luiz de Queiroz, 1998. Bibliografia.

1. Grāo 2. Interaçāo genótipo-ambiente 3. Maturaçāo 4. Melhoramento genético 5. Óleo 6. Produtividade 7. Soja I. Título 


\section{INTERAÇÃO GENÓTIPOS $\times$ LOCAIS EM LINHAGENS EXPERIMENTAIS DE SOJA COM DIFERENTES CICLOS DE MATURAÇÃO}

\section{ERRATA}

\begin{tabular}{|c|c|c|}
\hline Página & Onde se lê & Leia-se \\
\hline vi & $22^{\circ} 39^{\prime} 00^{\prime \prime}$ de longitude Oeste & $22^{\circ} 42^{\prime} 30^{\prime \prime}$ de latitude Sul \\
\hline ix & cicles & cycles \\
\hline ix & cicle & cycle \\
\hline ix & $22^{\circ} 39^{\prime} 00^{\prime \prime}$ South latitude & $22^{\circ} 42^{\prime} 30^{\prime \prime}$ South latitude \\
\hline ix & $0.50 \mathrm{~cm}$ & $0.50 \mathrm{~m}$ \\
\hline$x$ & cicle & cycle \\
\hline$x$ & $\mathrm{e}$ & and \\
\hline 10 & etc & e outros \\
\hline 11 & etc & e outros \\
\hline 30 & valor & média \\
\hline 40 & as combinações hibridas quanto aos caracteres & os caracteres \\
\hline 42 & Krieger (1991) e Zimback (1991) & Krieger (1992) e Zimback (1992) \\
\hline 42 & engodaria & endogamia \\
\hline 43 & Zimback (1993) & Zimback (1992) \\
\hline 58 & 1993 & 1992 \\
\hline
\end{tabular}


Aos meus pais Manoel e Isabel

Ao meu irmão Everaldo

Aos meus avós Antônio, Maria da Paz e Cristovão

A todos os meus tios e primos

DEDICO

Para minha avó Adélia (in memorian)

OFEREÇO 


\section{AGRADECIMENTOS}

* A Deus, por tudo;

* Ao Professor Dr. Natal Antonio Vello, pela orientação, amizade e ensinamentos fornecidos no decorrer do curso;

* À Professora Dra. Regina Lúcia Ferreira Gomes e ao Dr. Francisco Rodrigues Freire Filho pelos incentivos e apoio fornecidos durante a minha iniciação em Genética e Melhoramento de Plantas;

* À Coordenadoria de Aperfeiçoamento de Ensino Superior (CAPES) e ao Conselho Nacional de Desenvolvimento Científico e Tecnológico (CNPq), pela concessão de bolsas de estudos;

* A EMBRAPA e FAPESP pelo financiamento de várias etapas do programa de pesquisas que originaram o germoplasma utilizado nesta dissertação;

* Ao amigo Rhainer Gleico Cardoso pelo auxílio nas análises estatísticocomputacionais;

* Aos colegas Jõao Batista Duarte e Luciano Lourenço Nass pelas sugestões na redação deste trabalho;

* Aos amigos piauienses, Ângela Célis de Almeida Lopes, Maria Cândida de Almeida Lopes, Maria Teresa do Rêgo Lopes e Edson Alves Bastos, pela companheirismo e amizade em todos os momentos de minha estadia em Piracicaba; 
* Aos amigos do grupo da soja, Claudio Yuji Tutzumi, Diego Omar Soldini, Fábio Pandini, Fernando Toledo de Miranda, Gilberto Ken-Iti Yokomizo, Sandra Helena Unêda Trevisoli, pela amizade e auxílios prestados durante o curso;

* Aos professores do Departamento de Genética da ESALQ/ USP que direta ou indiretamente contribuíram para minha formação em Genética Melhoramento de Plantas;

* Aos funcionários do Setor de Genética Aplicada às Espécies Autógamas, Antônio Roberto Cogo, Claudinei Antônio Didoné e Marcos Custódio Nekatschalow, pelos auxílio fornecidos no preparo e instalação dos experimentos;

* Às funcionárias da Biblioteca da Genética, Elizabeth dos Santos e Silvana Gregório, pela atenção fornecida na revisão das referências bibliográficas;

* A todos os amigos de curso, em particular a Adriana Cristina Alves, Maria Imaculada Zuchi e Wellington Luiz de Araújo, pela amizade e convivência durante $o$ curso. 


\section{SUMÁRIO}

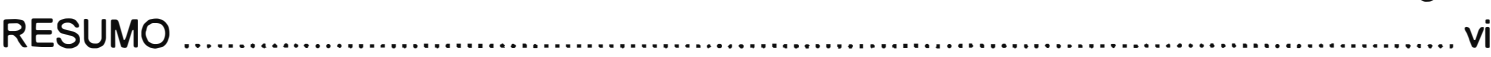

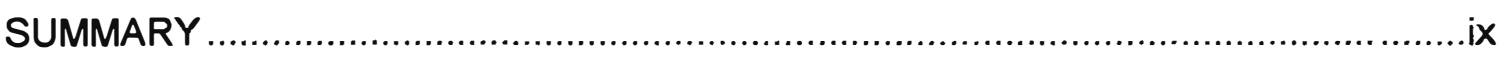

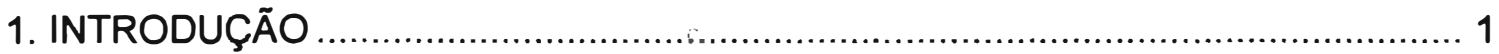

2. REVISÃO DE LITERATURA ...................................................................... 3

2.1 Origem, taxonomia e citogenética da soja.................................................. 3

2.2 Expanș ${ }^{\circ}$ e e importância sócio-econômica da soja ...................................... 3

2.3 Melhoramento genético da soja................................................................ 4

2.4 Aspectos da interação genótipos $x$ ambientes $(G \times E)$. ........................... 5

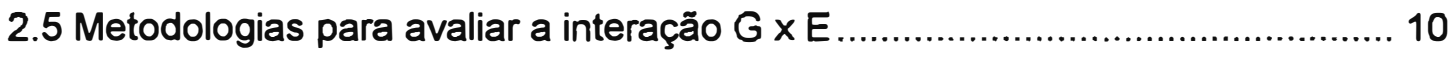

2.6 Interação G x E em soja ........................................................................ 11

2.7 Interação $G$ x E e ciclos de maturação em soja ......................................... 13

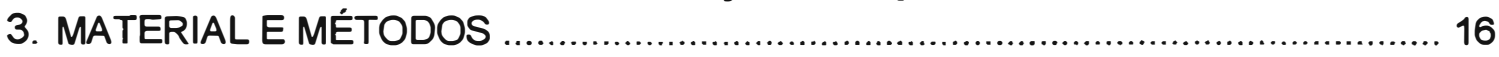

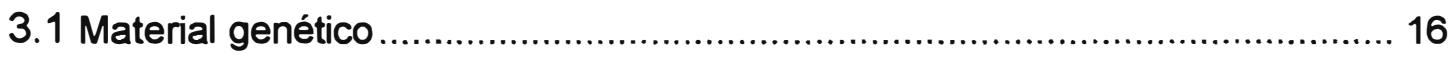

3.2 Ambientes de condução dos experimentos ........................................ 18

3.3 Procedimentos experimentais .......................................................... 19

3.4 Caracteres avaliados ..................................................................... 20

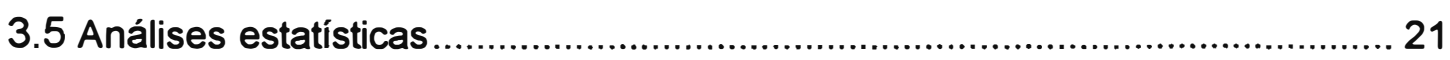

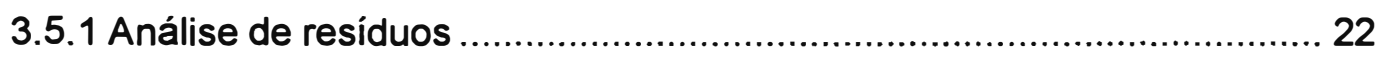

3.5.2 Análises de variâncias .............................................................. 23

3.5.2.1 Análise de variância para as testemunhas .......................... 23

3.5.2.2 Análise de variância para as linhagens experimentais ............ 25

3.5.3 Análise de médias ................................................................. 27

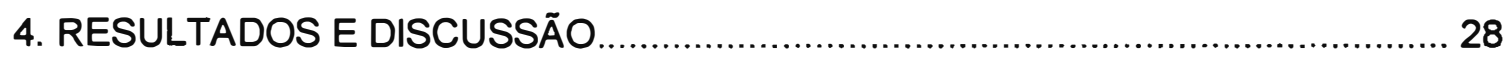

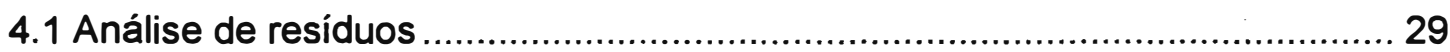

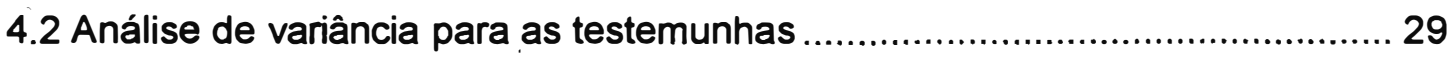

4.3 Análise de variância para as linhagens experimentais .............................. 30

4.3.1 Análises individuais.............................................................. 30

4.3.2 Análises conjuntas .............................................................. 32

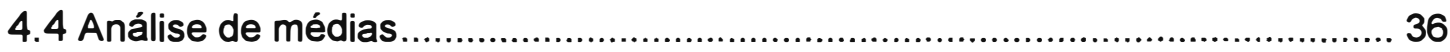

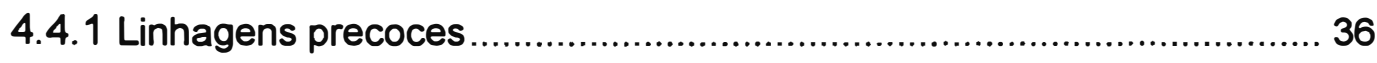

4.4.2 Linhagens semi-precoces .................................................. 37

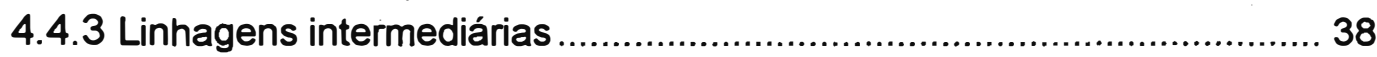

4.4.4 Linhagens semi-tardias ...................................................... 38

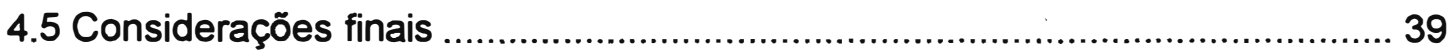

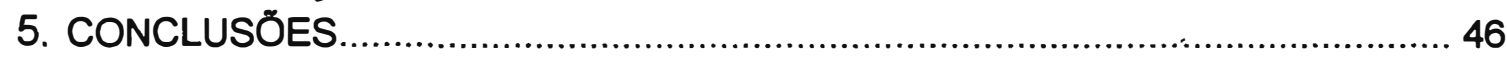

REFERÊNCIAS BIBLIOGRÁFICAS .................................................... 48

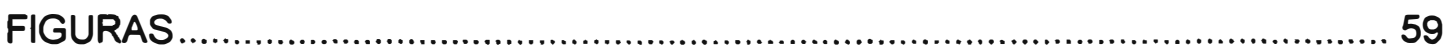

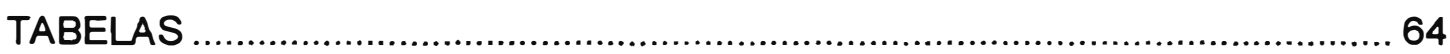

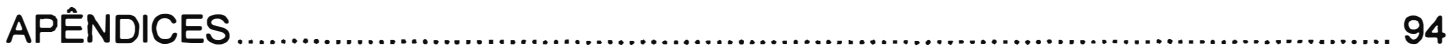




\section{INTERAÇÃO GENÓTIPOS $\times$ LOCAIS EM LINHAGENS \\ EXPERIMENTAIS DE SOJA COM DIFERENTES \\ CICLOS DE MATURAÇÃO}

Autor: Maurisrael de Moura Rocha

Orientador: Natal Antonio Vello

\section{RESUMO}

Foram avaliadas 188 linhagens experimentais de soja [G/ycine $\max ($ L.) Merrill] pertencentes a quatro ciclos de maturação (precoce, semiprecoce, intermediário e semi-tardio) com o objetivo de pesquisar a magnitudé da interação genótipos $\times$ locais. Estas linhagens têm sigla USP e foram desenvolvidas no primeiro ciclo de recombinação envolvendo cruzamentos biparentais (adaptados e semi-exóticos) dos programas de seleção recorrente para produtividade de grãos e óleo, atualmente em desenvolvimento no Setor de Genética Aplicada às Espécies Autógamas, Departamento de Genética, Escola Superior de Agricultura "Luiz de Queiroz" (ESALQ), Universidade de São Paulo (USP).

Os experimentos foram conduzidos em três localidades do município de Piracicaba, SP, Brasil (Anhembi, Areão e ESALQ), com 22³9'00" de longitude Oeste e a uma altitude média de $540 \mathrm{~m}$. A semeadura das linhagens experimentais ocorreu na época normal de cultivo para o Estado de São Paulo (cultivo de verão), mês de novembro, safra 96/97. Em cada local foram avaliados quatro experimentos, correspondentes a quatro ciclos de maturação. O delineamento utilizado foi 0 de blocos ao acaso com duas repetições. Cada repetição foi estratificada em conjuntos experimentais com 
quatro testemunhas comuns, diferindo para cada ciclo de maturação (CM). A parcela experimental foi representada por quatro fileiras de 5 metros de comprimento, espaçadas de 0,5 metro $\left(10 \mathrm{~m}^{2}\right)$. A área útil utilizada para a tomada de dados compreendeu apenas as duas fileiras centrais da parcela $\left(4,0 \mathrm{~m}^{2}\right)$, eliminando-se 0,5 metro de cada extremidade. Os caracteres avaliados foram: número de dias para a maturidade (NDM), altura de planta na maturidade (APM), acamamento (Ac), valor agronômico (VA), produtividade de grãos (PG), porcentagem de óleo nas sementes (\%OL), produtividade de óleo (PO) e reação ao cancro da haste da soja (CHS, Diaporthe phaseolorum f. sp. meridionalis Morgan-Jones).

As análises individuais revelaram a existência de variabilidade para todos os caracteres nas linhagens semi-precoces (LSP), sendo observado ausência de diferenças para \%OL nas linhagens precoces (LP), intermediárias (LI) e semi-tardias (LST). A análise do coeficiente de variação experimental (CV\%) mostrou que NDM e \%OL foram menos influenciados pelo ambiente, enquanto PG e PO, foram mais influenciados.

A significância da interação $G \times L$ para a maioria dos caracteres evidencia um comportamento diferencial das linhagens quando submetidas aos diferentes locais de teste. No entanto, observou-se ausência de interação para $\% O L$ (LP e LI) e Ac (LI), permitindo maior previsibilidade desses caracteres nesses $\mathrm{CM}$, quando submetidos a diferentes ambientes. $O$ local Anhembi foi superior permitindo as linhagens expressarem melhor o seu potencial genético; - local Areão contribuiu negativamente para a expressão dos caracteres. As linhagens mais produtivas representam todos os $\mathrm{CM}$, com superioridade para as LI; as LP e LST foram as mais estáveis e instáveis ao CHS, respectivamente. Maior variabilidade entre linhagens dentro de $\mathrm{CM}$ foi observada para os caracteres APM, PG, VA e PO. Isto indica maior probabilidade de ganhos com a seleção para esses caracteres. 
As melhores linhagens pertencem aos dois programas (produtividade de grãos e óleo), confirmando a possibilidade de obter ganhos simultâneos com a seleção para PG e PO, nos dois programas. Essas linhagens são resultantes de cruzamentos adaptado $x$ adaptado e adaptado $x$ exótico. Isto indica que é possível obter genótipos superiores a partir de cruzamentos com $50 \%$ de parentais exóticos, previamente selecionados para à região de cultivo. As seguintes linhagens USP destacaram-se com valores superiores para PG, VA, Ac, \%O, PO e baixa ou nenhuma reação ao CHS: 935243, 93-2316, 94-1086, 93-5513, 93-5582, 93-5539, 93-5082, 94-1070, 931203 e 93-2479. 


\title{
GENOTYPE $\times$ LOCATION INTERACTION IN SOYBEAN EXPERIMENTAL LINES WITH DIFFERENT MATURITY CICLES
}

\author{
Author: Maurisrael de Moura Rocha \\ Adviser: Prof. Dr. Natal Antonio Vello
}

\section{SUMMARY}

A total of 188 soybean [Glycine max (L.) Merrill] experimental lines divided in four maturity cicles (early, semi-early, intermediate and semi-late) were avaluated with the objective to estimate the magnitude of the genotype $x$ location $(G \times L)$ interaction. The lines were developed in the first recombination cycle of the recurrent selection program for seed and oil yield, from different biparental crosses between adapted (adapted $x$ adapted) and mixed (adapted $x$ exotic) parents. This program is coordinated by Genetic Department, Faculty of Agriculture "Luiz de Queiroz" (ESALQ), University of São Paulo (USP).

The experiments were carried out at three localities (Anhembi, Areão and ESALQ) Piracicaba, State of São Paulo, Brazil, at $22^{\circ} 39^{\prime} 00^{\prime \prime}$ south latitude and $540 \mathrm{~m}$ of altitude in average. The sown of the lines occured in november, 1996, corresponding to summer crop (normal crop season in State of São Paulo). Separate evaluations were conducted for each maturity cicle, within each locality, in randomized complete block designs, with two replications. Each block was stratified in experimental sets with four common cheks differing for each maturity cicle. Experimental plot consisted of four rows $5 \mathrm{~m}$ long and 0.50 $\mathrm{cm}$ apart. The characters evaluated were: Number of days to maturity (NDM), plant height at maturity (APM), lodging (Ac), agronomic value (VA), seed yield (PG), seed oil content (\%OL), oil yield (PO) and reaction to the soybean stem canker (CHS, Diaporthe phaseolorum f. sp. Meridionalis Morgan-Jones). 
Individual analysis showed significative variability in all characters for semi-early lines. It was observed not significant difference only in relation to $\% \mathrm{OL}$ and $\mathrm{Ac}$ characters for the early, intermediate and semi-late lines. The analysis of the experimental variation coefficient indicated that NDM and \%OL were less influenced by environment, while $P G$ and $P O$ were more affected.

The $G \times L$ interaction was highly significant $(P<0,01)$ for most characters in all maturity cicles, indicating that the lines had a differential behavior at the three localities. However, it was observed absence of $G \times L$ interaction for \%OL (early and intermediate lines) and Ac (intermediate lines), allows to predict the performance of these characters for differents environments.

The means analysis showed that Anhembi was the superior locality, contributing for a better express of the genetic lines potential, specially in relation to PG and PO. In the other hand, expression characters was lower at Areão locality for all maturity cicles. Intermediate lines were the most productive; early and semi-late lines were more and less stable in relation to CHS, respectively. The characters that showed larger variability among lines were: APM, VA, PG and PO, indicating that is larger the probability of success with selection for these characters.

The both breeding programs, for to increase PG and PO, were able to develop superior lines. It was observed that these lines were originated from adapted and mixed crosses. This is an evidence that is possible to obtain superior genotypes from crosses with $50 \%$ of exotic parents, since they were previously selected to adaptation to the enviroment of crop region. The USP lines with superior performance for $\mathrm{PG}, \mathrm{VA}, \mathrm{Ac}, \% \mathrm{OL}, \mathrm{PO}$ and $\mathrm{CHS}$ characters were 93-5243, 93-2316, 94-1086, 93-5513, 93-5582, 93-5539, 93-5082, 94$1070,93-1203$ e 93-2479. 


\section{INTRODUÇÃO}

A soja (Glycine max (L.) Merrill) representa uma cultura de grande interesse econômico, graças à qualidade nutricional de seus grãos, dada pelos conteúdos elevados de proteína $(40 \%)$ e óleo $(20 \%)$, assim como, pela sua elevada produtividade de grãos.

Atualmente, no Brasil, a soja é cultivada numa considerável diversidade de ambientes, desde as altas latitudes (Sudeste e Sul) até as baixas latitudes equatoriais-tropicais (Centro-Oeste e Nordeste). Neste sentido, a seleção de genótipos com elevados teores de proteína e óleo, alta produtividade e capacidade de adaptação a uma ampla faixa de ambientes é um dos principais objetivos dos programas de melhoramento genético. Assim, por representarem caracteres cuja variação é contínua (caracteres quantitativos), suas expressões fenotípicas resultam não só dos efeitos genotípicos (G), mas também dos efeitos ambientais $(E)$ e das interações genótipos $\mathrm{x}$ ambientes $(\mathrm{G} \times \mathrm{E})$.

A interação $G \times E$ é um componente da variação fenotípica resultante do comportamento diferencial apresentado pelos genótipos, quando submetidos a mais de um ambiente. Sua magnitude na expressão fenotípica do caráter pode reduzir a correlação entre fenótipo e genótipo, inflacionando a 
variância genética e, por sua vez, parâmetros dependentes desta, como herdabilidade e ganho genético com a seleção.

O conhecimento das influências genéticas e ambientais sobre as variações fenotípicas observadas, têm importância em manter uma alta e constante produtividade agrícola. No entanto, nos programas de melhoramento a falta de recursos torna difícil a avaliação de um grande número de linhagens experimentais através de ensaios multilocais para o teste dos efeitos da interação $G \times E$. Por esta razão, os melhoristas têm informações escassas sobre a variação atribuivel às diferentes respostas dos genótipos quando cultivados em condições ambientais diferentes (Soldini, 1993).

A obtenção de linhagens com pequena ou nenhuma influência da interação $G \times E$ em diferentes ciclos de maturação, torna-se de grande importância, pois pode fornecer informações sobre suas estabilidades, tendo em vista a busca contínua de maior regularidade na produtividade de grãos por parte dos agricultores. Além, disso, ajuda no melhor planejamento das épocas de semeadura e colheita, fazendo com que o produtor enfrente com maior probabilidade de sucesso, as variações do ambiente (doenças e pragas, pluviosidades excessivas, secas, geadas, efeitos pronunciados do fotoperíodo, etc.).

Este estudo é parte do programa de melhoramento genético de soja iniciado em 1983 no Departamento de genética da Escola Superior de Agricultura "Luiz de Queiroz" da Universidade de São Paulo. O programa visa, por meio da seleção recorrente e utilização de germoplasma exótico, a ampliação da base genética da soja e o aumento das produtividades de grãos e óleo. A pesquisa desenvolvida nesta dissertação tem por objetivo principal avaliar a magnitude da interação genótipos $x$ locais em linhagens experimentais de soja, envolvendo quatro ciclos de maturação (precoce, semiprecoce, intermediário e semi-tardio). 


\section{REVISÃO DE LITERATURA}

\subsection{Taxonomia, origem e citogenética da soja}

A soja é uma espécie anual de auto-polinização, pertencente à família Leguminosae, subfamília Faboideae, tribo Phaseoleae, subtribo Phaseolinae, gênero Glycine, subgênero soja e espécie Glycine max (L.) Merrill. Evidências históricas e geográficas indicam que foi domesticada no século XI d.C, no Nordeste da China, e que seu provável lugar de origem seja o Vale do Rio Amarelo ( $X u$ et al., 1989). Apresenta $2 n=40$ cromossomos, representando um tetraplóide diploidizado (Van Raamsdonk, 1995), ou seja, um poliplóide que se comporta citologicamente como um diplóide (Hymowitz et al., 1997).

\subsection{Expansão e importância sócio-econômica da soja}

A soja foi levada da China e introduzida nos Estados Unidos em 1765. No Brasil, sua introdução iniciou-se pela Bahia, passando por CampinasSP, em 1892, e chegando ao Rio Grande do Sul em 1900. A partir dessa época ela se expandiu para outros estados do Sul do Brasil, sendo que no Paraná, sua produção passou de $8 \%$, em 1965 , para $42 \%$ do total nacional, em 1976 . A partir desse ano o Rio Grande do Sul e o Paraná tiveram praticamente a mesma contribuição no total da soja produzida no Brasil. Dados mais recentes (1986-1990) indicam que além desses dois estados, Mato Grosso e Mato 
Grosso do Sul têm contribuído com $15 \%$ e 13\%, respectivamente, para a produção brasileira de soja (Costa, 1996). Novas fronteiras de cultivo estão sendo abertas em regiões do cerrado brasileiro com grandes possibilidades de expansão, como é o caso das regiões Norte e Nordeste, destacando-se os Estados de Rondônia, Tocantins, Bahia, Maranhão e Piauí.

Em termos mundiais, o maior produtor de grãos e óleo de soja são os Estados Unidos, com previsão de 74 e 7,5 milhões de toneladas, respectivamente, para a safra 1997/98. O Brasil representa o segundo produtor, com previsão de 29,7 milhões de toneladas de grãos para a safra 1997/98. Os Estados do Paraná, Rio Grande do Sul e Mato Grosso lideram a produção nacional com 7; 6,3 e 6 milhões de toneladas de grãos, respectivamente (AGRIANUAL, 1998).

Entre as leguminosas, a soja destaca-se pelo seu enorme valor sócio-econômico, resultado da alta composição em proteína $(40 \%)$ e óleo (20\%) nas sementes, da alta produtividade de grãos (cerca de $2 t / h a$ ) e da presença de genes adaptativos a todos os tipos de ambientes de cultivo. Estas características a tornam uma das culturas mais importantes mundialmente.

\subsection{Melhoramento genético da soja}

Segundo Vello (1992), o melhoramento da soja pode ser considerado um programa de quatro fases. A primeira fase é representada pela introdução de genótipos e foi iniciada no final do século passado. A segunda fase compreende cruzamentos simples entre dois parentais (cruzamentos biparentais), tendo se iniciado na década de 40. A terceira fase envolve cruzamentos múltiplos entre oito ou mais parentais, com início na década de 70. A quarta fase relaciona-se à biotecnologia (marcadores moleculares, transformação de plantas, etc.), com início na década de 80 . Hoje, todas as quatro fases continuam em andamento, de maneira sobreposta, com grande 
predominância dos cruzamentos biparentais. No Brasil, atualmente tem-se utilizado cruzamentos múltiplos em programas de seleção recorrente com o objetivo de ampliar a base genética do germoplasma cultivado e, ao mesmo tempo, promover o desenvolvimento de novos cultivares.

Os principais objetivos no melhoramento da soja têm sido o aumento da produtividade, período juvenil longo (menor sensibilidade ao fotoperíodo), resistência às principais pragas (lagartas da soja, percevejos, etc.) e doenças (mancha olho-de-rã, cancro-da-haste da soja, nematóides do cisto e galhas, etc.), boa qualidade fisiológica de sementes e tolerância ao complexo de acidez do solo. Esses últimos, contribuem decisivamente para uma maior estabilidade da produção e adaptabilidade dos novos cultivares a diferentes regiões de cultivo, diminuindo assim, os efeitos da interação $G \times E$. Um outro objetivo seria a melhoria na qualidade da soja como alimento (Almeida \& Kiihl, 1998).

\subsection{Aspectos da interação genótipos $x$ ambientes ( $\mathrm{G}$ E)}

Segundo Allard (1971), após Johannsen ter demonstrado a distinção entre genótipo e fenótipo, ficou bem claro que a variação se origina da ação conjunta do genótipo, do ambiente e da interação entre o genótipo e o ambiente (interação $G \times E$ ). Esse último componente reflete as diferentes sensibilidades dos genótipos às variações do ambiente (Jinks \& Pooni, 1988; Falconer \& Mackay, 1996), resultando em mudanças no desempenho relativo dos genótipos, quando submetidos a diferentes ambientes (Fehr, 1987).

Falconer (1989) afirma que as interações $G \times E$ podem surgir por duas razões: (a) por diferentes respostas de igual conjunto gênico em diferentes ambientes; e (b) pela expressão de diferentes conjuntos gênicos em diferentes ambientes (Cockerham, 1963). Quando um mesmo conjunto de genes se expressa em diferentes ambientes, as diferenças nas respostas 
podem ser explicadas pela heterogeneidade das variâncias genéticas e experimentais ou por ambas; e, quando diferentes conjuntos de genes se expressam em ambientes distintos, as diferenças nas respostas explicam-se por uma inconsistência das correlações genéticas entre os valores de um mesmo caráter em dois ambientes. Vello (1986) comenta que a composição alélica pode influenciar a estabilidade fenotípica dos cultivares. Os híbridos, por serem altamente heterozigóticos, são considerados mais estáveis do que os genótipos homozigóticos.

Estatisticamente, interações $\mathrm{G} \times \mathrm{E}$ são detectadas como um padrão de resposta diferencial e significante dos genótipos, entre ambientes. Biologicamente isto ocorre quando as contribuições (ou nível de expressão) dos genes regulando o caráter, diferem entre ambientes. Essa contribuição dos genes para a expressão de um caráter é considerada ser a base biológica das interações $G \times E$ detectadas pelos testes estatísticos (Basford \& Cooper, 1998). De uma outra forma, as causas da interação $G \times E$ têm sido atribuídas a fatores fisiológicos e bioquímicos próprios de cada genótipo cultivado (Cruz \& Regazzi, 1994).

Segundo Romagosa \& Fox (1993), o ambiente é um termo geral que inclui uma série de condições sob as quais as plantas crescem, podendo envolver locais, anos, práticas culturais ou de manejo, ou a combinação de todos esses fatores. Comumente cada local e ano é considerado como um ambiente diferente.

Allard \& Bradshaw (1964) classificaram as variáveis ambientais em dois grupos: previsíveis e imprevisíveis. As variáveis previsíveis seriam as características gerais de clima e solos e aquelas que ocorrem de maneira sistemática (comprimento do dia, grau de insolação, etc.) ou estão sob controle humano (tipo de solo, época de semeadura, espaçamento entre fileiras, densidade de semeadura, taxas de aplicação de nutrientes, etc.). Por outro lado, as variáveis imprevisíveis caracterizam-se por flutuar inconsistentemente 
e incluem precipitações, temperatura, umidade relativa e eventos climáticos como geadas, granizo, etc. Segundo Fehr (1987), as variáveis imprevisiveis são as que mais contribuem para as interações genótipos $x$ locais, genótipos $x$ anos e genótipos $\mathrm{x}$ locais $\mathrm{x}$ anos.

Comstock (1996) subdivide ambientes em micro e macroambientes; microambiente corresponde ao ambiente total de uma simples planta ou animal, enquanto macroambiente representa o ambiente geral associado com um local, um período de tempo, etc. No microambiente incluemse as características físicas e químicas do solo, variáveis climáticas (temperatura, umidade, quantidade e qualidade da radiação solar, etc.) e o número e tipo de organismos biológicos (patógenos, insetos, etc.) aos quais as plantas são expostas. O macroambiente engloba a população de microambientes pertinentes a uma população de alguns genótipos ou plantas, delineados em termos de espaço, tempo e práticas agrícolas.

Segundo Johnson et al. (1955), a variância da interação $G \times E$ indica a variabilidade no desempenho relativo dos genótipos em diferentes ambientes e sua magnitude em comparação com a variância genética para vários caracteres e diferentes populações. Isto determina a necessidade de repetições em locais, anos e testes individuais, na estimação precisa de médias sobre as quais a seleção é baseada. Em estudo envolvendo duas populações de soja, avaliadas em diferentes locais e anos, os autores evidenciaram que, a variabilidade genética para dados de produtividade de grãos em um local e um ano, foi reduzida em $71 \%$ quando comparada ao desempenho médio baseado em todos os locais e anos. Isto prova que a interação $\mathrm{G} \times \mathrm{E}$ diminui a correlação entre valores genotípicos e fenotípicos $\mathrm{e}$, posteriormente, a resposta à seleção (Comstock \& Moll, 1963).

Quando os testes de avaliação dos genótipos são conduzidos em um só ambiente, a variância genética pode ficar superestimada, ou seja, pode conter componentes da interação $\mathrm{G} \times \mathrm{E}$. Isto traz implicações muito importantes 
para o melhoramento de plantas, pois vários parâmetros genéticos podem ser estimados de forma errônea, tais como: a herdabilidade, já que é definida como o quociente entre as variâncias genética e fenotípica; o ganho esperado com a seleção, pois o progresso esperado é diretamente proporcional à herdabilidade (Takeda, 1990).

Burton (1997), enfatizando os meios para melhorar a eficiência dos métodos de melhoramento e a taxa de melhoramento da soja, inclui entre eles, o desenvolvimento de métodos para manejar as interações $G \times E$ de forma que as herdabilidades para produtividade sejam aumentadas.

Vencovsky \& Barriga (1992) relatam que não basta apenas detectar a presença de interações, deve-se também considerar a sua natureza. Assim, a interação $G \times E$ pode ser simples (não causa mudanças na classificação dos genótipos entre ambientes) e complexa (quando altera a classificação dos genótipos entre ambientes). A interação simples indica a presença de genótipos adaptados a uma ampla faixa de ambientes. Assim, a recomendação de cultivares pode ser feita de forma generalizada. A interação complexa indica a presença de materiais adaptados a ambientes particulares. Isto traz uma complicação para o melhorista uma vez que a recomendação é restrita a ambientes específicos (Ramalho et al., 1993). Então, a interação relacionada à parte simples é proporcionada pela diferença de variabilidade entre genótipos nos ambientes, enquanto que a interação complexa, pela falta de correlação nos desempenhos médios dos genótipos entre ambientes (Cruz \& Castoldi, 1991).

Estudos a respeito da interação $\mathrm{G} \times \mathrm{E}$, apesar de serem de grande importância para $\circ$ melhoramento, não proporcionam informações pormenorizadas sobre o comportamento de cada genótipo frente às variações ambientais. Para tal objetivo, realizam-se análises de adaptabilidade e estabilidade, pelas quais se torna possível a identificação de cultivares com 
comportamento previsível e que sejam responsivos às variações ambientais, em condições específicas ou amplas (Cruz \& Regazzi, 1994).

Segundo Vencovsky \& Barriga (1992), adaptação e estabilidade, embora sejam fenômenos relacionados, não devem ser considerados como um só. Mariotti et al: (1976), designam adaptabilidade como a capacidade potencial dos genótipos de responderam vantajosamente ao estímulo ambiental. A estabilidade, por outro lado, seria a capacidade dos genótipos de exibirem um desempenho o mais constante possível, em função de variações na qualidade ambiental. Cruz \& Regazzi (1994) conceituam adaptabilidade da mesma forma e comentam que estabilidade refere-se à capacidade de os genótipos mostrarem um comportamento altamente previsivel em função do estímulo ambiental.

Becker \& Léon (1988) comentam que as interações $G \times E$ podem ser parcialmente entendidas como um resultado de uma reação diferencial a fatores de estresses ambientais como secas ou doenças e, consequentemente, o melhoramento da resistência é de importância para melhorar a estabilidade de produção. Kang \& Magari (1996) corroboram esse argumento comentando que a estabilidade de produção depende de seus componentes e de outros caracteres, tais como: resistência a pragas, tolerância a fatores de estresses e variáveis ambientais (todas contribuem de forma diferente para a interação $G \times$ E). Se a importância relativa desses componentes foi avaliada e um ou mais fatores limitantes é ou são determinados, então, sua manipulação pode aumentar a estabilidade.

Atualmente, a interação $G \times E$ tem ganhado importância até mesmo em estudos sobre o uso de marcadores moleculares para identificação e manipulação de segmentos específicos, controlando caracteres quantitativos (QTL's). Os efeitos dessa interação e repetibilidades das populações em estudo, envolvendo esses marcadores, têm sido investigados em programas de melhoramento que se utilizam dessa técnica biotecnológica. Alguns autores 
têm estudado a interação de QTL's com ambientes. Os resultados têm evidenciado casos de baixa e alta significância para a interação QTL's $x$ ambientes. Essas diferenças podem ser função do caráter estudado e dos métodos utilizados para identificar tal interação (Dudley, 1993).

\subsection{Metodologias para avaliar a interação G x E}

Diversos métodos têm sido propostos para investigar a interação

G X E. A diferença entre eles origina-se nos próprios conceitos e procedimentos biométricos para medir a interação.

Métodos mais simples utilizam a análise comum de variância (ANAVA), através da análise conjunta de experimentos. A magnitude das interações $G \times E$ é determinada através do uso de um teste de hipótese, normalmente o teste $F$. Destacam-se, ainda, métodos que procuram identificar os genótipos que menos contribuem para a interação $G \times E$ (genótipos estáveis) e que poderiam ser recomendados para todo o grupo de ambientes. Nesta categoria estão os procedimentos de regressão linear simples (Finlay \& Wilkinson, 1963; Eberhart \& Russell, 1966, etc.), quadrática (Brasil, 1990) e múltipla (Verma et al., 1978; Silva \& Barreto, 1985; Cruz et al., 1989, etc.); modelos não lineares (Chaves et al., 1989; Toler, 1990, etc.) e não paramétricos, como a ordem ou "ranks" (Huhn, 1996); e métodos multivariados, como distâncias genéticas (Hanson, 1994; Monelli, 1996) e o modelo AMMI (Additive Main effects and Multiplicative Interaction analysis), sugerido por Gauch Junior \& Zobel, 1996. 


\subsection{Interação G x E em soja}

Segundo Câmara (1998), o desenvolvimento normal da planta de soja depende de vários fatores, dentre eles destacam-se: intensidade da radiação solar (relacionada com a atividade fotossintética, ao alongamento da haste principal e das ramificações, à expansão foliar, à nodulação, etc.), duração da radiação solar (fotoperíodo), temperatura, umidade (disponibilidade de água) e tratos culturais (manejo). Tais fatores podem influir diferentemente entre os locais e anos de cultivo, contribuindo para as interações $\mathrm{G} \times \mathrm{E}$.

Outros fatores têm contribuído em maior ou menor escala para as interações $\mathrm{G} \times \mathrm{E}$. Dentre eles, as doenças se destacam como um dos fatores bióticos que mais têm influído no comportamento diferencial dos genótipos de soja entre ambientes. Como exemplo, pode-se citar o cancro da haste da soja (CHS) causado pelo fungo Diaporthe phaseolorum f.sp. meridionalis MorganJones. No Brasil, devido ao grande aumento dos prejuízos por essa doença, torna-se urgente o melhoramento genético para criação de novos cultivares resistentes e com alta produtividade de grãos (Hiromoto, 1996). Cultivares resistentes já estão disponíveis no mercado, mas Yorinori (1998) estima que para a safra 1997/98, algumas lavouras do Maranhão, Piauí, Rio Grande do Sul e áreas novas de Rondônia poderão ser afetadas devido ao uso de cultivares suscetíveis. Atualmente, a avaliação dos genótipos quanto a reação ao $\mathrm{CHS}$, é condição indispensável em programas de melhoramento genético de soja.

A interação $G \times E$ em soja tem sido muito estudada pelos melhoristas, com diversas finalidades, tais como: efeitos envolvendo genótipos x locais (Soldini, 1993; Shimoya, 1987; etc.), genótipo $x$ locais $x$ regiōes (Pfeiffer et al., 1995, etc.), genótipos $x$ anos (Billore \& Joshi, 1997; Gieco, 1997; etc.), genótipos $x$ locais $x$ anos (Bonato, 1978; Batitucci, 1990; Toledo et al., 1990; Alliprandini, 1992; Alliprandini et al., 1993; Alliprandini et al., 1994; Sneller, 1997; Cober et al., 1997, etc.), genótipos x épocas de semeadura 
(Dutra, 1986; Moraes et al., 1997; Raut et al., 1997, etc.), genótipos $x$ anos $x$ épocas de semeadura (Bhering, 1989; Galvão, 1994; etc.) e genótipos $x$ locais $X$ anos $x$ épocas de semeadura (Arantes, 1979; Oliveira, 1990; Akhter \& Sneller, 1996, etc.).

Os estudos envolvendo interação genótipos $x$ épocas de semeadura têm sido feitos mais com o objetivo de verificar a sensibilidade dos genótipos de soja ao fotoperíodo. Farias Neto (1987), Nass (1989) e Moreira (1992), estudando tais efeitos, identificaram genótipos com tolerância ao fotoperíodo, que podem ser cultivados no período outono-inverno, assim como em regiões de baixas latitudes como as regiões Norte e Nordeste do Brasil. Tomkins \& Shipe (1997), estudando o comportamento de genótipos com período juvenil longo, também identificaram genótipos com superioridade de adaptação fenotípica a diferentes épocas de semeadura.

A análise da interação genótipos $x$ locais objetiva, principalmente, pesquisar o comportamento dos genótipos frente aos fatores previsíveis, micro (dentro de locais) e macroambientais (entre locais), no espaço. Soldini (1993) estudando linhagens e cultivares de soja, em três locais, verificou variabilidade entre locais e comportamento diferencial dos genótipos.

0 efeito de anos é caracterizado como um fator imprevisível. A avaliação das interações genótipos $x$ anos são de suma importância, pois fornece informação sobre a previsibilidade do comportamento dos genótipos frente aos fatores ambientais, no tempo. Vencovsky \& Torres (1988), estudando estabilidade, em milho, ao nível geográfico (estabilidade espacial ou adaptabilidade) e ao nível de tempo (estabilidade temporal), enfatizam que, para o produtor rural, é mais importante que um cultivar seja estável ao longo dos anos. Gieco (1997), estudando o efeito de anos em três populações de soja, conclui que a seleção baseada na média de três anos foi mais eficiente que a seleção praticada em um determinado ano. Também comenta que a aplicação de altas intensidades de seleção, em um determinado ano, pode 
representar a perda de muitos genótipos promissores. Triller \& Toledo (1996), estudando a predição de cruzamentos em geração $F_{3}$, enfatizaram que na presença de interação $\mathrm{G} \times \mathrm{E}$, o uso de dados de mais de um ano foi útil para aumentar a precisão das estimativas para o caráter produtividade de grãos.

\subsection{Interação G x E e ciclos de maturação em soja}

Vello (1992) menciona que a precocidade é um dos principais caracteres considerados no melhoramento das espécies produtoras de grãos como a soja. Especialmente devido à grande demanda por cultivares precoces para atender ao novo sistema agrícola de dois cultivos por ano ou cinco cultivos em dois anos consecutivos. O grupo semi-precoce é o mais importante para a agricultura paulista, pois a maioria dos plantios envolve cultivares que têm entre 120 e 135 dias de ciclo. Os genótipos dos grupos semi-tardio e tardio também são importantes e, geralmente, têm alta produtividade de grãos, consequência da correlação positiva entre ciclo e produtividade. Estes dois últimos grupos reúnem os genótipos mais apropriados para a safrinha no Estado de São Paulo, com plantio atrasado para o período de janeiro a março.

Segundo Alliprandini et al. (1993), o grupo de maturação médio, embora seja produtivo, não tem grande aceitação por parte dos agricultores, pois permanecem maior período de tempo no campo, sendo preferido os ciclos precoce e semi-precoce. Tendo em vista tal evidência, os programas de melhoramento tem dedicado maior esforço na obtenção de linhagens desses dois últimos ciclos.

Kang et al. (1989) estudaram a contribuição de algumas variáveis (índice ambiental, pluviosidade, temperaturas máxima e mínima, e umidade relativa) para a interação $G \times E$, englobando diferentes grupos de maturação em soja. Os autores comentam que cultivares pertencentes a grupos de maturação distintos possuem diferentes estádios de desenvolvimento 
fisiológico, interagindo com o ambiente em um tempo particular. Portanto, espera-se que os componentes da interação $G \times E$ sejam diferentes para cada grupo de maturação. Eles concluíram que os grupos de maturação foram mais afetados por fertilidade diferencial de solos e/ou práticas culturais do que por fatores do tempo.

Uphoff et al. (1997), estudando o ganho genético para produtividade de grãos por três métodos de seleção recorrente, em soja, também separam os genótipos em classes de maturação semelhantes (precoce, médio e tardio). Os autores concluíram que a seleção para este caráter não teve influência negativa sobre a maturação e que a seleção de parentais dentro de um amplo intervalo de variação preveniu apreciáveis mudanças em dias para a maturidade entre os ciclos de seleção.

No Brasil, o estudo da interação $G \times E$ envolvendo diferentes ciclos de maturação, em soja, tem sido pouco explorado. No entanto, alguns trabalhos podem ser encontrados na literatura, a saber: Toledo et al. (1990), Alliprandini et al. (1993), Alliprandini et al. (1994), Soldini, (1993), Duarte et al. (1994) e Laínez-Mejía (1996).

A importância do agrupamento de genótipos dentro de ciclos de maturação em soja, no Brasil, foi primeiramente relatada por Arantes (1979). Alliprandini et al. (1993) confirmam tal importância, estudando três ciclos de maturação (precoce, semi-precoce e médio). Esses autores identificaram efeitos significativos entre ciclos de maturação. Isto indica que os ciclos são variáveis quanto ao comportamento dos genótipos que os integram. A interação significativa para ciclo de maturação $x$ locais $x$ anos indica que, para uma determinada combinação entre ano e local, existe um ciclo de maturação com maior produtividade. Esta informação é também de grande importância prática, pois os dados indicaram que o uso de cultivares de diferentes ciclos de maturação deve trazer regularidades na produção anual. 
Soldini (1993) e Laínez-Mejia (1996), estudando o efeito das interações genótipos $\times$ locais $(G \times L)$, em diferentes ciclos de maturação (precoce, intermediário e tardio), encontraram significâncias para a interação dentro de ciclos de maturação e para a maioria dos caracteres estudados, exceto para porcentagem de óleo (\%OL), que apresentou baixa ou nula interação. Identificaram também que as linhagens tardias se comportaram como as mais produtivas e as intermediárias como mais estáveis.

Duarte et al. (1994) também identificaram significância para os efeitos de locais e interação $G \times L$ para os diferentes ciclos de maturação estudados. No entanto, Alliprandini et al. $(1993 ; 1994)$ encontraram efeitos não significativos para a interação $\mathrm{G} \times \mathrm{L}$ e G $\times \mathrm{A}$ (genótipos $\times$ anos). Em relação à ausência de interação $G \times A$, os autores concluem que, havendo a necessidade de abreviar o período de avaliação para apenas um ano, os testes devem ser conduzidos em diversos locais. 


\section{MATERIAL E MÉTODOS}

\subsection{Material genético}

No ano agrícola 1996/97 foram avaliadas 188 linhagens experimentais de soja, correspondentes a quatro ciclos de maturação (CM): linhagens precoces (LP), semi-precoces (LSP), intermediárias (LI) e semitardias (LST). O material pertence à coleção de germoplasma do Setor de Genética Aplicado às Espécies Autógamas, Departamento de Genética, Escola Superior de Agricultura "Luiz de Queiroz" (ESALQ), Universidade de São Paulo (USP).

Os quatro $\mathrm{CM}$ foram reagrupados após seleção praticada na safra 1995/96, englobando materiais provenientes dos programas produtividade de grãos e óleo. Utilizou-se como critério de reagrupamento os seguintes intervalos de número de dias para maturação: 112-119 (LP), 120-127 (LSP), 128-135 (LI) e 136-142 (LST). O grupo de genótipos foi composto por 43 LP $F_{12: 6 ;} 63$ LSP $\left(51 F_{8: 3}\right.$ e $\left.12 F_{12: 6}\right) ; 49 \mathrm{LI}\left(23 F_{8: 3}, 4 F_{10: 3}\right.$ e $\left.22 F_{12: 6}\right)$ e 33 LST (21 $F_{10: 3,} 8 F_{11: 6}$ e $\left.4 F_{12: 6}\right)$.

Estas linhagens receberam a sigla USP e foram desenvolvidas no primeiro ciclo de recombinação dos programas de seleção recorrente para produtividade de grãos e óleo, em desenvolvimento no Departamento de Genética da ESALQ/USP (Vello,1992). Estes programas têm como objetivo principal, aumentar a base genética da soja cultivada e os níveis de 
produtividade de grãos e óleo. Informações sobre a identificação, genealogia, geração de endogamia, ciclo de maturação e programa de origem das linhagens avaliadas, são mostrados na Tabela 1.

As 163 linhagens oriundas do programa produtividade de grãos foram obtidas a partir de cruzamentos biparentais envolvendo quatro dialelos compostos de dez parentais pertencentes ao mesmo CM, totalizando 40 parentais. Maiores informações sobre a geração $F_{2}$, método de condução das populações segregantes e avanço de gerações, podem ser obtidas nos trabalhos de Freire Filho (1988), Nass (1989), Krieger (1992), Moreira (1992), Carbonell (1995), Gomes (1995) e Azevedo Filho (1997).

As 25 linhagens advindas do programa produtividade de óleo foram também obtidas a partir de cruzamentos envolvendo 40 parentais, sendo $75 \%$ adaptados e $25 \%$ exóticos. $\mathrm{Na}$ obtenção de híbridos envolvendo dois parentais, utilizou-se um esquema em cadeia circulante, com a formação de duas cadeias de cruzamentos. A primeira (cadeia mista), com $50 \%$ de parentais adaptados e $50 \%$ exóticos e a segunda (cadeia adaptada), contendo todos os parentais adaptados. Detalhes sobre a geração $F_{2}$, método de condução das populações segregantes e avanço de gerações, podem ser obtidas nos trabalhos de Zimback (1992), Montaño-Velasco (1994), Farias Neto (1995) e Laínez-Mejía (1996).

Os parentais envolvidos nos cruzamentos foram selecionados mediante estudos de campo, realizados nas safras 1983/84 e 1984/85, baseando-se em características desejáveis como elevada produtividade de grãos e óleo nas sementes, tolerância às variações do fotoperíodo, resistência a doenças (cancro da haste, nematóide do cisto e olho-de-rã) e pela sua diversidade genética. Esta foi estimada pelos coeficientes de parentesco baseados em suas genealogias (Vello et al., 1988; Vello, 1992 e 1995).

Foram utilizadas quatro testemunhas para cada $\mathrm{CM}$, compreendendo cultivares adaptados, de boa produtividade e com resistência 
ao cancro da haste (CHS) variando de mediana a totalmente resistentes. Como testemunhas precoces utilizou-se os cultivares IAC-Foscarin-31, Primavera, FT-Cometa e FT-Guaíra; para as semi-precoces, FT-Iramaia, FT-10, FT-2000 e IAC-12; para as intermediárias, IAC-4, IAC-12, IAC-100 e Stwart; e para as semi-tardias, IAC-4, IAC-8, IAC-11 e Stwart. Assim, o cultivar IAC-12 foi testemunha comum para os $\mathrm{CM}$ semi-precoce e intermediário; e os cultivares IAC-4 e Stwart, para os CM intermediário e semi-tardio.

\subsection{Ambientes de condução dos experimentos}

Os experimentos foram conduzidos em três locais do município de Piracicaba, SP: Anhembi $\left(L_{1}\right)$, caracterizado por solo aluvial distrófico, textura médio-arenosa, relevo plano, situado na Estação Experimental de Anhembi, à cerca de $60 \mathrm{Km}$ da ESALQ/USP; Areão $\left(L_{2}\right)$, com solo do tipo podzólico vermelho-amarelo distrófico, textura médio-argilosa, relevo ondulado, situado na Fazenda Areão e distante 5Km da ESALQ/USP; e ESALQ $\left(L_{3}\right)$, com solo do tipo terra roxa estruturada, textura argilosa, relevo ondulado, situado na área experimental do Departamento de Genética da ESALQ/USP. Todos os campos experimentais são pertencentes à ESALQ/USP. Uma visão panorâmica dos locais de avaliação dos experimentos são apresentados nas Figuras 2, 3 e 4.

Piracicaba está situada a $22^{\circ} 42^{\prime} 30^{\prime \prime}$ de latitude Sul, $47^{\circ} 39^{\prime} 00^{\prime \prime}$ de longitude Oeste e a uma altitude de $540 \mathrm{~m}$ acima do nível do mar. No Apêndice 1 são apresentadas as informações referentes às temperaturas, umidades relativas médias, precipitação pluvial e fotoperíodo obtidos durante a fase de condução dos experimentos (dados fornecidos pelo Departamento de Física e Meteorologia da ESALQ/USP). Nos Apêndices $2 a$ e $2 b$ são mostrados os critérios utilizados para a interpretação de análises de solos para o Estado de São Paulo, segundo Malavolta et al. (1989) e as análises de solo relativas às áreas experimentais utilizadas nos três locais. 
O preparo do solo foi similar para os três locais e consistiu de uma aração e duas gradagens. A adubação foi feita no sulco, aplicando-se $25 \mathrm{~g}$ da fórmula 4-2O-2O (N-P $\left.\mathrm{P}_{2} \mathrm{O}_{5}-\mathrm{K}_{2} \mathrm{O}\right)$ por metro. $\mathrm{A}$ inoculação das sementes foi realizada usando-se inoculante comercial contendo cepas de Bradyrhizobium japonicum diluído em água $(800 \mathrm{~g} / 20 \mathrm{I})$. Foram realizadas irrigações por aspersão no início e final do ciclo. Controles de pragas (principalmente percevejos) e de ervas daninhas foram feitos com aplicações de inseticida e herbicida pós-emergente e ou capina, respectivamente, quando necessário.

\subsection{Procedimentos experimentais}

As semeaduras ocorreram na época normal de cultivo para o Estado de São Paulo (cultivo de verão), nas datas 06/11/96 (local $L_{3}$ ), 12/11/96 (local $L_{2}$ ) e 20/11/96 (local $L_{1}$ ). Em cada local foram conduzidos quatro experimentos, cada um correspondendo a um CM diferente. Utilizou-se o delineamento em blocos casualizados com duas repetições. Em cada repetição os tratamentos foram estratificados em conjuntos experimentais com testemunhas comuns ao mesmo CM (dois para os CMP e CMST; e três para os CMSP e CMI). Isso objetivou detectar possiveis diferenças que possam ocorrer dentro de cada repetição, considerando que ela contém um grande número de tratamentos.

A parcela experimental foi representada por quatro fileiras de 5 metros de comprimento, espaçadas de 0,5 metro $\left(10 \mathrm{~m}^{2}\right)$. A área útil, utilizada para a tomada de dados, compreendeu as duas fileiras centrais da parcela $\left(4,0 \mathrm{~m}^{2}\right)$, eliminando-se 0,5 metro de cada extremidade. 


\subsection{Caracteres avaliados}

Os seguintes caracteres foram avaliados em cada experimento:

r - Número de dias para a maturidade (NDM): avaliado no estádio $R_{\mathbf{8}}$ (escala de Fehr \& Caviness, 1977), compreendendo o período entre a data da semeadura e a data em que $50 \%$ das plantas da área útil se encontravam com $95 \%$ das vagens maduras, expresso em dias;

x - Altura de planta na maturidade (APM): avaliado no estádio $R_{8}$ e compreendeu a distância na haste principal entre o colo e a inserção da vagem mais distal, tomada como um valor médio obtido a partir da mensuração de duas plantas representativas de cada uma das fileiras da área útil da parcela, expressa em cm;

- Acamamento (Ac): Avaliado no estádio $R_{\mathbf{8}}$ através de uma escala de notas visuais, variando de 1 (todas as plantas eretas) a 5 (todas as plantas prostradas), com dados transformados em $\sqrt{x+0,5}$ antes da realização das análises estatísticas;

x - Valor agronômico (VA): avaliado no estádio $R_{8}$ através de uma escala de notas visuais, variando de 1 (plantas ruins) a 5 (plantas ótimas), representativa de um conjunto de caracteres visuais adaptativos: arquitetura da planta, quantidade de vagens cheias, vigor e sanidade da planta, debulha prematura de vagens, acamamento e retenção foliar na maturidade; com dados transformados em $\sqrt{x+0,5}$ antes da realização das análises estatísticas; 
- Produtividade de grãos (PG): efetuada através do peso dos grãos, após a colheita, trilhagem das plantas da parcela e secagem dos grãos (13\%), expressa em quilogramas por hectare $(\mathrm{kg} / \mathrm{ha})$;

- Porcentagem de óleo (\%OL): avaliado pela metodologia de espectometria de ressonância nuclear magnética (NMR), utilizando-se o aparelho de NMR desenvolvido pela EMBRAPA-UAPDIA-São Carlos, em convênio com a FINEP e o Departamento de Genética da ESALQ/USP. Foi usada uma amostra de sementes para cada tratamento com um peso variando entre 2,50 a 2,70 gramas. Detalhes sobre o uso e procedimentos de análise pelo aparelho de NMR foram reportados por Montaño-Velasco (1994);

- Produtividade de óleo (PO): caráter obtido pelo produto entre a produtividade de grãos por parcela e a porcentagem de óleo nas sementes, expresso em quilogramas por hectare $(\mathrm{kg} / \mathrm{ha})$;

- Reação ao cancro da haste da soja (CHS): caráter avaliado visualmente, em condições naturais de campo, através do nível de dano e porcentagem de sintomas na parcela, usando-se quatro classificações: alta reação (AR), média reação $(M R)$, baixa reação $(B R)$ e nenhuma reação $(N R)$ ao $\mathrm{CHS}$; observações tomadas somente nos locais Areão e ESALQ, que apresentaram infestações naturais do fungo.

\section{5 Análises estatísticas}

As análises estatísticas dos dados foram realizadas utilizando-se o procedimento GLM do programa SAS para computadores (SAS INSTITUTE INC., 1996). 


\subsubsection{Análise de resíduos}

Antes de proceder à análise de variância dos dados, realizou-se uma análise de seus resíduos para todos os caracteres, em cada CM. Com este procedimento pode-se avaliar a existência de dados discrepantes ("outliers"), a falta de homogeneidade de variâncias, o ajustamento dos erros à distribuição normal, bem como as suposições de independência dos erros e de aditividade no modelo matemático.

Com o objetivo de verificar a existência de "outliers" utilizou-se a análise gráfica envolvendo os resíduos padronizados e o valor ajustado (predito pelo modelo), para cada observação, como sugere Parente (1984). 0 resíduo padronizado $\left(d_{i j}\right)$ é calculado através da seguinte expressão:

$$
d_{i j}=\frac{e_{i j}}{\sqrt{\text { QMRes. }}}
$$

onde:

$e_{i j}$ : resíduo resultante do ajuste do modelo escolhido, dado por:

$$
e_{i j}=\left[Y_{i j}\left(\text { observado) }-Y_{i j} \text { (ajustado) }\right] \text {, com } Y_{i j} \text { (ajustado }\right)=\hat{m}+\hat{t}_{i}+\hat{b}_{j}
$$

QMRes.: quadrado médio do resíduo obtido na análise de variância para o referido modelo.

As análises de resíduos foram realizadas através do pacote estatístico S.A.S para computadores, utilizando-se o programa do Apêndice 3. Através da visualização gráfica, se identificada a presença de observações "outliers", estas são retiradas. Então, realiza-se novamente a análise de resíduos, agora substituindo-se as observações discrepantes pelos seus correspondentes valores ajustados. Assim, são feitas as análises subsequentes. Segundo Czermainski, citado por Carbonell (1995), a substituição do "outlier" pela correspondente estimativa mostrou-se satisfatória nos exemplos discutidos em sua pesquisa. 


\subsubsection{Análises de variâncias}

Foram realizadas análises individuais de variância (baseada nos dados de cada local) e análise conjunta (baseada nos dados dos três locais), para testemunhas e linhagens, utilizando-se os programas SAS mostrados nos Apêndices 4, 5 e 6.

As esperanças matemáticas dos quadrados médios foram desenvolvidas segundo a regra de Bennet \& Franklin (1963), considerando testemunhas, linhagens e locais como efeitos fixos, e conjuntos experimentais e repetições como efeitos aleatórios.

O efeito de linhagens experimentais foi considerado fixo, já que elas são originárias de diferentes cruzamentos e passaram por vários ciclos seletivos. Portanto, não representam amostras de uma mesma população. 0 efeito de locais também foi considerado fixo, apesar de pertencerem a mesma região e se localizarem próximos um do outro. Isto porque os locais são contrastantes para uma série de características, tais como: tipo de solo, nível de fertilidade, topografia, etc.

\subsubsection{Análise de variância para as testemunhas}

Com a finalidade de verificar a existência de interações entre conjuntos experimentais e as demais fontes de variação (principalmente testemunhas), inicialmente, realizaram-se análises individuais de variância, seguidas de análise conjunta para os três locais, somente com as testemunhas comuns. Efeitos significativos para tais interações indicam a necessidade de se fazer ajustes das médias das linhagens em função das médias das testemunhas, dentro de cada conjunto experimental. Caso contrário, não há necessidade de ajustes e a análise pode ser feita em blocos ao acaso. Para 
cada CM, utilizou-se os esquemas de análises de variância mostrados nas Tabelas 2 e 3.

Os modelos matemáticos empregados nestas análises foram os mesmos adotados por Farias Neto (1987), Soldini (1993), Hiromoto (1996) e Azevedo Filho (1997). Assim, a análise individual da variância para testemunhas, baseou-se no seguinte modelo:

$$
Y_{i j k}=\mu+t_{i}+r_{j}+c_{k}+(t c)_{i k}+e_{i j k}
$$

onde:

$Y_{i j k}$ : observação referente à testemunha "i" , na repetição "j", no conjunto "k";

$\mu$ : média geral do caráter;

$t_{i}$; efeito fixo da testemunha $i ; i=1, \ldots, T$;

$r_{j}$; efeito aleatório da repetição " $\mathrm{j}$ "; $r=1, \ldots, R$;

$c_{k}$; efeito aleatório do conjunto " $k$ "; $k=1, \ldots, C$;

(tc) ik: efeito aleatório da interação entre a testemunha "i" e o conjunto " $k$ ";

$e_{i j k}$ : erro experimental associado à parcela "ijk", admitido ser independente e com distribuição normal de média zero e variância $\sigma^{2}$.

A análise conjunta da variância para testemunhas, baseou-se no

modelo:

$$
\left.Y_{i j k}=\mu+t_{i}+r_{j(l)}+c_{k}+l_{1}+(t c)_{i k}+(t)\right)_{i l}+(c l)_{k l}+(t c l)_{i k l}+e_{i j k}
$$

onde:

$Y_{\mathrm{j} j \mathrm{kl}}$ : observação referente à testemunha "i", na repetição "j", no conjunto "k", no local "l"; 
$\mu$ : média geral do caráter;

$\mathrm{t}_{\mathrm{i}}$ : efeito fixo da testemunha "i"; $\mathrm{i}=1, \ldots, \mathrm{T}$;

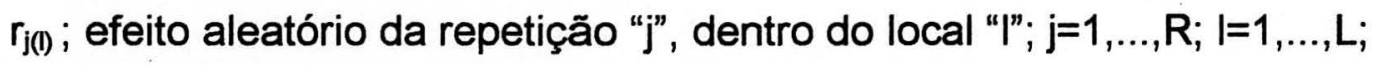

$c_{k}$ : efeito aleatório do conjunto " $k$ "; $k=1, \ldots, C$;

li: efeito fixo do local "I"; $\mid=1, \ldots, L$;

(tc) $)_{i k}$ : efeito aleatório da interação entre a testemunha "i" e o conjunto "k";

$(t \mid)_{i l:}$ efeito fixo da interação entre a testemunha " $i$ " e o local " $l$ ";

(cl) kl: efeito aleatório da interação entre o conjunto "k" e o local "l";

$(\mathrm{tcl})_{\mathrm{kk} \text { : }}$ efeito aleatório da interação tripla entre a testemunha "i", o conjunto "k" e o local "l";

$e_{\mathrm{ijk} k}$ : efeito aleatório do erro experimental médio associado à parcela "ijkl", admitido ser independente e com distribuição normal de média zero e variância $\sigma^{2}$.

\subsubsection{Análise de variância para as linhagens experimentais}

Ignorando-se o efeito de conjuntos (dado a não significância das interações com conjuntos), procedeu-se às análises da variância para as linhagens experimentais, considerando somente os efeitos de repetições e locais como fontes de variação ambiental. Empregou-se os esquemas de análises de variância das Tabelas 4 e 5 , respectivamente para as análises individuais e conjuntas dos três locais.

O modelo adotado para a análise individual de variância foi o seguinte:

$$
Y_{i j}=\mu+t_{i}+r_{j}+e_{i j}
$$

sendo: 
$Y_{i j}$ : observação do tratamento "i", na repetição "j";

$r_{j}$ : efeito de repetição "j”; $j=1, \ldots, \mathrm{J}$;

$\mu$ : média geral do caráter;

$t_{i}$ : efeito do tratamento $i ; i=1, \ldots, l$;

$e_{i j}$ : erro experimental associado à parcela "ij", admitido ser independente e com distribuição normal de média zero e variância $\sigma^{2}$.

Foi realizado o teste de homogeneidade de variâncias, obedecendo ao critério de relação máxima igual a 7 para o quociente entre o maior e menor quadrados médios do Erro (Pimentel Gomes, 1990). Em seguida, realizou-se uma análise conjunta de variância para cada $\mathrm{CM}$ reunindo os três locais, tendo como principal objetivo determinar possíveis interações de tratamentos (linhagens experimentais) com locais. $O$ modelo matemático utilizado foi:

$$
Y_{i j k}=\mu+t_{i}+r_{j(k)}+I_{k}+(t l)_{i k}+e_{i j k}
$$

onde:

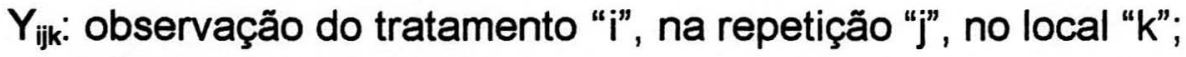

$\mu$ : média geral do caráter;

$t_{i}$ : efeito fixo do tratamento " $i$ "; $i=1, \ldots, l$;

$r_{j(k)}$ : efeito aleatório da repetição "j", dentro do local "k"; j=1, ..,J;

$l_{k}$ : efeito fixo do local " $k$ "; $k=1, \ldots, k$;

$(\mathrm{tl})_{\text {ik: }}$ : efeito fixo da interação entre o tratamento "i" e o local " $k$ " ;

$\mathrm{e}_{\mathrm{ijk}}$ : erro experimental médio associado à parcela "ijk", admitido ser independente e com distribuição normal de média zero e variância $\sigma^{2}$. 
As principais fontes de variação foram testadas com o resíduo médio, envolvendo os quadrados médios de resíduos para linhagens e testemunhas, ponderados por seus respectivos graus de liberdade, conforme a fórmula abaixo:

$$
R M P=\frac{Q M R T(G L R T)+Q M R L(G L R L)}{G L R T+G L R L}
$$

onde:

RMP: resíduo médio ponderado;

QMRT: quadrado médio do resíduo de testemunhas;

QMRL: quadrado médio do resíduo de linhagens;

GLRT: graus de liberdade do resíduo de testemunhas;

GLRL: graus de liberdade do resíduo de linhagens.

\subsubsection{Análise de médias}

Foi utilizado o teste de Tukey para comparações de médias entre as linhagens experimentais, e o Teste de Dunnett para comparação das médias de linhagens com a média das testemunhas, em cada $\mathrm{CM}$. Ambos a $5 \%$ de probabilidade. Para a realização das análises de variância e dos referidos testes utilizou-se os programas SAS apresentados nos Apêndices 6 e 7. 


\section{RESULTADOS E DISCUSSÃO}

Durante o período experimental, os desenvolvimentos vegetativo e reprodutivo das plantas ocorreram sem maiores problemas. Os fatores ambientais temperatura, umidade relativa e pluviosidade, não chegaram a trazer grandes problemas para o cultivo, nos três locais. No entanto, observouse uma baixa pluviosidade no período de granação (final de março) nos locais ESALQ e Areão, o que pode ter comprometido a produtividade potencial das linhagens, conforme observado no Apêndice 1. As semeaduras realizadas em diferentes dias, para os três locais, não deve ter levado a influências significativas do fotoperíodo sobre o NDM, já que elas ocorreram no mês de novembro, época considerada normal para o cultivo da soja no Estado de São Paulo.

Ocorreram perdas de parcelas nos seguintes experimentos: ESALQ [2 parcelas para PG, \%OL e PO (CMP e CMST)], Areão [1 parcela para PG, \%OL e PO (CMSP e CMST); 1 parcela para todos os caracteres no CMI] e Anhembi [1 parcela para PG, \%OL e PO (CMP, CMl e CMST)]. Assim, em razão do desbalanceamento gerado, as análises foram feitas sempre utilizando o procedimento GLM (modelo linear geral) do SAS.

Observa-se que, com exceção das linhagens intermediárias, nos demais ciclos de maturação (CM), os caracteres NDM, APM, Ac e VA tiveram as fontes de variação testadas com maior precisão nas análises de variância, já que para esses caracteres, não ocorreu perda de parcelas. 


\subsection{Análise de resíduos}

Os resultados mostraram a inexistência de dados discrepantes ("outliers") para NDM, APM, PG, \%OL e PO, em todos os CM. Para estes caracteres, os valores situaram-se entre os limites de dispersão -3 e +3, considerados adequados numa análise gráfica de resíduos (Parente, 1984).

Para os caracteres Ac e VA observou-se "outliers" para a maioria dos experimentos. Essa discrepância já era esperada devido às avaliações terem sido realizadas segundo uma escala de notas (1 a 5). Segundo Parente (1984), nesta situação, a transformação dos dados torna-se mais adequada do que a substituição do "outlier" por seu respectivo valor predito. A análise gráfica dos resíduos foi realizada novamente com os dados transformados para $\sqrt{x+0,5}$, não sendo detectado, desta vez, a presença de "outliers".

Por consequência, a transformação garantiu a homogeneidade de variâncias e a normalidade dos resíduos, sendo estes considerados apropriados para as análises subsequentes (Parente, 1984). Um exemplo da análise gráfica de resíduos pode ser visto na Figura 1.

\subsection{Análise de variância para as testemunhas}

Os resultados obtidos nas análises conjuntas de variâncias realizadas para as testemunhas comuns, são apresentados nas Tabelas $6,7,8$ e 9. Os efeitos de conjuntos experimentais foram não significativos pelo teste $F$ para os quadrados médios de todos os caracteres, em todos os $\mathrm{CM}$, principalmente para os efeitos de conjuntos (C) e interação conjuntos $x$ testemunhas $(\mathrm{C} \times \mathrm{T})$. Portanto, a estratificação dos tratamentos em conjuntos experimentais mostrou-se ineficiente para a maioria dos caracteres analisados, exceção feita a PG, para as testemunhas semi-precoces, que apresentaram efeitos significativos $(P<0,05)$ para essa interação. 
Esses resultados indicam a existência de efeitos pouco pronunciados de conjuntos experimentais dentro das repetições. Considerando que o efeito $C \times T$ para PG, nas testemunhas semi-precoces, foi de baixa magnitude, a exemplo de Soldini (1993), Hiromoto (1996) e Azevedo Filho (1997), optou-se por ignorar a estratificação em conjuntos, realizando-se as análises considerando somente o modelo de blocos casualizados.

A comparação das médias das testemunhas mostra que aquelas semi-precoces foram as superiores em produtividade de grãos e óleo, com médias de $2.608 \mathrm{~kg} / \mathrm{ha}$ e $531 \mathrm{~kg} / \mathrm{ha}$, respectivamente (Tabelas 18 a 21). Por sua vez, as testemunhas precoces apresentaram maior valor para \%OL, com $21,37 \%$.

\subsection{Análises de variância para as linhagens experimentais}

\subsubsection{Análises individuais}

Os valores e significâncias dos quadrados médios, médias gerais e coeficientes de variação (CV) para todos os caracteres obtidos nas análises de variância para as linhagens precoces (LP), semi-precoces (LSP), intermediárias (LI) e semi-tardias (LST), nos locais Anhembi $\left(L_{1}\right)$, Areão $\left(L_{2}\right)$ e $\operatorname{ESALQ}\left(L_{3}\right)$, são apresentados nas Tabelas 10, 11, 12 e 13.

Para as LP, LI e LST, foram detectadas diferenças significativas entre linhagens para a maioria dos caracteres, em todos os locais, com exceção para o caráter \%OL nos locais Areão (LP e LST) e Anhembi (LI), que não apresentaram diferenças significativas pelo teste $\mathrm{F}$. Isto indica a existência de pouca variabilidade neste caráter, para estes ciclos de maturação (CM). Nas LSP, foram detectadas diferenças significativas para todos os caracteres, nos três locais avaliados. 
As significâncias dos efeitos de linhagens, mostra a disponibilidade de suficiente variabilidade entre linhagens para a maioria dos caracteres nas LP, LI e LST, e para todos os caracteres nas LSP. Segundo Soldini (1993), com tais evidências, as linhagens poderão ser selecionadas por suas superioridades em desempenho médio nos vários locais de avaliação ou, por seus desempenhos superiores em relação à melhor testemunha em um ou vários locais.

Os CV's das análises individuais de variância para as linhagens exibiram menores valores para os caracteres $\operatorname{NDM}(1,18$ a $1,80 \%)$ e $\% O L(3,66$ a 9,41\%); valores intermediários para VA $(5,80$ a 11,04\%), APM $(5,26$ a15,36\%) e Ac (7,30 a $13,08 \%)$; e valores elevados para PG $(16,56$ a $30,52 \%)$ e PO $(17,23$ a 31,39). Os valores encontrados nesse estudo podem ser considerados aceitáveis, sendo concordantes com os encontrados na literatura, em experimentos dessa natureza (Soldini, 1993; Farias Neto, 1995 e Laínez-Mejía, 1996). Esses resultados indicam que a precisão experimental foi maior para NDM e \%OL; e menor para PG e PO. Magnitudes maiores de CV para PG, confirmam que o caráter, por ser quantitativo, é bastante influenciado pelo ambiente.

Observa-se que as LP e LSP sofreram menor influência dos efeitos microambientais que as LI e LST. Haja vista os menores valores de CV para os experimentos com aquelas linhagens, em relação a estas, para todos os caracteres, dentro de locais.

O maior efeito ambiental ocorreu para as LST, as quais apresentaram os maiores CV's. Alguns fatores podem ter contribuído de forma mais intensa na determinação de tais valores, principalmente, o ciclo de maturação, que sendo mais longo, expõe estes genótipos, por maior período de tempo, aos fatores ambientais não controláveis, quando comparado aos demais CM. Como exemplo, pode-se mencionar a exposição a doenças como o cancro da haste da soja (CHS), presente nos locais $L_{2}$ e $L_{3}$ (Figuras 5 e 6). Tal 
fato comprova-se quando se observa os CV's para VA, PG, \%OL e PO, que foram menores no local $L_{1}$ (ausência de CHS) e maiores nos locais $L_{2}$ e $L_{3}$ (presença de CHS).

Em termos de qualidade ambiental, o local $L_{1}$ foi mais favorável para os caracteres PG e PO, nas LP e LI; e para VA e \%OL, nas LSP. O local $\mathrm{L}_{2}$ favoreceu mais os caracteres $P G, P O, V A$ e $\% O L$, nas $L P$ e $L S P$. Já o local $\mathrm{L}_{3}$ beneficiou os caracteres PO e VA, nas LSP, PG nas $\mathrm{LI}$ e \%OL nas LP. Menores índices de $A c$ ocorreram em $L_{2}$ para as LSP. Maiores valores de NDM, APM e Ac foram observados em $L_{3}$, para todos os CM. Este resultado já era esperado, tendo em vista que $L_{3}$ apresenta textura argilosa, topografia com declive muito acentuado, associadas com bons níveis de fertilidade de solo (Apêndices $2 a$ e $2 b$ ). Estes fatores, em associação, favoreceram a ocorrência de maiores índices de Ac, neste local, quando comparado aos demais.

\subsubsection{Análises conjuntas}

Segundo Pimentel Gomes (1990), para que os experimentos conduzidos em diferentes locais possam ser reunidos em uma análise conjunta da variância, é necessário que os quadrados médios residuais sejam relativamente homogêneos. No presente estudo, embora a homogeneidade dos quadrados médios residuais, para alguns caracteres, estivesse comprometida pelo critério "F máximo" de Hartley (1950), em geral, o limite de sete vezes para o quociente entre o maior e o menor quadrados médios residuais (Pimentel Gomes, 1990) não foi superado em nenhum dos casos.

Nas Tabelas 14, 15, 16 e 17 são apresentados os quadrados médios, média geral e coeficiente de variação ( $\mathrm{CV} \%)$ correspondentes às análises conjuntas da variância, referentes aos caracteres NDM, APM, VA, Ac, $\mathrm{PG}, \% \mathrm{OL}$ e PO, para os quatro $\mathrm{CM}$. 
Observou-se que para as LP (Tabela 14), apenas o caráter Ac mostrou-se não significativo para 0 efeito da interação linhagens $x$ locais ( $G \times$ L). Nas LSP (Tabela 15), o efeito da interação $G \times L$ foi significativo $(P<0,01)$ para todos os caracteres. Para as LI (Tabela 16) esta interação apresentou significância $(P<0,01)$ para a maioria dos caracteres (NDM, APM, VA, PG e PO), exceto para Ac e \%OL. Finalmente, nas LST (Tabela 17), a grande maioria dos caracteres apresentou interação $G \times L$ significativa, com exceção agora para APM. A ausência dessa interação para \%OL, também foi reportada para os diferentes CM por Soldini (1993) e Laínez-Mejía (1996).

A significância da interação $\mathrm{G} \times \mathrm{L}$, para a maioria dos caracteres, indica a existência de um comportamento diferencial das linhagens nos ambientes avaliados e sugere a necessidade de se selecionar genótipos específicos para cada local ou identificar e selecionar aqueles que não apresentam variação através dos locais (Cruz \& Regazzi, 1994). Em relação aos diferentes $\mathrm{CM}$, os resultados mostram que, para uma determinada combinação de $\mathrm{G} \times \mathrm{L}$, um determinado $\mathrm{CM}$ pode se comportar favoravelmente em relação aos demais. O caráter PG, por exemplo, apresentou consistência para a interação $G \times L$ para todos os $C M$. Resultados similares também foram reportados por Soldini (1993), Alliprandini et al. (1994), Duarte et al. (1994) e Laínez-Mejía (1996).

A não significância da interação $\mathrm{G} \times \mathrm{L}$ para Ac (LP e LI), \%OL (LI) e APM (LST), indica que o comportamento relativo das linhagens para tais caracteres entre locais, foi semelhante. Isto possibilita a seleção de linhagens, para tais caracteres, adaptadas aos três locais. Assim, pode-se até mesmo, praticar a seleção em somente um deles e recomendar as melhores linhagens de forma generalizada, representando menores custos nos testes finais de avaliação. Esta afirmação é verdadeira, quando a análise é feita levando-se em consideração apenas esses caracteres. Ocorre que outros caracteres 
igualmente ou até mesmo mais importantes, não reagem da mesma forma, dificultando a efetivação dessa economia.

O efeito de locais foi significativo para todos os caracteres, em todos os $\mathrm{CM}$. Isto indica que os locais são variáveis para todos os caracteres, em todos os $\mathrm{CM}$. Efeito significativo para locais também foram reportados por Toledo et al. (1990) e Duarte et al. (1994) para o caráter PG, em diferentes CM. Observou-se que a magnitude da variação devido a fonte de variação locais, foi sempre maior em relação às fontes linhagens e interação $G$ $x$ L. Isto confirma as observações feitas por Romagosa \& Fox (1993) de que, a proporção da soma de quadrados devido à proporção da variância entre locais variou de 80 a $90 \%$, em relação à soma de quadrados da variação total. Os autores também identificaram que a interação $\mathrm{G} \times \mathrm{E}$ foi frequentemente maior (20\%) que o efeito principal de genótipo (10\%). Eles concluem que, como os genótipos tendem a ser mais divergentes (ao contrário das linhagens elites extremamente similares), assim como os ambientes, a interação GE tende a aumentar e alcançar facilmente 40 a $60 \%$ da variação total.

Os CV's obtidos nas análises conjuntas de variância para as linhagens experimentais mostraram, a exemplo das análises individuais, menores valores para NDM (1,44 a 1,53\%) e \%OL (4,65 a 6,65\%); valores intermediários para VA (7,38 a 8,67\%), Ac (8,08 a 10,53\%) e APM $(7,87$ a $10,71 \%)$; e maiores valores para PG $(21,53$ a $28,39 \%)$ e PO $(22,59$ a $29,03 \%)$. Isto implica em maior e menor estabilidade para NDM e PO, respectivamente. Tal estabilidade está intimamente relacionada com o tipo de herança genética apresentado por tais caracteres, sendo relativamente simples para NDM e $\% O L$, e bastante complexa para PO. Este, depende dos caracteres \%OL e PG, sendo mais influenciado por PG (Laínez-Mejía, 1996).

Observa-se que, para o caráter PG, as LP e LSP apresentaram menor influência dos efeitos macroambientais do que as LI e LST (menores valores de CV's daquelas em relação a estas, entre locais). Para NDM, \%OL e 
PO, menor influência dos efeitos macroambientais foram observados nas $\mathrm{LI}$. Para Ac e VA, uma menor influência do efeito de locais ocorreu para as LSP e LST, respectivamente.

As maiores e menores médias, para PG, foram observadas para as $\mathrm{LI}$ e LST, respectivamente. Estes resultados discordam daqueles observados por Soldini (1993) e Laínez-Mejía (1996), que detectaram as maiores médias para as LST. Segundo Soldini (1993) quanto menor a sobreposição dos desenvolvimentos das fases vegetativa e reprodutiva do ciclo biológico da planta, melhor será a distribuição da energia, canalizada na fase reprodutiva exclusivamente para o desenvolvimento de flores e grãos. Segundo Lin \& Nelson (1988), isto permite que uma grande proporção da fotossíntese, após a antese, possa estar disponível para os órgãos reprodutivos e, consequentemente, incrementar a produtividade de grãos.

De acordo com esta conclusão, dos quatro CM em estudo, as LST são as que apresentam menor sobreposição das fases vegetativa e reprodutiva, sendo portanto, teoricamente, favorecidas durante 0 desenvolvimento, para serem as mais produtivas. No entanto, fatores ambientais não controláveis podem agir, influindo negativamente na produtividade de grãos.

No presente estudo, detectou-se a incidência da doença cancro da haste da soja (CHS) para a maioria das LST, conforme pode ser observado na Tabela 21. Isto levou a baixas na produtividade de grãos nos locais $L_{2}$ e $L_{3}$ para este CM (Tabela 13). Genótipos com ciclo tardio, geralmente, ficam mais sujeitos à incidência do fungo, devido ao maior tempo de exposição no campo. Enquanto genótipos precoces, através do mecanismo de escape, conseguem ser pouco ou não reativos ao fungo, mesmo apresentando suscetibilidade genética (permanecem menos tempo no campo).

Assim, as LI que teoricamente possuiriam a segunda maior produtividade, sob o aspecto da menor sobreposição das fases vegetativa $e$ 
reprodutiva, passariam a ter a maior produtividade, já que apresentaram maior estabilidade frente aos fatores micro e macroambientais. Esta última observação foi verificada por Soldini (1993) e Laínez-Mejía (1996).

\subsection{Análise de médias}

As médias e resultados dos testes de comparações múltiplas envolvendo as linhagens (teste de Tukey) e linhagens vs testemunhas (teste de Dunnett), para todos os caracteres, dentro de cada $\mathrm{CM}$, são apresentados nas Tabelas 18, 19, 20, e 21 .

\subsubsection{Linhagens precoces}

$\mathrm{Na}$ Tabela 18 observa-se que as médias para as LP apresentaram um ciclo médio de 121 dias para o NDM; $96 \mathrm{~cm}$ para APM; 1,48 e 1,81 (média de dados transformados para $\sqrt{x+0,5}$ ) de nota para Ac e VA, respectivamente; $2.037 \mathrm{~kg} / \mathrm{ha}$ para PG; 20,72\% para \%OL; e $421 \mathrm{~kg} / \mathrm{ha}$ para PO. A comparação da média das linhagens em relação à média das testemunhas, para cada caráter, indica que as linhagens foram superiores somente para NDM e APM, mostrando-se inferiores para a maioria dos caracteres, inclusive PG. A maioria das linhagens (32 do total de 43) apresentaram de baixa a nenhuma reação ao CHS.

$O$ teste de Tukey $(P<0,05)$ revelou a existência de maiores diferenças entre linhagens para os caracteres APM, Ac, VA, PG e PO. Isto evidencia a existência de maior variabilidade para estes caracteres, quando comparado ao NDM e \%OL. Maiores divergências para PG e PO foram observadas entre as linhagens 41 (USP 94-1086) e 31 (USP 93-1008).

Baseando no número de linhagens diferindo estatisticamente da média das testemunhas, pelo teste de Dunnett $(P<0,05)$, a maior divergência 
entre linhagens e testemunhas verificou-se para os caracteres VA, APM e Ac, com 29, 13 e 12 linhagens, respectivamente. Para PG, embora algumas linhagens tenham superado, em média, às testemunhas e inclusive a melhor delas (IAC-Foscarin-31, com $2.669 \mathrm{~kg} / \mathrm{ha}$ ), como as linhagens 41 = USP 94$1086(2.871 \mathrm{~kg} / \mathrm{ha}), 39=$ USP 94-1070 $(2.744 \mathrm{~kg} / \mathrm{ha})$ e $28=$ USP 93-1203 (2.738 kg/ha), para nenhuma destas a diferença atingiu significância estatística.

\subsubsection{Linhagens semi-precoces}

$\mathrm{Na}$ Tabela 19, pode-se observar os valores médios para as LSP com ciclo médio de 128 dias para o NDM; $88,83 \mathrm{~cm}$ para APM; 1,44 para Ac; 1,87 para VA; $2.050 \mathrm{~kg} / \mathrm{ha}$ para PG; $19,59 \%$ para $\% \mathrm{OL}$; e $405 \mathrm{~kg} / \mathrm{ha}$ para PO. Médias superiores à média das testemunhas foram observadas somente para NDM e APM. A maioria das linhagens (48 do total de 63) apresentou baixa ou nenhuma reação ao $\mathrm{CHS}$.

Diferenças entre linhagens foram observadas para todos os caracteres. A maior divergência para PG e PO foi observada entre as linhagens 71 (USP 93-2316) e 80 (USP 93-2580). Maiores diferenças entre as médias de linhagens e de testemunhas foram observadas para APM, Ac, VA (33 linhagens) e NDM (30 linhagens). Para PG, alguns genótipos, em média, superaram às testemunhas $(2.608 \mathrm{~kg} / \mathrm{ha})$, tais como as linhagens $71=$ USP 93$2316(2.952 \mathrm{~kg} / \mathrm{ha}), 75=$ USP 93-2475 $(2.616 \mathrm{~kg} / \mathrm{ha}), 76=$ USP 93-2479 $(2.679 \mathrm{~kg} / \mathrm{ha}), 101$ = USP 93-2909 (2.669 kg/ha) e 105 = USP 94-1017 $(2.660 \mathrm{~kg} / \mathrm{ha})$. No entanto, essas diferenças não atingiram significância estatística e nenhuma delas conseguiram superar a melhor testemunha (FT200 , com $3.141 \mathrm{~kg} / \mathrm{ha})$. 


\subsubsection{Linhagens intermediárias}

As médias para as LI são apresentadas na Tabela 20. Observa-se um valor médio de 137 dias para NDM; $88,41 \mathrm{~cm}$ para APM; 1,49 para Ac; 1,79 para VA; $2.111 \mathrm{~kg} / \mathrm{ha}$ para PG; 18,58\% para \%OL; e $398 \mathrm{~kg} / \mathrm{ha}$ para PO. As linhagens foram superiores às testemunhas para os caracteres NDM, APM, \%OL e PO. Para PG, a média das linhagens foi aproximadamente igual à das testemunhas. A maioria das linhagens apresentou de baixa a nenhuma reação ao CHS. Porém, o número de $\mathrm{LI}$ com média a alta reação, foi superior àquele apresentado para as LP e LSP.

Diferenças significativas entre linhagens foram observadas para todos os caracteres. Para PG, as linhagens 131 (USP 93-5243) e 155 (USP 93-5980) foram as mais divergentes entre si .... Diferenças entre linhagens e testemunhas foram observadas especialmente para VA (26 linhagens) e APM (19 linhagens). Para PG e PO, somente a linhagem 131 (USP 93-5243) superou significativamente a média das testemunhas com 3.139 $\mathrm{kg} / \mathrm{ha}$ e $548 \mathrm{~kg} / \mathrm{ha}$, respectivamente. Embora não estatisticamente, outras nove linhagens (119 = USP 93-2643, 122 = USP 93-2722, 129 = USP 93-2870, 130 = 93-5082, 133 = USP 93-5423, 134 = USP 93-5539, 136 = USP 93-5549, 139 = USP 93-5582 e 143 = USP 93-5690) também superaram em PG a melhor testemunha (IAC-12, com $2.507 \mathrm{~kg} / \mathrm{ha})$.

\subsubsection{Linhagens semi-tardias}

$\mathrm{Na}$ Tabela 21, observam-se valores médios para as linhagens semi-tardias de 143 dias para NDM; 96,23 cm para APM; 1,56 para Ac; 1,68 para VA; $1.548 \mathrm{~kg} / \mathrm{ha}$ para PG; 19,06 \% para \%OL; e $297 \mathrm{~kg} / \mathrm{ha}$ para PO. A média das linhagens superou à média das testemunhas somente para os caracteres NDM e APM. A maioria dessas linhagens apresentou de média a 
alta reação ao $\mathrm{CHS}$, enquanto as testemunhas, não passaram de média reação. Isto explica, pelo menos em parte, a baixa produtividade média desses materiais (linhagens e testemunhas) em relação aos outros $\mathrm{CM}$.

Diferenças significativas foram evidenciadas para NDM, APM, VA, PG e PO. Foi observada baixa variabilidade para Ac, sendo provavelmente pequena a probabilidade de sucesso na obtenção de ganhos futuros por meio de técnicas seletivas, para tal caráter, nestas linhagens. Maior divergência para PG e PO foram observadas entre as linhagens 170 (USP 93-5513) e 184 (USP 93-5819).

No geral, poucas diferenças foram detectadas entre as linhagens e média das testemunhas, para a maioria dos caracteres. Maiores diferenças foram observadas para NDM (16 linhagens), Ac (14 linhagens) e VA (17 linhagens). Para PG, as linhagens $170=$ USP 93-5513 (2.852 kg/ha), $174=$ USP 93-5684 (2.480 kg/ha), 173 = USP 93-5672 (2.328 kg/ha) e 167 = USP 93$5391(2.277 \mathrm{~kg} / \mathrm{ha})$ foram as superiores, diferindo significativamente das testemunhas $(1.631 \mathrm{~kg} / \mathrm{ha})$. Essas linhagens também se destacaram em PO. Juntamente com as linhagens $165=$ USP 93-5263, $169=$ USP 93-5419 e $183=$ USP 93-5802, os genótipos anteriores foram ainda superiores à melhor testemunha (IAC-4, com $2.000 \mathrm{~kg} / \mathrm{ha}$ ).

\subsection{Considerações finais}

No geral, as LP apresentaram em média, maior APM e \%OL; as LSP maior VA, PO e menor índice de acamamento; as LI maior PG; e as LST maior NDM. Observa-se que as $\mathrm{LI}$, dentre todos os $\mathrm{CM}$, foi o ciclo que apresentou maior número de linhagens superando a melhor testemunha. As médias para $\mathrm{CM}$ variaram entre locais, evidenciando um comportamento diferencial dos mesmos, frente aos fatores microambientais. 
$\mathrm{O}$ teste de Tukey evidenciou maior variabilidade entre linhagens dentro de CM, para os caracteres NDM, APM, VA, PG e PO. O caráter Ac apresentou variabilidade intermediária. Tal fato indica ser grande a possibilidade de se obter ganhos futuros com a prática da seleção nesses caracteres. Por outro lado, \%OL apresentou baixa divergência entre linhagens em todos os CM, sendo observado maior intervalo de variação nas $\operatorname{LSP}(17,69$ a 22,56\%) (Tabela 19). Baixa variabilidade para \%OL entre genótipos também foi obtida por Prado (1992), Montaño-Velasco (1994), Farias Neto (1995) e Laínez-Mejía (1996). Os valores médios observados nesse caráter para as linhagens em estudo estão consistentes com os obtidos por Raut et al.(1997) e são maiores que aqueles observados por Billore \& Joshi (1997).

O intervalo de variação fenotípica média observada para os caracteres em estudo, nas linhagens avaliadas, foi a seguinte:

NDM: 116 dias (LP-8 = USP 93-1059) a 167 dias (LST-167 = USP 93-5391) APM: 55,8 cm (LSP-72 = USP 93-2320) a 138,3 cm (LSP-73 = USP 93-2329) Ac: 1,22 (algumas LP e LSP) a 1,90 (LI-137 = USP 93-5552) VA: 1,35 (LST-186 = USP 93-5847) a 2,23 (LP-7 = USP 93-1051) PG: $712 \mathrm{~kg} / \mathrm{ha}$ (LI-155 = USP 93-5980) a $3.139 \mathrm{~kg} / \mathrm{ha}$ (LI-31 = USP 93-5243) \%OL: 17,13\% (LST-178 = USP 93-5752) a 22,56\% (LSP-63 = USP 93-2171) PO: $130 \mathrm{~kg} / \mathrm{ha}$ (LI-155 = USP 93-5980) a $586 \mathrm{~kg} / \mathrm{ha}$ (LP-41 = USP 94-1086)

No geral, houve concordância entre as combinações híbridas quanto aos caracteres PG e PO, em todos os $\mathrm{CM}$. Os resultados confirmam os relatos de Farias Neto (1995) e Laínez-Mejía (1996), de que o caráter PO é mais influenciado por PG, visto que a variabilidade encontrada para \%OL é menor. Também, foi observada baixa associação entre PG e \%OL; confirmando a existência de correlação positiva, porém baixa, entre esses dois caracteres, como já foi relatado por Farias Neto (1995). 
$O$ local $L_{1}$ (Anhembi) foi favorável para $P G$ e $P O$ em todos os $C M$, exceto para as $L P$, que tiveram melhor desempenho no $L_{3}$ (ESALQ). Segundo Chaves et al. (1989), ambientes favoráveis em que a média do caráter é maior, propiciam melhor discriminação entre os genótipos. Estes locais parecem ser favoráveis para a seleção de linhagens, por evidenciarem de forma significativa a variabilidade fenotípica existente.

O local $L_{2}$ (Areão) foi desfavorável para todos os $\mathrm{CM}$. Alguns fatores possivelmente tenham contribuído para proporcionar condições desfavoráveis nesse local, como por exemplo o fator solo. Conforme se pode observar no Apêndice $2 b$, a análise química do solo revelou uma alta acidez ( $\mathrm{pH}=4,3$ ) e baixos valores para saturação de bases $(\mathrm{V}=50 \%)$, de acordo com os critérios utilizados por Malavolta et al. (1989). Outro fator que deve ter atuado mais intensamente neste local do que nos demais, foi a presença acentuada de focos erosivos em algumas parcelas, contribuindo para baixas no estande de plantas. A topografia (declive acentuado), associada com a textura do solo (areno-argilosa) são fatores que devem ter atuado favoravelmente para a ocorrência das erosões no solo. Se por um lado esse local foi desfavorável em termos de melhor expressão do potencial genético, ele discriminou melhor aquelas linhagens que sofrem menos estresses (maior estabilidade) aos fatores microambientais, como por exemplo, a alta acidez do solo.

Observou-se maior correlação entre as médias, para PG e PO, entre os locais $L_{1}$ e $L_{3}$. Segundo Soldini (1993), isto sugere que o emprego simultâneo desses dois locais pode ser útil para a seleção desses caracteres, já que suas expressões fenotípicas com maior predição do desempenho genotípico, oferecem vantagens do ponto de vista do melhoramento. Sob o ponto de vista de melhor discriminação dos genótipos, esses dois locais são considerados redundantes, pois não testam de forma adequada os genótipos, representando, neste caso, uma desvantagem para o melhoramento genético. 
O local $L_{2}$ apresentou baixa correlação entre médias com os demais locais, para tais caracteres.

Com base nas médias dos três locais, as mesmas dez linhagens superiores em PG, também o foram em PO, mas com ordens de classificação diferentes para os dois caracteres (Tabelas 22 e 23). Estas linhagens mostraram ausência ou baixa intensidade de sintomas de $\mathrm{CHS}$ e são relatadas a seguir, juntamente com suas genealogias, CM e médias para PG:

USP 93-5243.....FT 81-2.706 x PI 371610 $3.139 \mathrm{~kg} / \mathrm{ha}$ USP 93-2316.....Bossier x GO 81-11.646. LSP $.2 .952 \mathrm{~kg} / \mathrm{ha}$

USP 94-1086.....Década x FT 81-1835 LP.........2.871 kg/ha USP 93-5513.....AX 53-55-s x Paranagoiana LST. $2.852 \mathrm{~kg} / \mathrm{ha}$ USP 93-5582.....Cobb $\times$ BR-8. $2.762 \mathrm{~kg} / \mathrm{ha}$

USP 93-5539.....Paranagoiana $x$ Jackson-4028-s LI $2.752 \mathrm{~kg} / \mathrm{ha}$

USP 93-5082.....GO 81-11.646 x SOC 81-228. $2.747 \mathrm{~kg} / \mathrm{ha}$

USP 94-1070.....Primavera x FT 81-2134 $2.744 \mathrm{~kg} / \mathrm{ha}$ USP 93-1203.....Primavera $x$ SOC 81-79. LP $2.738 \mathrm{~kg} / \mathrm{ha}$ USP 93-2479.....Viçoja x GO 81-11.646. .LSP......2.679 kg/ha

Esses cruzamentos já estavam entre os selecionados como de alto potencial para produção de genótipos superiores nos trabalhos de Freire Filho (1988), Krieger (1991) e Zimback (1991). Esses resultados evidenciam que a predição dos melhores cruzamentos em gerações precoces pode antecipar aqueles que fornecerão os melhores genótipos em gerações avançadas de engodaria. Conforme observações feitas por Triller \& Toledo (1996), quando esta predição é feita no começo do programa, os materiais menos promissores podem ser descartados antes que sejam conduzidos os experimentos finais de produtividade, os quais têm custo elevado. 
$\mathrm{Na}$ Tabela 23 são apresentadas as ordens de classificação das dez melhores linhagens, dentro de seus respectivos CM. Observa-se que algumas linhagens tiveram interações específicas para determinados locais (LI135 = USP 93-5243, LI-137 = USP 93-5539, LI-142 = USP $93-5582, \mathrm{LI}-134=$ USP 93-5082 e LP-39 = USP 94-1070), enquanto outras variaram pouco entre locais (LSP-71 USP 93-2316, LP-41 = USP 94-1086, LST-170 = USP 93-5513, e LSP-76 = USP 93-2479). As primeiras poderão ser indicadas para ambientes específicos onde a interação seja positiva (boa resposta a ambientes favoráveis) e as demais, por se mostrarem mais estáveis entre locais, poderão ser recomendadas para uma ampla faixa de ambientes.

Observa-se que as linhagens superiores representam todos os $\mathrm{CM}$, com destaque para as LP e LI. Tais linhagens pertencem a ambos os programas de melhoramento, produtividade de grãos e óleo, com ligeira superioridade para este último. Isto confirma resultados anteriores de que se pode obter ganhos simultâneos com a seleção para PG e PO, já que a correlação entre ambos é positiva ( $r=0,65$ a 0,99), segundo estimativas obtidas por Zimback (1993), Soldini (1993), Montaño-Velasco (1994), Farias Neto (1995) e Laínez-Mejía (1996). Também se observa a presença de linhagens pertencendo tanto a cruzamentos adaptados (parental adaptado $\times$ parental adaptado) quanto a cruzamentos mistos (parental adaptado x parental exótico).

Sabe-se que a probabilidade de obtenção de linhagens superiores é função da frequência gênica da população, significando que melhores linhagens são mais facilmente obtidas em populações básicas formadas através da recombinação de cultivares elites. No entanto, a linhagem mais produtiva (USP 93-5243), pertence a um cruzamento misto (FT 81-2.706 x PI 371.610). Isto indica que, apesar do efeito negativo que os materiais exóticos possa exercer na média da população, resultantes de cruzamentos mistos (Vello, 1985), é possível obter genótipos superiores mesmo nestes cruzamentos, desde que o parental exótico apresente boa adaptação ao 
ambiente de cultivo. Provavelmente as referidas linhagens devem ter concentrado, com o avanço das gerações, maior número de genes para adaptação vindos do parental adaptado, em detrimento ao parental exótico.

A LI USP 93-5243 apresentou melhor combinação para os caracteres APM $(77,50 \mathrm{~cm})$, Ac $(1,40)$, VA $(1,97)$ e PG $(3.139 \mathrm{~kg} / \mathrm{ha})$. Entretanto, a LP USP 94-1070 apresentou boa combinação para precocidade (121 dias), PG (2.744kg/ha), \%OL (21,12\%), PO (579 kg/ha) e reação ao CHS (NR). Existe grande probabilidade de que esta linhagem apresente resistência ao CHS, pois segundo Siviero et al. (1997), um de seus parentais (Primavera) apresenta genes de resistência para a doença. Alguns parentais (Forrest, Foster e SOC 81-79) presentes em alguns cruzamentos (Tabela 1) são resistentes ao nematóide do cisto da soja (Hiromoto, 1996) e podem ter transmitido os genes de resistência a suas progênies.

No presente estudo, duas $\mathrm{LI}$ foram obtidas de cruzamentos envolvendo o parental Paranagoiana, portador de genes que condicionam período juvenil longo. Assim, é grande a probabilidade dessas linhagens apresentarem tal característica. Dessa forma, elas poderão ser indicadas para cultivo fora da época normal de semeadura e ou para cultivo em baixas latitudes.

As causas que possivelmente tenham mais contribuído em maior grau para a interação $\mathrm{G} \times \mathrm{L}$, foram aquelas relacionadas ao fatores ambientais previsíveis, como características físicas e químicas do solo, práticas culturais e a presença acentuada de doenças. Assim, os resultados obtidos neste estudo, estão mais consistentes com aqueles encontrados por Kang et al. (1989), os quais concluíram em seu estudo, que os ciclos de maturidade foram mais afetados por fertilidade diferencial de solos e/ou práticas culturais do que fatores do tempo.

O estudo da interação $G \times L$ foi útil para informar sobre a previsibilidade espacial do grupo de linhagens, ou seja, suas reações às 
variações previsíveis do ambiente, para os diferentes $\mathrm{CM}$. No entanto, mais avaliações serão necessárias para verificar o comportamento dessas linhagens em diferentes anos, principalmente as linhagens provenientes de cruzamentos envolvendo parentais exóticos. Assim, pode-se ter melhor conhecimento dos efeitos das variações imprevisíveis do ambiente sobre esses genótipos. Gieco (1997) comenta que a seleção de progênies com base nas médias de três anos de avaliação, possibilita a retenção das mais produtivas, e que a aplicação de altas intensidades de seleção, em um determinado ano, pode representar a perda de muitas progênies promissoras. Logo, sob tais circunstâncias, é recomendável a aplicação de baixas intensidades de seleção inicialmente, para gradativamente identificar as progênies superiores. 


\section{CONCLUSÕES}

Os resultados obtidos neste estudo permitem as seguintes conclusões:

a) Existe variabilidade genética entre linhagens para os diferentes ciclos de maturação e caracteres, com exceção da porcentagem de óleo (\%OL);

b) Em termos de qualidade ambiental favorável para as linhagens expressarem os seus potenciais genéticos, destacou-se o local Anhembi seguido pelo local ESALQ, ambos mais favoráveis que o local Areão;

c) A interação genótipos $x$ locais $(G \times L)$ mostrou-se um importante componente da variação fenotípica para os diferentes ciclos de maturação e caracteres, com exceção de acamamento (linhagens precoces e intermediárias) e da $\% O L$ (linhagens intermediárias);

d) A forte associação observada entre produtividade de grãos (PG) e produtividade de óleo (PO) permitiu a seleção de linhagens superiores nos dois programas de melhoramento (alta PG e alta PO); todavia a \%OL provocou diferenças nas ordens de classificação das linhagens para PG e $\mathrm{PO}$; 
e) PG e PO variaram com o ciclo de maturação e com os locais de cultivo; para os três locais em conjunto, ocorreu a seguinte ordem decrescente de classificação: intermediárias, semi-precoces, precoces e semi-tardias;

f) As ordens de classificação das linhagens dentro dos ciclos de maturação variaram entre os locais para PG e PO; as linhagens que mais se destacaram foram USP 93-5243 (intermediária), USP 93-2316 (semiprecoce), USP 94-1086 (precoce) e USP 93-5513 (semi-tardia), para a combinação dos três locais;

g) A intensidade dos sintomas de cancro da haste da soja (CHS) foi crescente com o aumento do ciclo de maturação das linhagens, nos dois locais onde ocorreu infecção natural. 


\section{REFERÊNCIAS BIBLIOGRÁFICAS}

AGRIANUAL. FNP Consultoria \& Comércio, p. 377-378, 1998.

AKHTER, M.; SNELLER, C. H. Genotype $x$ planting date interaction and selection of early maturing soybean genotypes. Crop Science, v.36, p. 883889, 1996.

ALLARD, R. W. Princípios do melhoramento genético das plantas. Rio de Janeiro: USAID/Edgard Blucher, 1971. 381p.

ALLARD, R. W.; BRADSHAW, A. D. Implications of genotype-environmental interactions in applied plant breeding. Crop Science, v.4, p. 503-508, 1964.

ALLIPRANDINI, L. F. Estudo dos efeitos ambientais, estabilidade, adaptabilidade e ganho genético em linhagens de soja (Glycine max (L.) Merrill) no Estado do Paraná. Londrina, 1992. 122p. Dissertação (Mestrado) - Universidade Estadual de Londrina.

ALLIPRANDINI, L. F.; TOLEDO, J. F. F. de.; FONSECA JUNIOR, N. F.; ALMEIDA, L. A. de.; KIIHL, R. A. S. Efeitos da interação genótipo $x$ ambiente sobre a produtividade da soja no Estado do Paraná. Pesquisa Agropecuária Brasileira, v. 29, n. 9, p.1433-1444, set. 1994.

ALLIPRANDINI, L. F.; TOLEDO, J. F. F. de.; FONSECA JUNIOR, N. S.; KIIHL, R. A. S. Ganho genético em soja no Estado do Paraná, via melhoramento no período de 1985/86 a 1989/90. Pesquisa Agropecuária Brasileira, v. 28, n. 4, p. 473-479, 1993. 
ALMEIDA, L. A. de.; KIIHL, R. A. Melhoramento da soja no Brasil - desafios e perspectivas. In: CÂMARA, G. M. S. Soja: tecnologia da produção. Piracicaba: Publique, 1998. p. 40-54.

ARANTES, N. E. Interação genótipo $x$ ambiente e estudo de alternativas para seleção de variedades de soja (Glycine max (L.) Merrill), com base em testes regionais. Viçosa, 1979. 51p. Dissertação (M.S) - Universidade Federal de Viçosa.

AZEVEDO FILHO, J. A. de. Potencialidade de linhagens experimentais de soja em solos contrastantes na saturação de alumínio. Piracicaba, 1997. 138p. Tese (Doutorado) - Escola Superior de Agricultura "Luiz de Queiroz", Universidade de São Paulo.

BASFORD, K. E.; COOPER, M. Genotype x environment interactions and some considerations of their implications for wheat breeding in Australia. Australian Journal Agricultural Research, v. 49, p. 153-174, 1998.

BATITUCCI, G. Adaptabilidade e estabilidade de genótipos de soja (Glycine $\max ($ L.) Merrill) quanto à produção de grãos e à altura de planta, em Minas Gerais. Viçosa, 1990. 84p. Dissertação (M.S.) - Universidade Federal de Viçosa.

BECKER, H. C.; LÉON, J. Stability analysis in plant breeding. Plant Breeding, v. 101, p. 1-23, 1988.

BENNETT, C. A.; FRANKLIN, N. L. Statistical analysis in chemistry and the chemical industry. New York: John Wiley and Sons, 1963. 724p.

BHERING, M. C. Influência de épocas de plantio sobre algumas características agronômicas e qualidades das sementes de soja (Glycine max (L.) Merrill). Viçosa, 1989. 57p. Dissertação (M.S) - Universidade Federal de Viçosa.

BILLORE, S. D.; JOSHI, O. P. Genotypical variability for yield and quality in Glycine max (L.) Merrill. Soybean Genetics Newsletter, v. 24, p. 88-91, 1997. 
BONATO, E. R. Estabilidade fenotípica da produção de grãos de dez cultivares de soja (Glycine max (L.) Merrill) nas condições do Rio Grande do Sul. Piracicaba, 1978. 75p. Dissertação (Mestrado) - Escola Superior de Agricultura "Luiz de Queiroz", Universidade de São Paulo.

BRASIL, E. M. Comparação de métodos de controle da interação genótipo $x$ ambiente em milho (Zea mays L.). Goiânia, 1990. 214p. Dissertação (Mestrado) - Universidade Federal de Goiânia.

BURTON, J. W. Soyabean (Glycine $\max$ (L.) Merrill). Field Crops Research, v.53, p.171-186, 1997.

CÂMARA, G. M. de. Ecofisiologia da soja e rendimento. In: CÂMARA, G. M. S. Soja: tecnologia da produção. Piracicaba: Publique, 1998. p. 256-277.

CARBONELL, S. A. M. Análise genética da reação da semente de soja ao dano mecânico avaliada em um dialelo do ciclo precoce. Piracicaba, 1995. 144p. Tese (Doutorado) - Escola Superior de Agricultura "Luiz de Queiroz", Universidade de São Paulo.

CHAVES, L. J.; VENCOVSKY, R.; GERALDI, I. O. Modelo não linear aplicado ao estudo da interação genótipo $x$ ambiente em milho. Pesquisa Agropecuária Brasileira, v. 24, n. 2, p. 259-269, fev. 1989.

COBER, E. R.; FRÉGEAU-REID, J. A.; PIETRZAK, L. N.; MCELROY, A. R.; VOLDENG, H. D. Genotype and Environmental effects on natto soybean quality traits. Crop Science, v. 37, p. 1151-1154, 1997.

COCKERHAM, C. C. Estimation of genetics variance. In: HANSON, W. D.; ROBINSON, H. F. Statistical genetics and plant breeding. Madison: National Academy os Sciences, 1963. p. 53-94.

COMSTOCK, R. E. Quantitative genetics with special reference to plant and animal breeding. Ames: Iwoa State University Press, 1996. 421p.

COMSTOCK, R. E.; MOLL, R. H. Genotype-environment interactions. In: HANSON, H.D.; ROBINSON, H.F.(Ed.) Statistical genetics in plant breeding. Washington: National Academy of Sciences National Research Council, 1963. p.164-196. 
COSTA, J. A. Cultura da soja. Porto Alegre: Evangraf, 1996. 233p.

CRUZ, C. D.; CASTOLDI, F. L. Decomposição da interação genótipos $x$ ambientes em partes simples e complexa. Revista Ceres, v.38, n. 219, p. 422-430, 1991.

CRUZ, C. D.; REGAZZI, A. J. Modelos biométricos aplicados ao melhoramento. Viçosa: Imprensa Universitária da UFV, 1994. 390p.

CRUZ, C. D.; TORRES, R. A. A.; VENCOVSKY, R. An alternative to the stability analysis proposed by Silva and Barreto. Revista Brasileira de Genética, v. 12, p. 567-580, 1989.

DUARTE, J. B.; ROLIM, R. B.; OLIVEIRA, P. M. F. de.; SOUZA, J. R. de. Adaptabilidade e estabilidade de rendimento de genótipos de soja (Glycine $\max$ (L.) Merrill), nas condições de Goiás e Distrito Federal. Anais da Escola de Agronomia e Veterinária, v. 24, n.1, p. 90-109, 1994.

DUDLEY, J. W. Molecular marker in plant improvement: manipulation of genes affecting quantitative traits. Crop Science, v.33, p. 660-668, 1993.

DUTRA, J. H. Comportamento de quinze genótipos de soja (Glycine max (L.) Merrill) em diferentes épocas de plantio, em Capinópolis, Minas Gerais. Viçosa, 1986. 59p. Dissertação (M.S.) - Universidade Federal de Viçosa.

EBERHART, S. A.; RUSSEL, W. A. Stability parameters for comparing varieties. Crop Science, v. 6, p. 36-40, 1966.

FALCONER, D. S. Introduction to quantitative genetics. 3 ed. Harlow. Longman, 1989. 438p.

FALCONER, D. S.; MACKAY, T. F. C. Introduction to quantitative genetics. 4 ed. Harlow. Longman, 1996. 464p.

FARIAS NETO, J. T. de. Comportamento e variabilidade de genótipos de soja (Glycine max (L.) Merrill) em cultivos de verão e inverno. Piracicaba, 1987. 87p. Dissertação (Mestrado) - Escola Superior de Agricultura "Luiz de Queiroz", Universidade de São Paulo. 
FARIAS NETO, J. T. Potencialidade de progênies $F_{4: 3}$ e $F_{5: 3}$ derivadas de cruzamentos em cadeia para produtividade de óleo em soja. Piracicaba, 1995. 150p. Tese (Doutorado) - Escola Superior de Agricultura "Luiz de Queiroz", Universidade de São Paulo.

FEHR, W. R. Principles of cultivar development. New York: Macmillan, 1987. cap. 18, p. 247-258.

FEHR, W. R.; CAVINESS, C. C. Stages of soybean development. Ames: lowa State University, 1977. 12p. (Special Report,80).

FINLAY, K. W.; WILKINSON, G. N. The analysis of adaptation in a plantbreeding programme. Australian Jounal Agricultural Research, v. 14, p. $742-754,1963$.

FREIRE FILHO, F. R. Análise genética de um dialelo entre genótipos precoces de soja (Glycine max (L.) Merrill). Piracicaba, 1988. 224p. Tese (Doutorado) - Escola Superior de Agricultura "Luiz de Queiroz", Universidade de São Paulo.

GALVÃO, E. R. Adaptabilidade e estabilidade de comportamento de nove genótipos de soja (Glycine max (L.) Merrill) em Ponta Porã, Mato Grosso do Sul. Viçosa, 1994. 52p. Dissertação (M.S.) - Universidade Federal de Viçosa.

GAUCH JUNIOR, H. G.; ZOBEL, R. W. AMMI analysis of yield trials. In: KANG, M. S.; GAUCH JUNIOR, H. G. Genotype-by-environment interaction. Boca Raton: CRC Press, 1996. cap.1, p1-14.

GIECO, J. O. Interação genótipos $x$ ambientes e implicações para o melhoramento da soja. Piracicaba, 1997. 98p. Dissertação (Mestrado) Escola Superior de Agricultura "Luiz de Queiroz", Universidade de São Paulo.

GOMES, R. L. F. Análise genética de progênies $F_{6}$ e $F_{7: 6}$ de soja obtidas de cruzamentos dialélicos. Piracicaba, 1995. 140p. Tese (Doutorado) - Escola Superior de Agricultura "Luiz de Queiroz", Universidade de São Paulo.

HANSON, W. D. Distance statistics and interpretation of Southern states regional soybean tests. Crop Science, v.34, p.1498-1504, 1994. 
HIROMOTO, D. M. Seleção de genótipos de soja para performance agronômica e resistência a Heterodera glycines Ichinohe e Diaporthe phaseolorum f.sp. meridionalis Morgan - Jones. Piracicaba, 1996. 84p. Tese (Doutorado) Escola Superior de Agricultura "Luiz de Queiroz", Universidade de São Paulo.

HARTLEY, H. O. The use of range in analysis of variance. Biometrika, v. $37, p$. 271-280, 1950.

HYMOWITZ, T.; SINGH, R. J.; KOLLIPARA, K. P. Biosystematics of the genus Glycine, 1996. Soybean Genetics Newsletter, v.24, p. 119-120, May 1997.

HUHN, M. Nonparametric analysis of genotype $x$ environment interactions by ranks. In: KANG, M. S.; GAUCH JUNIOR, H. G. Genotype-by-environment interaction. Boca Raton: CRC Press, 1996. cap.9, p. 235-270.

JINKS, J. L.; POONI, H. S. The genetic basis of environmental sensitivity. In: INTERNATIONAL CONFERENCE ON QUANTITATIVE GENETICS, 2 ., Raleigh, 1987. Proceedings. Sunderland: Sinauer Associates, 1988. p. 505-526.

JOHNSON, H. W.; ROBINSON, H. F.; COMSTOCK, R. E. Estimates of genetic and environmental variability in soybeans. Agronomy Journal, v.47, n. 7, p. 314-318, 1955.

KANG, M. S.; HARVILLE, B. G.; GORMAN, D. P. Contribution of weather variables to genotype $x$ environment interaction in soybean. Field Crops Research, v. 21, p. 297-300, 1989.

KANG, M. S.; MAGARI, R. New developments in selecting for phenotypic stability in crop breeding. In: KANG, M. S.; GAUCH JUNIOR, H. G. Genotype-by-environment interaction. Boca Raton: CRC Press, 1996. cap.1, p. 1-14.

KRIEGER, M. Análise dialélica envolvendo dez parentais semi-precoces de soja (Glycine max (L.) Merrill). Piracicaba, 1992. 65p. Dissertação (Mestrado) - Escola Superior de Agricultura "Luiz de Queiroz", Universidade de São Paulo. 
LAÍNEZ-MEJÍA, J. R. Implicações da interação genótipos $x$ ambientes na seleção de progênies de soja com ênfase nas produtividades de grãos e óleo. Piracicaba, 1996. 145p. Tese (Doutorado) - Escola Superior de Agricultura "Luiz de Queiroz", Universidade de São Paulo.

LIN, S. M.; NELSON, R. L. Effect of plant height and flowering date on seed yield of determinate soybean. Crop Science, v.28, p. 218-222, 1988.

MALAVOLTA, E.; VITTI, G. C.; OLIVEIRA, S. A. de. Avaliação do estado nutricional das plantas: princípios e aplicações. Piracicaba: Potafos, 1989. 201p.

MARIOTTI, J. A .; OYARZABAL, E. S.; OSA, J. M.; BULACIO, A . N. R.; ALMADA, G. H. Analisis de stabilidad y adaptabilidad de genotipos de cana de azucar. I. Interacciones dentro de una localidad experimental. Revista Agronomica Nacional Argentina, v. 13, p. 105-127, 1976.

MONELLI, V. L. Distância de cultivares em relação ao melhor genótipo na análise de grupos de experimentos. Piracicaba, 1996. 178p. Dissertação (Mestrado) - Escola Superior de Agricultura "Luiz de Queiroz", Universidade de São Paulo.

MONTAÑO-VELASCO, J. C. Análise genética de progênies $F_{3}$ de soja derivadas de cruzamentos em cadeia com ênfase na produtividade de óleo. Piracicaba, 1994. 115p. Tese (Doutorado) - Escola Superior de Agricultura "Luiz de Queiroz", Universidade de São Paulo.

MORAES, L. K. de.; PINHEIRO, J. B.; COELHO, S. G.; ROSA, S. R.A. da.; REIS, A. J. S. Interação de cultivares de soja com épocas de semeadura. In: CONGRESSO NACIONAL DE GENÉTICA, 43.,Goiânia, 1997. Anais. Goiânia: SBG, 1997. p. 166.

MOREIRA, R. M. P. Predição do comportamento de cruzamentos dialélicos de soja avaliados na geração $F_{3}$ em cultivo de inverno. Piracicaba, 1992. 95p. Dissertação (Mestrado) - Escola Superior de Agricultura "Luiz de Queiroz", Universidade de São Paulo.

NASS, L. L. Potencialidade de genótipos de soja (G/ycine max (L.) Merrill) para cultivo de inverno avaliada por cruzamentos dialélicos. Piracicaba, 1989. 112p. Dissertação (Mestrado) - Escola Superior de Agricultura "Luiz de Queiroz", Universidade de São Paulo. 
OLIVEIRA, I. O. de . Estabilidade fenotípica de cultivares de soja (Glycine max (L.) Merrill) em relação a elementos climáticos. Viçosa, 1990. 56p. Dissertação (M.S.) - Universidade Federal de Viçosa.

PARENTE, R. C. P. Aspectos da análise de resíduos. Piracicaba, 1984. 139p. Dissertação (Mestrado) - Escola Superior de Agricultura "Luiz de Queiroz", Universidade de São Paulo.

PFEIFFER, T. W.; GRABAU, L. J.; ORF, J. H. Early maturity soybean production system: genotype $x$ environment interaction between regions of adaptation. Crop Science, v.35, p. 108-112, 1995.

PIMENTEL GOMES, F. Curso de estatística experimental. 13 ed. Piracicaba: Nobel, 1990. 468p.

PRADO, L. C. Perspectivas para o melhoramento de linhagens homozigóticas de soja, com ênfase em produção de grãos e teor de proteína. Piracicaba, 1994. 128p. Dissertação (Mestrado) - Escola Superior de Agricultura "Luiz de Queiroz", Universidade de São Paulo.

RAMALHO, M. A. P.; SANTOS, J. B. dos.; ZIMMERMANN, M. J. O. de. Genética quantitativa em plantas autógamas: aplicações ao melhoramento do feijoeiro. Goiânia: UFG, 1993. cap. 6, p. 138-170.

RAUT, V. M.; TAWARE, S. P.; HALVANKAR, G. B.; PATIL, V. P. Stability analysis for oil and yield in soybean. Soybean Genetics Newsletter, v. 24, p. 92-93, 1997.

ROMAGOSA, I.; FOX, P. N. Genotype $x$ environment interactions and adaptation. In: HAYWARD, M. D.; BOSEMARK, N. O.; ROMAGOSA, I. Plant breeding: principles and prospects. London: Chapman \& Hall, 1993, chapter 20, p. 375-390.

SAS, Institute Inc. SAS User's Guide: Statistic, version 6.11 Edition. Cary, NC: SAS Institute Inc, 1996. 956p.

SCOTT, R. A.; CHAMPOUX, M.; SCHAPAUGH JUNIOR, W. T. Influence of environmental productivity level and yield stability on selection strategies in soybean. Euphytica, v. 78, p. 115-122, 1994. 
SHIMOYA, A. Comportamento de genótipos de soja (Glycine max (L.) Merrill) nas gerações $F_{9}$ e $F_{10}$ selecionadas pelo método do teste de seleção precoce. Viçosa, 1987. 132p. Dissertação (M.S.) - Universidade Federal de Viçosa.

SILVA, J. G. C.; BARRETO, J. N. Aplicação de regressão linear segmentada em estudos da interação genótipo $x$ ambiente. In: SIMPÓSIO DE ESTATÍSTICA APLICADA À EXPERIMENTAÇĀO AGRONÔMICA, 1., Campinas, 1985. Resumos, Campinas, 1985. p. 49-50.

SIVIERO, A.; MENTEN, J. O; VELLO, N.A. Herança da resistência da soja a Diaphorte phaseolorum f. sp. Meridionalis. Summa Phytopathologica, v. 23, n.2, p. 139-142, 1997.

SNELLER, C. H.; KILGORE-NORQUEST, L.; DOMBEK, D. Repeatability of yield stability statistics in soybean. Crop Science, v.37, p. 383-390, 1997.

SOLDINI, D. 0 . Interação genótipos $x$ locais e correlações entre caracteres com ênfase na produtividade de óleo em soja. Piracicaba, 1993. 136p. Dissertação (Mestrado) - Escola Superior de Agricultura "Luiz de Queiroz", Universidade de São Paulo.

TAKEDA, C. Avaliação de progênies de feijoeiro do cruzamento "ESAl-501 x "A 354" em diferentes ambientes. Lavras, 1990. 82p. Dissertação (M.S.) Escola Superior de Agricultura de Lavras.

TOLEDO, J. F. F.; ALMEIDA, L. A.; HILL, R. F. S.; MENOSSO, O . G. Ganho genético em soja no Estado do Paraná, via melhoramento. Pesquisa Agropecuária Brasileira, v. 25, p. 89-94, 1990.

TOLER, J. E. Patterns of genotypic performance over environmental arrays. Clemson, 1990. 154p. Thesis (Ph.D.) - Graduate School of Clemson University.

TOMKINS, J. P.; SHIPE, E. R. Environmental adaptation of long-juvenile soybean cultivars and elite strains. Agronomy Journal, v. 89, p. 257-262, 1997.

TRILLER, C.; TOLEDO, F. F. de. Using the $F_{3}$ generation for predicting potential of soybean crosses. Revista Brasileira de Genética, v.19, n.2, p. 289-294, 1996. 
UPHOFF, M. D.; FEHR, W. R.; CIANZIO, S. R. Genetic gain for soybean seed yield by three recurrent selection methods. Crop Science, v. 37, p. 1155$1158,1997$.

VAN RAAMSDONK, L. W. D. The cytological and genetical mechanisms of plant domestication exemplified by four crop models. Botanic Review, $\mathrm{v}$. 61, p. 367-399, 1995.

VELLO, N. A. Base genética, fontes de genes e métodos de melhoramento para resistência a doenças. In: ENCONTRO SOBRE TEMAS DE GENÉTICA E MELHORAMENTO, 12., Piracicaba, 1995. Anais. Piracicaba: Departamento de Genética - ESALQ/USP, 1995. p. 11-23.

VELLO, N. A. Ampliação da base genética do germoplasma e melhoramento de soja na ESALQ/USP. In: SIMPÓSIO SOBRE A CULTURA E PRODUTIVIDADE DA SOJA, 1., Piracicaba, 1991. Anais. Piracicaba: FEALQ, 1992. p. 60-81.

VELLO, N. A. Efeitos da introdução de germoplasma exótico sobre a produtividade e relações com a base genética dos cultivares de soja (Glycine max (L.) Merrill). Piracicaba, 1985. 91p. Tese (Livre-Docência) Escola Superior de Agricultura "Luiz de Queiroz", Universidade de São Paulo.

VELLO, N. A. Influência do ambiente na manifestação dos genes. Piracicaba: Departamento de genética - ESALQ/USP, 1986. 24p.

VELLO, N. A.; HIROMOTO, D. M.; AZEVEDO FILHO, A. J. B. V. Coefficient of parentage and breeding of Brazilian soybean germplasm. Revista Brasileira de Genética, v.11, n.3, p.679-697, set.1988.

VENCOVSKY, R.; BARRIGA, P. Genética biométrica no fitomelhoramento. Ribeirão Preto: Revista Brasileira de Genética, 1992. 486p.

VENCOVSKY, R.; TORRES, R. A. A. Estabilidade geográfica e temporal de algumas cultivares de milho. In: CONGRESSO NACIONAL DE MILHO E SORGO, 16., Belo Horizonte, 1988. Anais. Belo Horizonte: EMBRAPACNPMS, 1988. p. 294-300. 
VERMA, M. M.; CHAHAL, G. S.; MURTY, B. R. Limitations of conventional regression analysis: a proposed modification. Theoretical and Applied Genetics, v. 53, p. 89-91, 1978.

XU, B.; ZHEN, H.; LU, Q.; ZHAO, S. HU, Z. Three evidence of the original area of soybean. In: WORLD SOYBEAN RESEARCH CONFERENCE. Proceedings. 4., Buenos Aires, 1988. Buenos Aires: Asssociation Argentina de la Soja, 1989. p. 124-128.

YORINORI, J. T. Controle integrado das principais doenças da soja. In: CÂMARA, G. M. S. Soja: tecnologia da produção. Piracicaba: Publique, 1998. p. 139-192.

ZIMBACK, L. Cruzamento em cadeia entre genótipos adaptados e exóticos de soja com ênfase na produção de óleo. Piracicaba, 1993. 163p. Tese (Doutorado) - Escola Superior de Agricultura "Luiz de Queiroz", Universidade de São Paulo. 
FIGURAS 


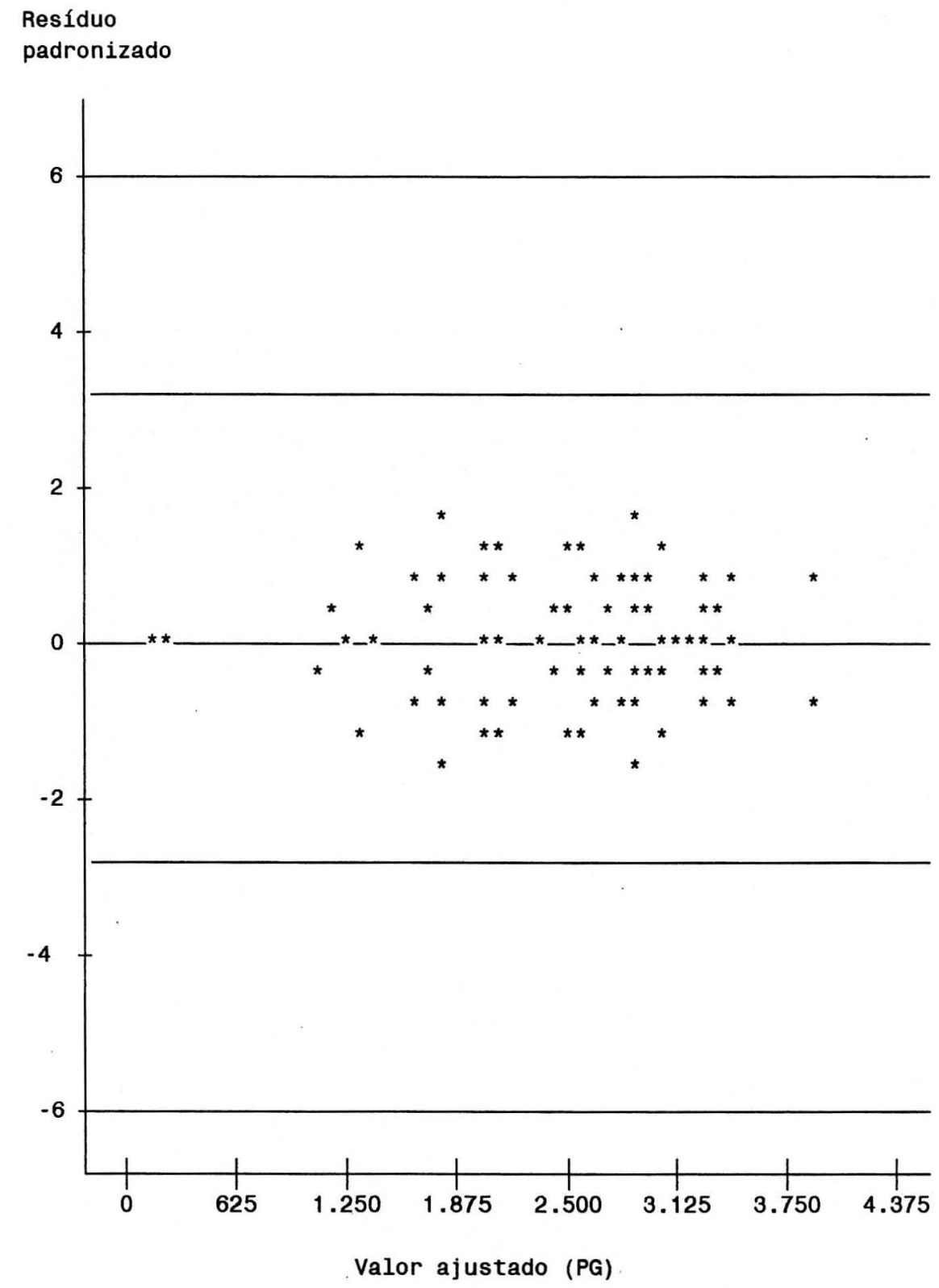

OBS: 31 observações sobrepostas.

Figura 1. Representação gráfica dos resíduos padronizados e valores ajustados para o caráter produtividade de grãos (PG), experimento precoce, local ESALQ. Soja, Piracicaba, SP (semeadura em 06/11/96). 


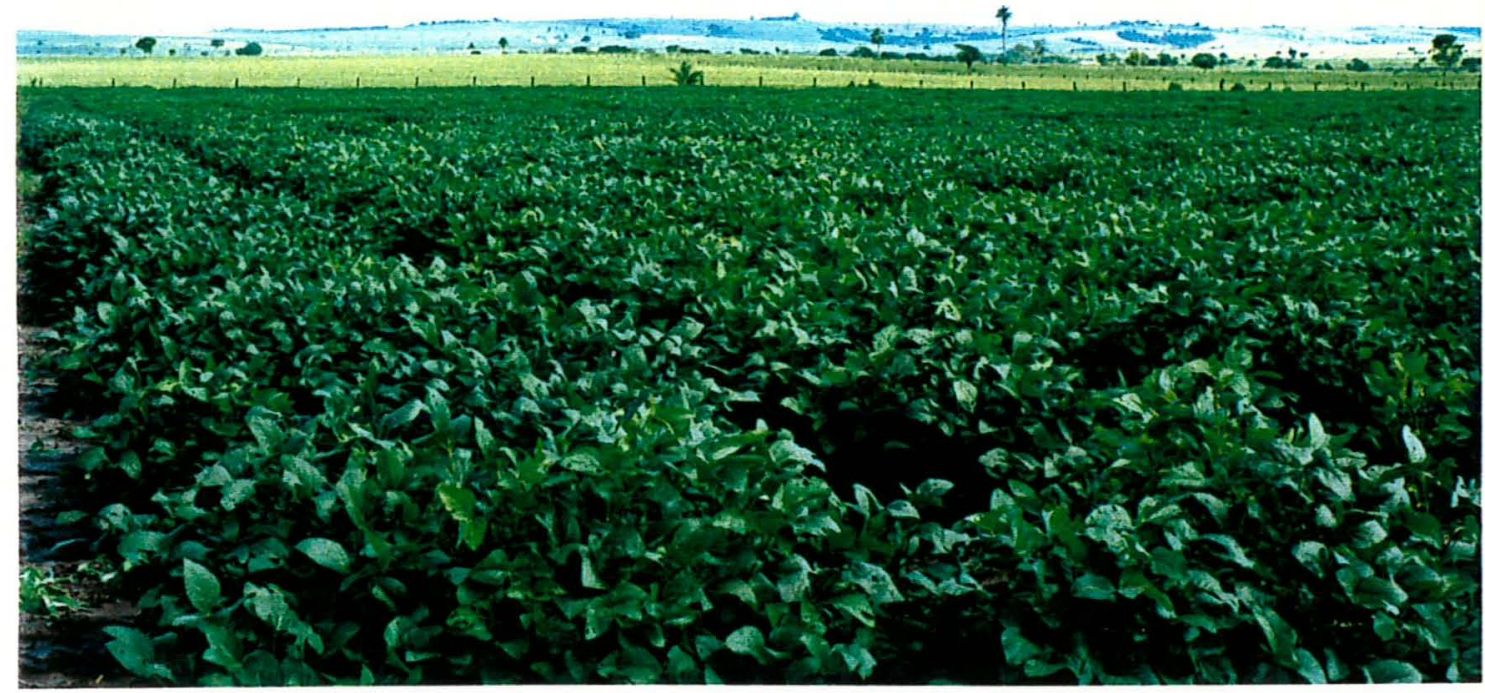

Figura 2. Vista panorâmica dos experimentos conduzidos no local Anhembi. Soja, Piracicaba, SP (semeadura em 20/11/96).

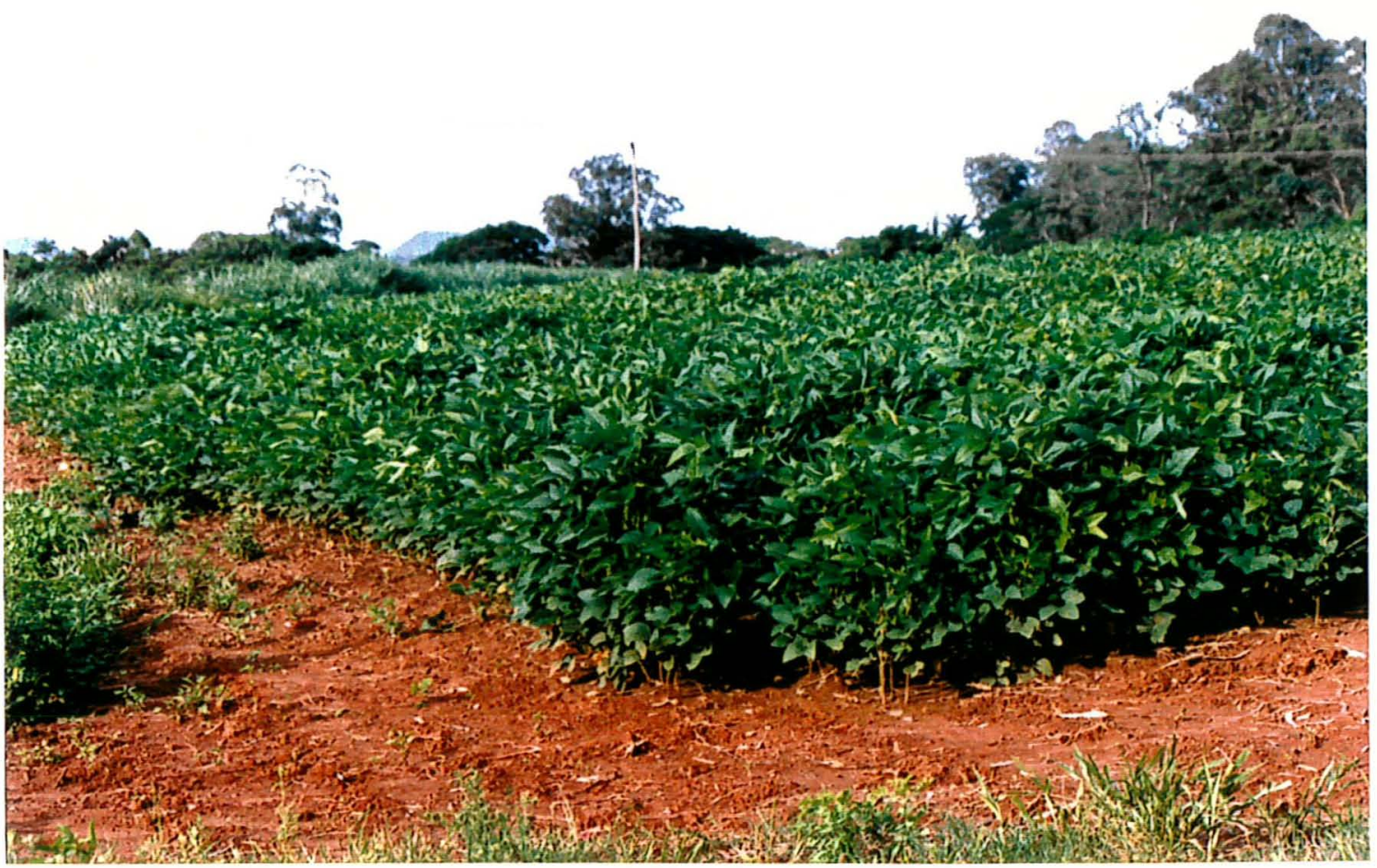

Figura 3. Vista panorâmica dos experimentos conduzidos no local Areão. Soja, Piracicaba, SP (semeadura em 12/11/96). 


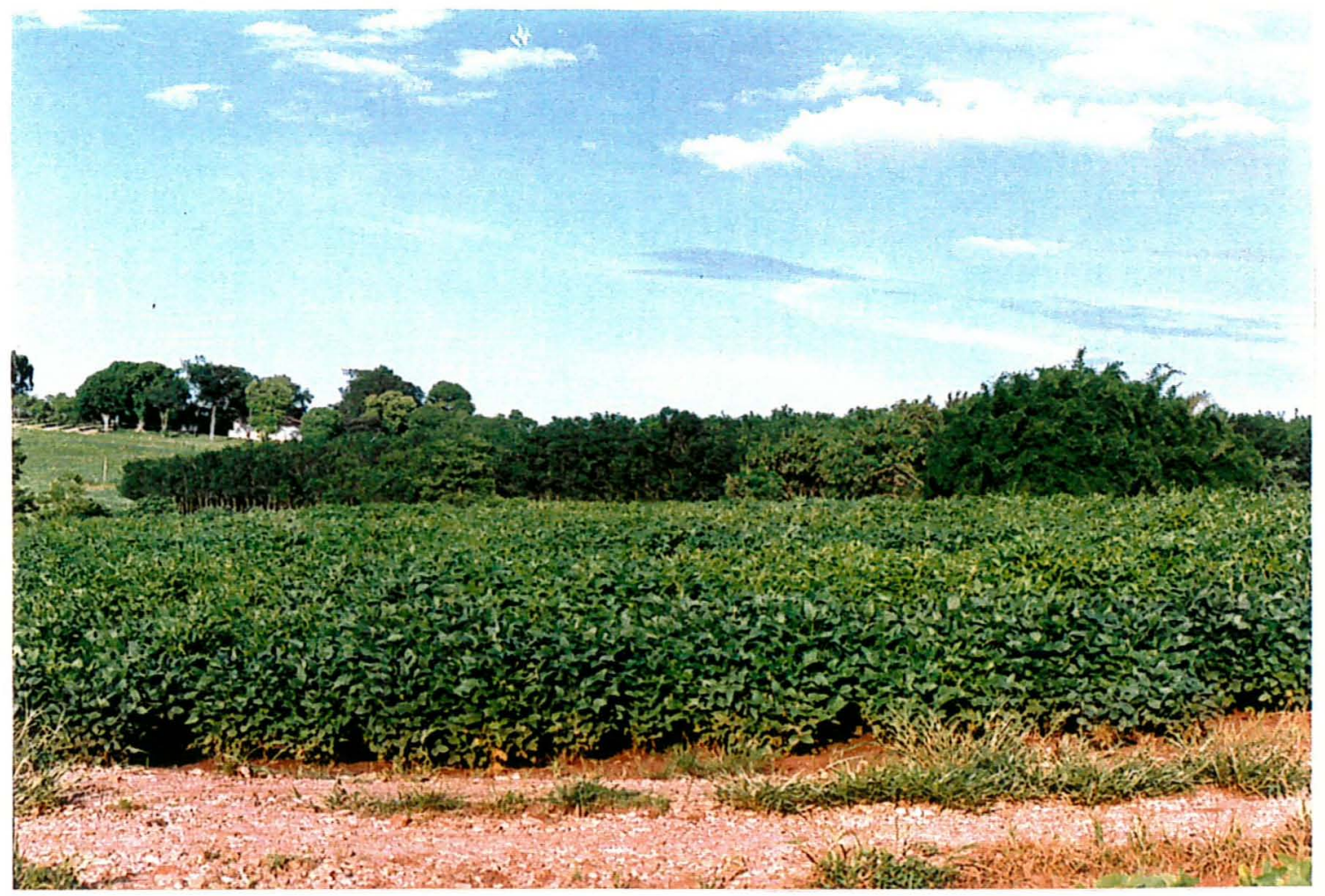

Figura 4. Vista panorâmica dos experimentos conduzidos no local ESALQ. Soja, Piracicaba, SP (semeadura em 06/11/96).

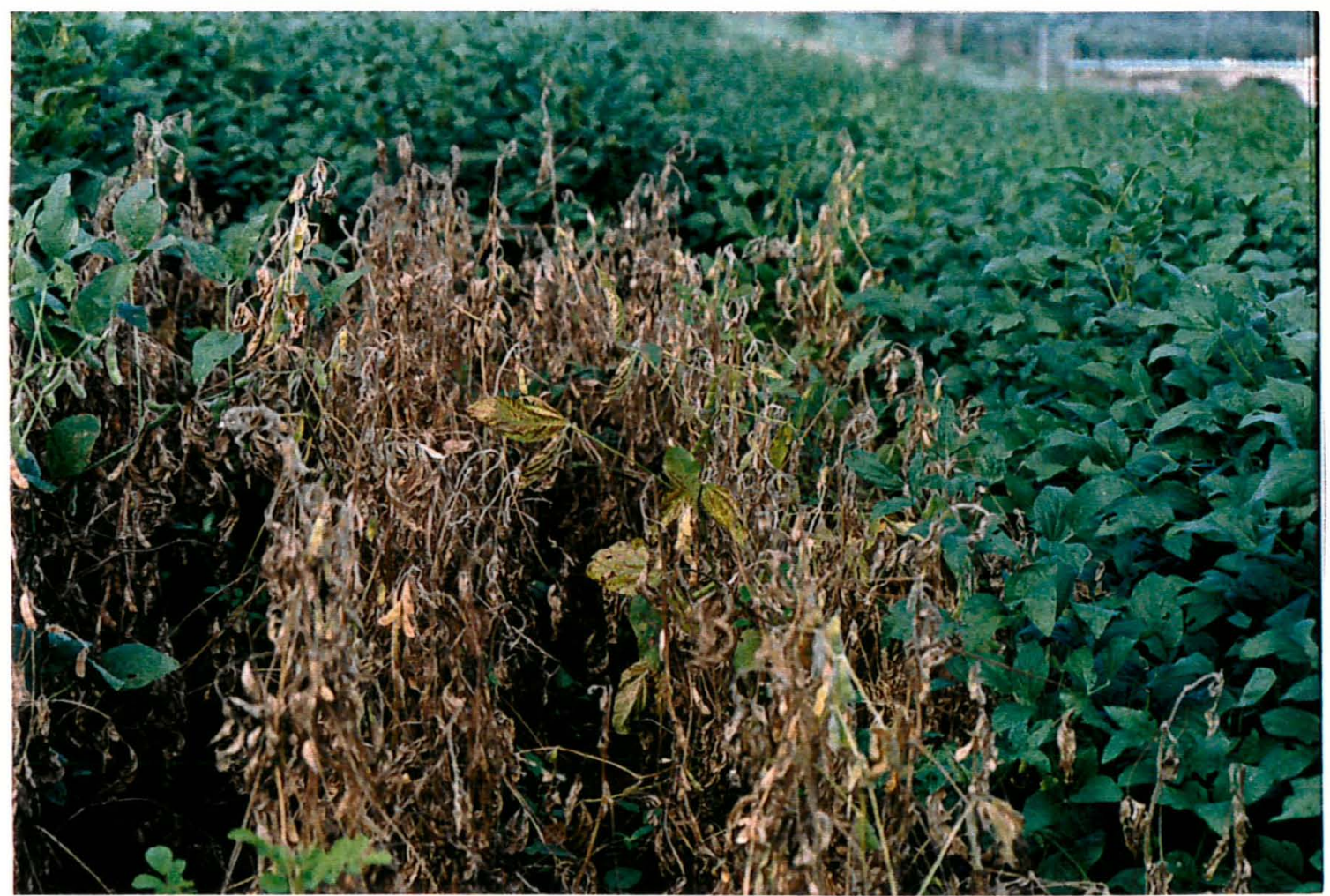

Figura 5. Reação ao cancro da haste da soja (CHS) no local ESALQ: parcela de plantas suscetíveis circundada por plantas sem sintomas da doença. Soja, Piracicaba, SP (semeadura em 06/11/96). 


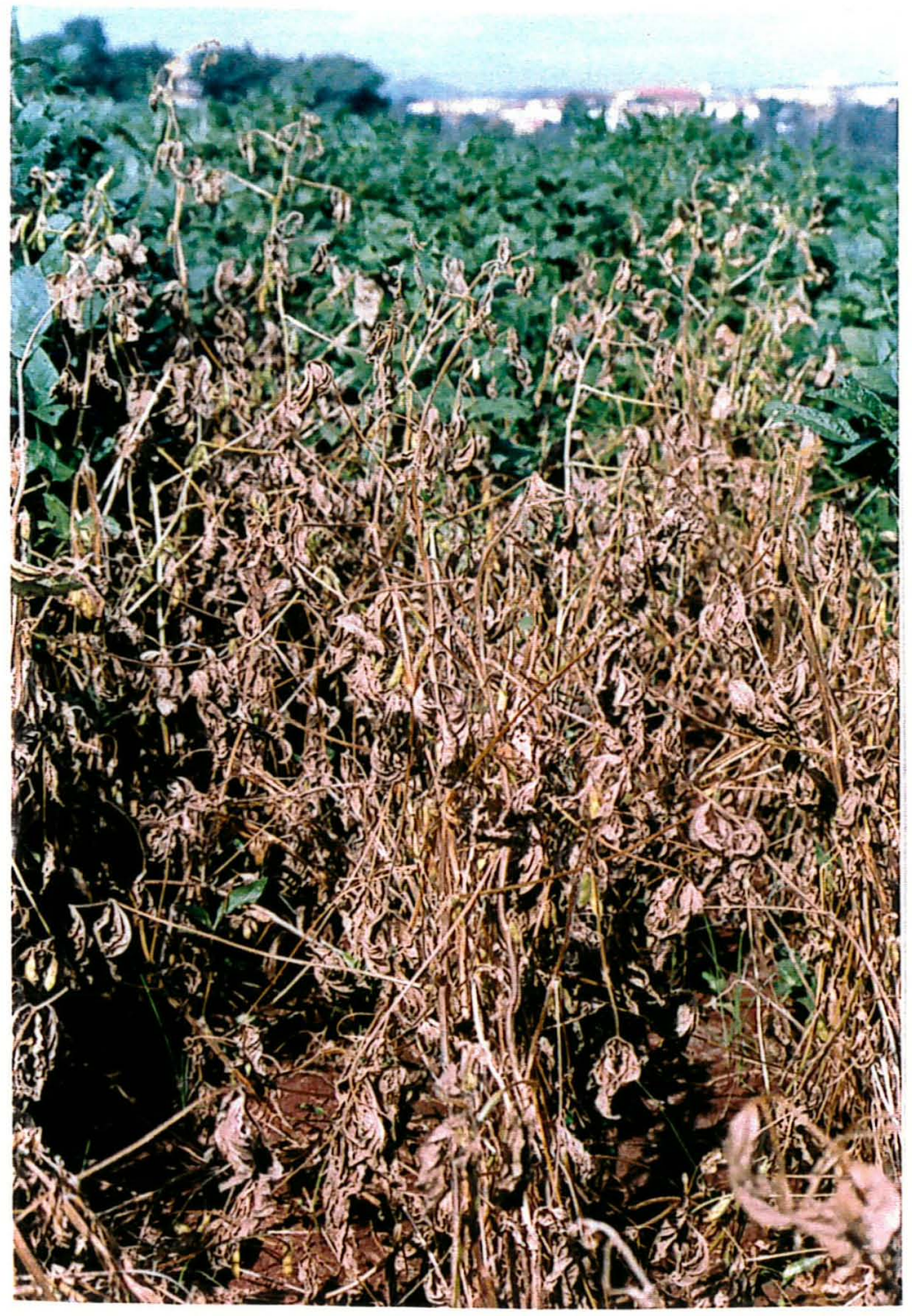

Figura 6. Reação ao cancro da haste da soja (CHS) no local Areão: na frente parcela com plantas suscetíveis e ao fundo plantas sem sintomas da doença. Soja, Piracicaba, SP (semeadura em 12/06/97). 
TABELAS 
Tabela 1. Identificação, genealogia, geração de endogamia, ciclo de maturação (CM) e programa de origem das linhagens experimentais avaliadas. Soja, Piracicaba, SP, 1998.

\begin{tabular}{|c|c|c|c|c|c|}
\hline $\mathbf{N}$ & Nㄴ USP & GENEALOGIA & GERACÁO & $\mathrm{CM}$ & PROGRAMA \\
\hline 1 & $93-1002$ & Paraná x IAC-Foscarin-31 ${ }^{\mathrm{a}}$ & $F_{12: 6}$ & $\mathbf{P}^{\prime}$ & $P G^{D}$ \\
\hline 2 & $93-1012$ & Paraná x Primavera & $F_{12: 6}$ & $\mathbf{P}$ & PG \\
\hline 3 & $93-1042$ & IAC-Foscarin-31 x Primavera ${ }^{a}$ & $F_{12: 6}$ & $\mathbf{P}$ & PG \\
\hline 4 & $93-1043$ & IAC-Foscarin-31 x Primavera ${ }^{a}$ & $F_{12: 6}$ & $\mathbf{P}$ & PG \\
\hline 5 & $93-1044$ & IAC-Foscarin-31 x Primavera ${ }^{a}$ & $F_{12: 6}$ & $\mathbf{P}$ & PG \\
\hline 6 & $93-1050$ & IAC-Foscarin-31 x Forrest ${ }^{\mathrm{m}}$ & $F_{12: 6}$ & $\mathbf{P}$ & PG \\
\hline 7 & $93-1051$ & IAC-Foscarin-31 x Forrest ${ }^{\mathrm{m}}$ & $F_{12: 6}$ & $\mathbf{P}$ & PG \\
\hline 8 & $93-1059$ & IAC-Foscarin-31 x SOC $81-79^{a}$ & $F_{12: 6}$ & $\mathbf{P}$ & PG \\
\hline 9 & $93-1069$ & Coker 136 x Primavera ${ }^{m}$ & $F_{12: 6}$ & $\mathbf{P}$ & PG \\
\hline 10 & $93-1072$ & Coker 136 x Primavera ${ }^{m}$ & $F_{12: 6}$ & $\mathbf{P}$ & PG \\
\hline 11 & $93-1075$ & Coker 136 x Década $^{m}$ & $F_{12: 6}$ & $\mathbf{P}$ & PG \\
\hline 12 & $93-1077$ & Coker $136 \times$ Forrest $^{m}$ & $F_{12: 6}$ & $\mathbf{P}$ & PG \\
\hline 13 & $93-1079$ & Coker $136 \times$ Forrest $^{\mathrm{m}}$ & $F_{12: 6}$ & $P$ & PG \\
\hline 14 & $93-1081$ & Coker 136 x FT $81-1835^{m}$ & $F_{12: 6}$ & $\mathbf{P}$ & PG \\
\hline 15 & $93-1101$ & Primavera x Forrest ${ }^{m}$ & $F_{12: 6}$ & $\mathbf{P}$ & PG \\
\hline 16 & $93-1103$ & Primavera $\times$ Forrest $^{\mathrm{m}}$ & $F_{12: 6}$ & $\mathbf{P}$ & PG \\
\hline 17 & $93-1107$ & Primavera $\times$ FT $81-1835^{\mathrm{a}}$ & $F_{12: 6}$ & $\mathbf{P}$ & PG \\
\hline 18 & $93-1109$ & Primavera $x$ SOC $81-79^{a}$ & $F_{12: 6}$ & $\mathbf{P}$ & PG \\
\hline 19 & $93-1121$ & Década x Forrest ${ }^{m}$ & $F_{12: 6}$ & $\mathbf{P}$ & PG \\
\hline 20 & $93-1122$ & Década x Forrest ${ }^{m}$ & $F_{12: 6}$ & $\mathbf{P}$ & PG \\
\hline 21 & $93-1131$ & Década x SOC 81-79 & $F_{12: 6}$ & $\mathbf{P}$ & PG \\
\hline 22 & $93-1142$ & Forrest x FT $81-1835^{m}$ & $F_{12: 6}$ & $\mathbf{P}$ & PG \\
\hline 23 & $93-1164$ & FT $81-1835 \times$ Hale $321^{m}$ & $F_{12: 6}$ & $\mathbf{P}$ & PG \\
\hline 24 & $93-1167$ & FT $81-1835 \times$ FT $81-2134^{a}$ & $F_{12: 6}$ & $\mathbf{P}$ & PG \\
\hline 25 & $93-1187$ & IAC-Foscarin-31 x Década ${ }^{a}$ & $F_{12: 6}$ & $\mathbf{P}$ & PG \\
\hline 26 & $93-1188$ & IAC-Foscarin-31 x Forrest $^{\mathrm{m}}$ & $F_{12: 6}$ & $\mathbf{P}$ & PG \\
\hline 27 & $93-1195$ & Coker 136 x Primavera ${ }^{\mathrm{m}}$ & $F_{12: 6}$ & $\mathbf{P}$ & PG \\
\hline 28 & $93-1203$ & Primavera $\times$ SOC $81-79^{a}$ & $F_{12: 6}$ & $\mathbf{P}$ & PG \\
\hline 29 & $94-1004$ & Paraná x Forrest ${ }^{m}$ & $F_{12: 6}$ & $\mathbf{P}$ & PG \\
\hline 30 & $94-1005$ & Paraná x Forrest ${ }^{m}$ & $F_{12: 6}$ & $\mathbf{P}$ & PG \\
\hline 31 & $94-1008$ & Paraná x SOC 81-79 & $F_{12: 6}$ & $\mathbf{P}$ & PG \\
\hline 32 & $94-1012$ & IAC-Foscarin-31 x Primavera ${ }^{a}$ & $F_{12: 6}$ & $\mathbf{P}$ & PG \\
\hline 33 & $94-1024$ & IAC-Foscarin-31 x Forrest ${ }^{m}$ & $F_{12: 6}$ & $\mathbf{P}$ & PG \\
\hline 34 & $94-1044$ & Coker $136 \times$ Hale $321^{e}$ & $F_{12: 6}$ & $\mathbf{P}$ & PG \\
\hline 35 & $94-1049$ & Coker $136 \times$ FT $81-2134^{m}$ & $F_{12: 6}$ & $\mathbf{P}$ & PG \\
\hline 36 & $94-1054$ & Primavera $x$ Forrest ${ }^{m}$ & $F_{12: 6}$ & $\mathbf{P}$ & PG \\
\hline 37 & $94-1055$ & Primavera x Forrest $^{m}$ & $F_{12: 6}$ & $\mathbf{P}$ & PG \\
\hline 38 & $94-1061$ & Primavera x FT $81-1835^{\mathrm{a}}$ & $F_{12: 6}$ & $\mathbf{P}$ & PG \\
\hline 39 & $94-1070$ & Primavera $x$ FT $81-2134^{a}$ & $F_{12: 6}$ & $\mathbf{P}$ & PG \\
\hline 40 & $94-1081$ & Década x FT 81-2134 & $F_{12: 6}$ & $\mathbf{P}$ & PG \\
\hline 41 & $94-1086$ & Década x FT 81-1835 & $F_{12: 6}$ & $\mathbf{P}$ & PG \\
\hline 42 & $94-1087$ & Forrest x FT 81-2134 ${ }^{m}$ & $F_{12: 6}$ & $P$ & PG \\
\hline 43 & $94-1097$ & FT $81-1835 \times$ FT $81-2134^{a}$ & $F_{12: 6}$ & $\mathbf{P}$ & PG \\
\hline
\end{tabular}


Tabela 1. Identificação, genealogia, geração de endogamia, ciclo de maturação (CM) e programa de origem das linhagens experimentais avaliadas. Soja, Piracicaba, SP, 1998.

\begin{tabular}{|c|c|c|c|c|c|}
\hline$N$ & Nㅡ USP & GENEALOGIA & GERACÃO & $\mathrm{CM}$ & PROGRAMA \\
\hline 44 & $93-1004$ & Paraná x IAC-Foscarin-31 & $F_{12: 3}$ & $\mathrm{SP}^{2}$ & PG \\
\hline 45 & $93-1052$ & IAC-Foscarin-31 x Forrest $^{\mathrm{m}}$ & $F_{12: 3}$ & SP & PG \\
\hline 46 & $93-1086$ & Coker 136 x SOC $81-79^{m}$ & $F_{12: 3}$ & SP & PG \\
\hline 47 & $93-1104$ & Primavera $x$ Forrest ${ }^{m}$ & $\mathbf{F}_{12: 3}$ & SP & PG \\
\hline 48 & $93-1106$ & Primavera x FT 81-1835 & $\mathbf{F}_{12: 3}$ & SP & PG \\
\hline 49 & $93-1119$ & Primavera x FT 81-2134 & $F_{12: 3}$ & SP & PG \\
\hline 50 & $93-1125$ & Década x FT $81-1835^{a}$ & $F_{12: 3}$ & SP & PG \\
\hline 51 & $93-1163$ & FT $81-1835 \times$ Hale $321^{m}$ & $\boldsymbol{F}_{12: 3}$ & SP & PG \\
\hline 52 & 93-1202 & Primavera $\times$ FT $81-1835^{a}$ & $F_{12: 3}$ & SP & PG \\
\hline 53 & $93-1211$ & FT $81-1835 \times$ Hale $321^{m}$ & $F_{12: 3}$ & SP & PG \\
\hline 54 & 93-2002 & Davis-1 x Bossier ${ }^{m}$ & $F_{8: 3}$ & SP & PG \\
\hline 55 & $93-2027$ & Davis-1 x Viçoja ${ }^{\mathrm{m}}$ & $F_{8: 3}$ & SP & PG \\
\hline 56 & 93-2072 & Bossier x Viçoja ${ }^{a}$ & $F_{8: 3}$ & SP & PG \\
\hline 57 & 93-2084 & Bossier x Viçoja ${ }^{a}$ & $F_{8: 3}$ & SP & PG \\
\hline 58 & $93-2100$ & Bossier x BR-1-Fosca ${ }^{a}$ & $F_{8: 3}$ & SP & PG \\
\hline 59 & $93-2103$ & Bossier x BR-1-Fosca ${ }^{a}$ & $F_{8: 3}$ & SP & PG \\
\hline 60 & $93-2104$ & Bossier x BR-1-Fosca ${ }^{a}$ & $F_{8: 3}$ & SP & PG \\
\hline 61 & $93-2140$ & Davis-1 x GO 81-11.646 ${ }^{m}$ & $F_{8: 3}$ & SP & PG \\
\hline 62 & 93-2142 & Davis-1 x GO 81-11.646 & $F_{8: 3}$ & SP & PG \\
\hline 63 & $93-2171$ & Davis-1 x SOC 81-228m & $F_{8: 3}$ & SP & PG \\
\hline 64 & $93-2180$ & Davis-1 x IAC-10 m & $F_{8: 3}$ & SP & PG \\
\hline 65 & $93-2250$ & Bossier $\times \mid A C-12^{a}$ & $F_{8: 3}$ & SP & PG \\
\hline 66 & $93-2259$ & Bossier $\times \mid A C-12^{a}$ & $F_{8: 3}$ & SP & PG \\
\hline 67 & $93-2294$ & Davis-1 x BR-1-Fosca ${ }^{m}$ & $F_{8: 3}$ & SP & PG \\
\hline 68 & $93-2302$ & Davis-1 x BR-1-Fosca ${ }^{m}$ & $F_{8: 3}$ & SP & PG \\
\hline 69 & $93-2306$ & 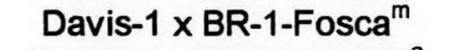 & $F_{8: 3}$ & SP & PG \\
\hline 70 & $93-2313$ & Bossier x GO 81-11.646 & $F_{8: 3}$ & SP & PG \\
\hline 71 & $93-2316$ & Bossier x GO 81-11.646 & $F_{8: 3}$ & SP & PG \\
\hline 72 & $93-2320$ & Bossier x GO 81-11.646 ${ }^{\mathrm{a}}$ & $F_{8: 3}$ & SP & PG \\
\hline 73 & $93-2329$ & Bossier x GO 81-11.646 ${ }^{a}$ & $F_{8: 3}$ & SP & PG \\
\hline 74 & $93-2419$ & Viçoja $\times 1 A C-1^{a}$ & $F_{8: 3}$ & SP & PG \\
\hline 75 & $93-2475$ & Viçoja x GO 81-11.646 ${ }^{\mathrm{a}}$ & $F_{8: 3}$ & SP & PG \\
\hline 76 & $93-2479$ & Viçoja x GO 81-11.646 ${ }^{\mathrm{a}}$ & $F_{8: 3}$ & SP & PG \\
\hline 77 & $93-2496$ & Viçoja x FT 81-2706 ${ }^{\mathrm{a}}$ & $F_{8: 3}$ & SP & PG \\
\hline 78 & $93-2529$ & IAC-10 x IAC-12 ${ }^{\mathrm{a}}$ & $F_{8: 3}$ & SP & PG \\
\hline 79 & $93-2565$ & IAC-10 x BR-1-Fosca ${ }^{a}$ & $F_{8: 3}$ & SP & PG \\
\hline 80 & $93-2580$ & $|A C-10 \times| A C-1^{a}$ & $F_{8: 3}$ & SP & PG \\
\hline 81 & $93-2590$ & $|A C-10 \times| A C-1^{a}$ & $F_{8: 3}$ & SP & PG \\
\hline 82 & $93-2667$ & $|A C-12 \times| A C-1^{a}$ & $F_{8: 3}$ & SP & PG \\
\hline 83 & $93-2675$ & $|A C-12 \times| A C-1^{a}$ & $F_{8: 3}$ & SP & PG \\
\hline 84 & $93-2680$ & $|A C-12 \times| A C-1^{a}$ & $\mathbf{F}_{8: 3}$ & SP & PG \\
\hline 85 & $93-2693$ & IAC-12 x BR-1-Fosca ${ }^{a}$ & $F_{8: 3}$ & SP & PG \\
\hline 86 & $93-2697$ & IAC-12 $\times$ BR-1-Fosca ${ }^{a}$ & $F_{8: 3}$ & SP & PG \\
\hline
\end{tabular}


Tabela 1. Identificação, genealogia, geração de endogamia, ciclo de maturação (CM) e programa de origem das linhagens experimentais avaliadas. Soja, Piracicaba, SP, 1998.

\begin{tabular}{|c|c|c|c|c|c|}
\hline $\mathbf{N}$ & $N=$ USP & GENEALOGIA & GERACÁO & CM & PROGRAMA \\
\hline $\begin{array}{l}87 \\
88\end{array}$ & $\begin{array}{l}93-2699 \\
93-2727\end{array}$ & $\begin{array}{l}\text { IAC-12 x BR-1-Fosca }{ }^{a} \\
\text { IAC-12 } 1 \text { FT } 81-2706^{a}\end{array}$ & $\begin{array}{l}F_{8: 3} \\
F_{8: 3}\end{array}$ & $\begin{array}{l}\text { SP } \\
\text { SP }\end{array}$ & $\begin{array}{l}\text { PG } \\
P G\end{array}$ \\
\hline 89 & $93-2730$ & IAC-12 x FT 81-2706 ${ }^{a}$ & $F_{8.3}$ & SP & PG \\
\hline 90 & $93-2738$ & IAC-12 x FT $81-2706^{a}$ & $F_{8.3}$ & SP & PG \\
\hline 91 & $93-2756$ & IAC-12 $\times$ SOC $81-228^{a}$ & $F_{8: 3}$ & SP & PG \\
\hline 92 & $93-2781$ & IAC-1 x BR-1-Fosca ${ }^{a}$ & $F_{8: 3}$ & SP & PG \\
\hline 93 & $93-2790$ & IAC-1 x BR-1-Fosca ${ }^{a}$ & $F_{8: 3}^{0.3}$ & SP & PG \\
\hline 94 & $93-2857$ & IAC-1 $\times$ SOC $81-228^{a}$ & $F_{8.3}$ & SP & PG \\
\hline 95 & $93-2858$ & IAC-1 x SOC $81-228^{a}$ & $F_{8: 3}$ & SP & PG \\
\hline 96 & $93-2859$ & BR-1-Fosca x FT 81-2706 & $F_{8.3}$ & SP & PG \\
\hline 97 & $93-2881$ & GO $81-11.646 \times$ FT $81-2706^{a}$ & $F_{8.3}$ & SP & PG \\
\hline 98 & $93-2897$ & GO $81-11.646$ x FT $81-2706^{a}$ & $F_{8: 3}$ & SP & PG \\
\hline 99 & $93-2899$ & GO $81-11.646$ x FT $81-2706^{a}$ & $F_{8: 3}$ & SP & PG \\
\hline 100 & $93-2900$ & GO $81-11.646$ x FT $81-2706^{a}$ & $F_{8: 3}$ & SP & PG \\
\hline 101 & $93-2909$ & BR-1-Fosca $\times$ SOC $81-228^{a}$ & $F_{8: 3}^{0.5}$ & SP & PG \\
\hline 102 & $93-2916$ & BR-1-Fosca $\times$ SOC $81-228^{a}$ & $F_{8: 3}$ & SP & PG \\
\hline 103 & $93-2927$ & SOC $81-228 \times$ FT $81-2706^{a}$ & $F_{8: 3}$ & SP & PG \\
\hline 104 & $93-2954$ & BR-1-Fosca x GO 81-11.646 & $F_{8 \cdot 3}$ & SP & PG \\
\hline 105 & $94-1017$ & IAC-Foscarin-31 x Primavera & $F_{12: 3}$ & SP & PG \\
\hline 106 & $94-1080$ & Década x FT 81-2134 & $F_{12: 3}$ & SP & PG \\
\hline 107 & $93-2258$ & Bossier x $1 A C-12^{a}$ & $F_{8: 3}$ & $i^{3-}$ & $P G$ \\
\hline 108 & $93-2266$ & Bossier $\times \mid A C-1^{a}$ & $F_{8: 3}$ & i & PG \\
\hline 109 & $93-2270$ & Bossier $\times \mid A C-1^{a}$ & $F_{8: 3}$ & $i$ & PG \\
\hline 110 & $93-2351$ & Bossier $x$ SOC $81-228^{a}$ & $F_{8: 3}$ & i & PG \\
\hline 111 & $93-2353$ & Davis-1 $\times 1 A C-12^{m}$ & $F_{8: 3}$ & 1 & PG \\
\hline 112 & $93-2393$ & Viçoja $\times \mid A C-10^{a}$ & $F_{8: 3}$ & i & PG \\
\hline 113 & $93-2418$ & Viçoja x IAC-12 & $F_{8: 3}$ & 1 & PG \\
\hline 114 & $93-2514$ & Viçoja $\times$ FT 81-2706 ${ }^{a}$ & $F_{8: 3}$ & 1 & PG \\
\hline 115 & $93-2521$ & Viçoja $\times$ FT 81-2706 ${ }^{a}$ & $F_{8: 3}$ & I & PG \\
\hline 116 & $93-2530$ & $|A C-10 \times| A C-12^{a}$ & $F_{8: 3}$ & 1 & PG \\
\hline 117 & $93-2594$ & IAC-10 x BR-1-Fosca ${ }^{a}$ & $F_{8: 3}$ & 1 & PG \\
\hline 118 & $93-2623$ & IAC-10 x SOC $81-228^{a}$ & $F_{8: 3}$ & i & PG \\
\hline 119 & $93-2643$ & IAC-10 x FT $81-2706^{a}$ & $F_{8: 3}$ & 1 & PG \\
\hline 120 & $93-2674$ & $|A C-12 \times| A C-1^{a}$ & $F_{8: 3}$ & i & PG \\
\hline 121 & $93-2686$ & IAC-12 $\times$ BR-1-Fosca ${ }^{a}$ & $F_{8: 3}$ & i & PG \\
\hline 122 & $93-2722$ & IAC-12 x GO 81-11.646 & $F_{8: 3}$ & i & PG \\
\hline 123 & $93-2725$ & IAC-12 x GO 81-11.646 ${ }^{\mathrm{a}}$ & $F_{8: 3}$ & 1 & PG \\
\hline 124 & $93-2753$ & IAC-12 x SOC $81-228^{a}$ & $F_{8: 3}$ & 1 & PG \\
\hline 125 & $93-2755$ & IAC-12 x SOC $81-228^{a}$ & $F_{8: 3}$ & 1 & PG \\
\hline 126 & $93-2802$ & IAC-1 x GO 81-11.646 ${ }^{\mathrm{a}}$ & $F_{8: 3}$ & 1 & PG \\
\hline 127 & $93-2825$ & IAC-1 x FT 81-2706 ${ }^{a}$ & $F_{8: 3}$ & 1 & PG \\
\hline 128 & $93-2850$ & IAC-1 x SOC $81-228^{a}$ & $F_{8: 3}$ & 1 & PG \\
\hline 129 & $93-2870$ & BR-1-Fosca x FT 81-2706 ${ }^{a}$ & $F_{8: 3}$ & i & PG \\
\hline
\end{tabular}


Tabela 1. Identificação, genealogia, geração de endogamia, ciclo de maturação (CM) e programa de origem das linhagens experimentais avaliadas. Soja, Piracicaba, SP, 1998.

\begin{tabular}{|c|c|c|c|c|c|}
\hline $\mathbf{N}$ & № USP & GENEALOGIA & GERAÇÃO & $\mathrm{CM}$ & PROGRAMA \\
\hline $\begin{array}{l}130 \\
131\end{array}$ & $\begin{array}{l}93-5082 \\
93-5243\end{array}$ & $\begin{array}{c}\text { GO } 81-11.646 \times \text { SOC } 81-228^{a} \\
\text { FT } 81-2706 \times \text { PI } 371610^{m}\end{array}$ & $\begin{array}{l}F_{10: 3} \\
F_{10: 3}\end{array}$ & 1 & $\begin{array}{l}P G \\
P O^{C}\end{array}$ \\
\hline 132 & $93-5262$ & PI $371610 \times$ Paraná-s ${ }^{m}$ & $F_{10: 3}$ & i & PO \\
\hline 133 & $93-5423$ & SOC $81-76 \times$ Foster $^{m}$ & $F_{10: 3}$ & i & PO \\
\hline 134 & $93-5539$ & Paranagoiana $\times$ Jackson-4028-s ${ }^{m}$ & $F_{10: 3}$ & I & PO \\
\hline 135 & $93-5544$ & Paranagoiana $x$ Jackson-4028-s ${ }^{m}$ & $F_{10: 3}$ & i & PO \\
\hline 136 & $93-5549$ & Jackson-4028-s x FT 81-2129m & $F_{10: 3}$ & i & PO \\
\hline 137 & $93-5552$ & Jackson-4028-s x FT 81-2129 ${ }^{\mathrm{m}}$ & $F_{10: 3}$ & I & PO \\
\hline 138 & $93-5560$ & FT $81-2129 \times$ Cobb $^{m}$ & $F_{10: 3}$ & I & PO \\
\hline 139 & $93-5582$ & Cobb $\times$ BR-8 ${ }^{m}$ & $F_{10: 3}$ & 1 & PO \\
\hline 140 & $93-5585$ & Cobb $\times$ BR- $8^{m}$ & $F_{10: 3}$ & I & PO \\
\hline 141 & $93-5586$ & Cobb $\times$ BR-8 ${ }^{m}$ & $F_{10: 3}$ & I & PO \\
\hline 142 & 93-5597 & Cobb $\times$ BR-8 ${ }^{m}$ & $F_{10: 3}$ & I & PO \\
\hline 143 & $93-5690$ & Bienville $\times$ UFV-Araguaia ${ }^{a}$ & $F_{10: 3}$ & I & PO \\
\hline 144 & 93-5692 & Foster x FT 79-3408 ${ }^{m}$ & $F_{10: 3}$ & I & PO \\
\hline 145 & 93-5699 & FT $79-3408 \times A \times 53-55-s^{m}$ & $F_{10: 3}$ & 1 & PO \\
\hline 146 & $93-5720$ & UFV-Araguaia $\times$ Bossier-s ${ }^{a}$ & $F_{10: 3}$ & I & PO \\
\hline 147 & 93-5735 & AX 53-55-s $\times$ Paranagoiana ${ }^{m}$ & $F_{10: 3}$ & I & PO \\
\hline 148 & $93-5750$ & Bossier-s x UFV-2 ${ }^{\mathrm{a}}$ & $F_{10: 3}$ & I & PO \\
\hline 149 & $93-5751$ & Bossier-s x UFV-2 ${ }^{\mathrm{a}}$ & $F_{10: 3}$ & I & PO \\
\hline 150 & $93-5785$ & UFV-2 x GO 81-8491 ${ }^{a}$ & $F_{10: 3}$ & I & PO \\
\hline 151 & $93-5843$ & BR 80-15725-B-s x Planalto-s ${ }^{a}$ & $F_{10: 3}$ & I & PO \\
\hline 152 & $93-5860$ & BR 80-15725-B-s x Planalto-s ${ }^{a}$ & $F_{10: 3}$ & I & PO \\
\hline 153 & $93-5884$ & Planalto-s x GO 81-11.094 & $F_{10: 3}$ & I & PO \\
\hline 154 & 93-5912 & GO 81-11.094 x BR-11 ${ }^{\mathrm{a}}$ & $F_{10: 3}$ & I & PO \\
\hline 155 & $93-5980$ & FT-8 $\times$ OC $79-7^{a}$ & $F_{10: 3}$ & 1 & PO \\
\hline 156 & $93-3086$ & IAC-4 X IAC-11 & $F_{11: 6}$ & $\mathbf{S} T^{4}$ & $P G$ \\
\hline 157 & $93-3230$ & EMGOPA-301 $\times 1 A C-8^{a}$ & $F_{11: 6}$ & ST & PG \\
\hline 158 & $93-3385$ & IAC-6 x Santa Rosa ${ }^{a}$ & $F_{11: 6}$ & ST & PG \\
\hline 159 & $93-3389$ & Cristalina-s $\times \mid A C-5^{a}$ & $F_{11: 6}$ & ST & PG \\
\hline 160 & $93-3396$ & 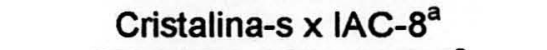 & $F_{11: 6}$ & ST & PG \\
\hline 161 & 93-3402 & EMGOPA-301 $\times 1 A C-6^{a}$ & $F_{11: 6}$ & ST & PG \\
\hline 162 & $93-3452$ & IAC-11 $\times$ SS- $1^{\mathrm{a}}$ & $F_{11: 6}$ & ST & PG \\
\hline 163 & $93-3527$ & EMGOPA-301 $\times 1 A C-4^{a}$ & $F_{11: 6}$ & ST & PG \\
\hline 164 & $93-3550$ & $|A C-8 \times| A C-11^{a}$ & $F_{11: 6}$ & ST & PG \\
\hline 165 & $93-5263$ & PI 371610 x Paraná-s ${ }^{m}$ & $F_{10: 3}$ & ST & PO \\
\hline 166 & 93-5316 & FT-2 x N 82-2764-s ${ }^{m}$ & $F_{10: 3}$ & ST & PO \\
\hline 167 & 93-5391 & Wright $\times$ SOC $81-76^{m}$ & $F_{10: 3}$ & ST & PO \\
\hline 168 & $93-5410$ & SOC $81-76 \times$ Foster ${ }^{m}$ & $F_{10: 3}$ & ST & PO \\
\hline 169 & 93-5419 & SOC $81-76$ x Foster ${ }^{m}$ & $F_{10: 3}$ & ST & PO \\
\hline 170 & $93-5513$ & AX 53-55-s x Paranagoianam & $F_{10: 3}$ & ST & PO \\
\hline 171 & 93-5537 & Paranagoiana $\times$ Jackson-4028-s ${ }^{m}$ & $F_{10: 3}$ & ST & PO \\
\hline 172 & $93-5580$ & Cobb $\times$ BR-8 ${ }^{m}$ & $F_{10: 3}$ & ST & PO \\
\hline
\end{tabular}


Tabela 1. Identificação, genealogia, geração de endogamia, ciclo de maturação (CM) e programa de origem das linhagens experimentais avaliadas. Soja, Piracicaba, SP, 1998.

\begin{tabular}{|c|c|c|c|c|c|}
\hline $\mathbf{N}$ & NNo USP & GENEALOGIA & GERAÇA & CM & PROGRAMA \\
\hline 173 & $93-5672$ & 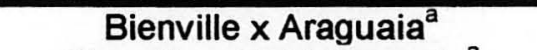 & $F_{10: 3}$ & ST & $\mathrm{PO}$ \\
\hline 174 & 93-5684 & Bienville $\times$ UFV-Araguaia ${ }^{a}$ & $F_{10: 3}$ & ST & PO \\
\hline 175 & 93-5687 & Bienville $\times$ UFV-Araguaia ${ }^{a}$ & $F_{10: 3}$ & ST & PO \\
\hline 176 & $93-5712$ & UFV-Araguaia x Bossier-s ${ }^{a}$ & $F_{10: 3}$ & ST & PO \\
\hline 177 & $93-5723$ & UFV-Araguaia x Bossier-s ${ }^{a}$ & $F_{10: 3}$ & ST & PO \\
\hline 178 & 93-5752 & Bossier-s x UFV-2 ${ }^{\mathrm{a}}$ & $F_{10: 3}$ & ST & PO \\
\hline 179 & 93-5756 & Bossier-s $\times$ UFV- $2^{a}$ & $F_{10: 3}$ & ST & PO \\
\hline 180 & 93-5772 & Bossier-s x UFV-2 ${ }^{\mathrm{a}}$ & $F_{10: 3}$ & ST & PO \\
\hline 181 & 93-5779 & UFV-2 x GO $81-8491^{a}$ & $F_{10: 3}$ & ST & PO \\
\hline 182 & 93-5791 & UFV-2 x GO $81-8491^{a}$ & $F_{10: 3}$ & ST & PO \\
\hline 183 & $93-5802$ & UFV-2 x GO $81-8491^{a}$ & $F_{10: 3}$ & ST & PO \\
\hline 184 & $93-5819$ & GO $81-8491$ x BR 80-15725-B-s ${ }^{a}$ & $F_{10: 3}$ & ST & PO \\
\hline 185 & 93-5834 & GO $81-8491$ x BR 80-15725-B-s ${ }^{a}$ & $F_{10: 3}$ & ST & PO \\
\hline 186 & $93-5847$ & BR 80-15725-B-s x Planalto-s ${ }^{a}$ & $F_{10: 3}$ & ST & PO \\
\hline 187 & $93-5872$ & Planalto-s x GO 81-11094 & $F_{10: 3}$ & ST & PO \\
\hline 188 & 93-5875 & Planalto-s x GO 81-11094a & $F_{10: 3}$ & ST & PO \\
\hline
\end{tabular}

': Precoce; ${ }^{2}$ : Semi-precoce; ${ }^{3}:$ Intermediário; ${ }^{4}$ : Semi-tardio.

a. Cruzamento adaptado (parental adaptado $x$ parental adaptado).

m: Cruzamento misto (parental adaptado x parental exótico).

${ }^{\mathrm{b}}$ : Produtividade de grãos; ${ }^{\mathrm{c}}$ : Produtividade de óleo.

O sufixo s observado em alguns genótipos refere-se à seleção de uma planta do genótipo que apresentou teor de óleo superior. 
Tabela 2. Esquema da análise de variância para as testemunhas em blocos ao acaso, com repetições subdivididas em conjuntos experimentais, ao nível de parcelas, e respectivas esperanças matemáticas dos quadrados médios.

\begin{tabular}{lcclc}
\hline \multicolumn{1}{c}{ F. VARIAÇÃO } & G.L. & Q.M. & \multicolumn{1}{c}{$E(Q . M)}$. & $F$ \\
\hline Repetições (R) & $r-1$ & $Q_{1}$ & $\sigma_{e}^{2}+C T \sigma_{r}^{2}$ & $Q_{1} / Q_{5}$ \\
Conjuntos (C) & $c-1$ & $Q_{2}$ & $\sigma_{e}^{2}+R T \sigma_{c}^{2}$ & $Q_{2} / Q_{5}$ \\
Testemunhas (T) & $t-1$ & $Q_{3}$ & $\sigma_{e}^{2}+R \sigma_{c t}^{2}+R C V_{t}$ & $Q_{3} / Q_{4}$ \\
C x T & $(c-1)(t-1)$ & $Q_{4}$ & $\sigma_{e}^{2}+R \sigma_{c t}^{2}$ & $Q_{4} Q_{5}$ \\
Resíduo & $r(c-1)(t-1)$ & $Q_{5}$ & $\sigma_{e}^{2}$ & \\
\hline TOTAL & $(\mathrm{rtc})-1$ & & & \\
\hline
\end{tabular}

Tabela 3. Esquema da análise de variância conjunta para as testemunhas em blocos ao acaso, com repetições subdivididas em conjuntos experimentais, ao nível de parcelas, e respectivas esperanças matemáticas dos quadrados médios.

\begin{tabular}{|c|c|c|c|c|}
\hline F. VARIAÇÃO & G.L. & Q.M. & $E(Q . M)$. & $F$ \\
\hline Locais (L) & $1-1$ & $Q_{1}$ & $\sigma_{\mathrm{e}}^{2}+\mathrm{RT} \sigma_{\mathrm{kc}}^{2}+\mathrm{CT} \sigma_{\mathrm{r}(\mathrm{l})}^{2}+\mathrm{RCV}$ & $\frac{Q_{1}+Q_{9}}{Q_{2}+Q_{7}}$ \\
\hline Repetições (R)/ L & $I(r-1)$ & $Q_{2}$ & $\sigma_{e}^{2}+C T \sigma_{r(1)}^{2}$ & $Q_{2} / Q_{9}$ \\
\hline Conjuntos (C) & $(c-1)$ & $Q_{3}$ & $\sigma_{e}^{2}+L R T \sigma_{c}^{2}$ & $Q_{3} / Q_{9}$ \\
\hline Testemunhas ( $T$ ) & $t-1$ & $\mathbf{Q}_{4}$ & $\sigma_{e}^{2}+L R \sigma_{c t}^{2}+L R C V_{t}$ & $Q_{4} / Q_{5}$ \\
\hline $\mathrm{C} \times \mathrm{T}$ & $(c-1)(t-1)$ & $Q_{5}$ & $\sigma_{e}^{2}+L R \sigma_{c t}^{2}$ & $Q_{5} / Q_{9}$ \\
\hline$L \times T$ & $(I-1)(t-1)$ & $Q_{6}$ & $\sigma_{e}^{2}+R \sigma_{l t t}^{2}+R C V_{t t}$ & $Q_{6} / Q_{8}$ \\
\hline $\mathrm{L} \times \mathrm{C}$ & $(I-1)(c-1)$ & $Q_{7}$ & $\sigma_{e}^{2}+R T \sigma_{k}^{2}$ & $Q_{7} / Q_{9}$ \\
\hline$L \times C \times T$ & $(\mathrm{l}-1)(\mathrm{c}-1)(\mathrm{t}-1)$ & $Q_{8}$ & $\sigma_{e}^{2}+R \sigma_{l c t}^{2}$ & $Q_{8} / Q_{9}$ \\
\hline Resíduo médio & $\operatorname{Ir}(c-1)(t-1)$ & $Q_{9}$ & $\sigma_{e}^{2}$ & \\
\hline TOTAL & (Irct) - 1 & & & \\
\hline
\end{tabular}


Tabela 4. Esquema da análise de variância para as linhagens experimentais em blocos ao acaso, ao nível de parcelas, e respectivas esperanças matemáticas dos quadrados médios

\begin{tabular}{lccll}
\hline F. VARIAÇÃO & G.L. & Q.M. & $E(Q . M)$. & \multicolumn{1}{c}{. } \\
\hline Repetições (R) & $r-1$ & $Q_{1}$ & $\sigma_{e}^{2}+G \sigma_{r}^{2}$ & $Q_{1} / Q_{3}$ \\
Linhagens (G) & $g-1$ & $Q_{2}$ & $\sigma_{e}^{2}+R V_{g}$ & $Q_{2} / Q_{3}$ \\
Resíduo & $(r-1)(g-1)$ & $Q_{3}$ & $\sigma_{e}^{2}$ & \\
\hline TOTAL & $(r g)-1$ & & & \\
\hline
\end{tabular}

Tabela 5. Esquema da análise conjunta de variância para as linhagens experimentais, em blocos ao acaso, ao nível de parcelas, e respectivas esperanças matemáticas dos quadrados médios.

\begin{tabular}{|c|c|c|c|c|}
\hline F. VARIAÇÃO & G.L. & Q.M. & E(Q.M.) & $F$ \\
\hline Locais (L) & $1-1$ & $Q_{1}$ & $\sigma_{e}^{2}+G \sigma_{r(1)}^{2}+R G V_{1}$ & $Q_{1} / Q_{2}$ \\
\hline Repetições (R)/L & $I(r-1)$ & $\mathbf{Q}_{2}$ & $\sigma_{e}^{2}+G \sigma_{r(1)}^{2}$ & $Q_{2} / Q_{5}$ \\
\hline Linhagens (G) & $g-1$ & $Q_{3}$ & $\sigma_{e}^{2}+\operatorname{LRV}_{g}$ & $Q_{3} / Q_{5}$ \\
\hline$G \times L$ & $(g-1)(\mid-1)$ & $Q_{4}$ & $\sigma_{e}^{2}+R V_{l g}$ & $Q_{4} / Q_{5}$ \\
\hline Resíduo médio ${ }^{1}$ & $\mathrm{I}(\mathrm{g}-1)(\mathrm{r}-1)$ & $Q_{5}$ & $\sigma_{e}^{2}$ & \\
\hline TOTAL & $(\mathrm{rgl})-1$ & & & \\
\hline
\end{tabular}

1: Envolve os quadrados médios dos resíduos para testemunhas e linhagens, ponderados por seus respectivos graus de liberdade. 

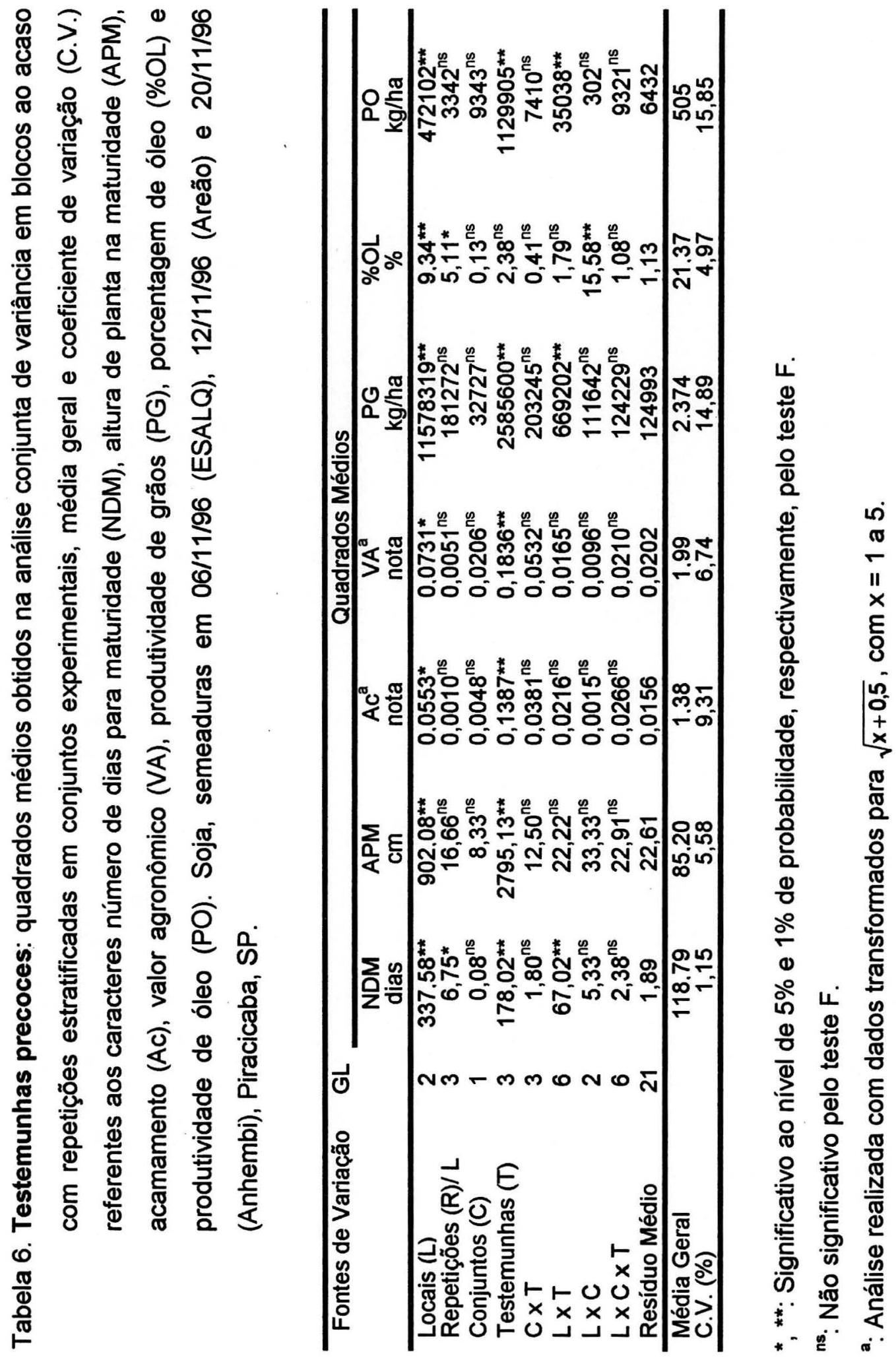

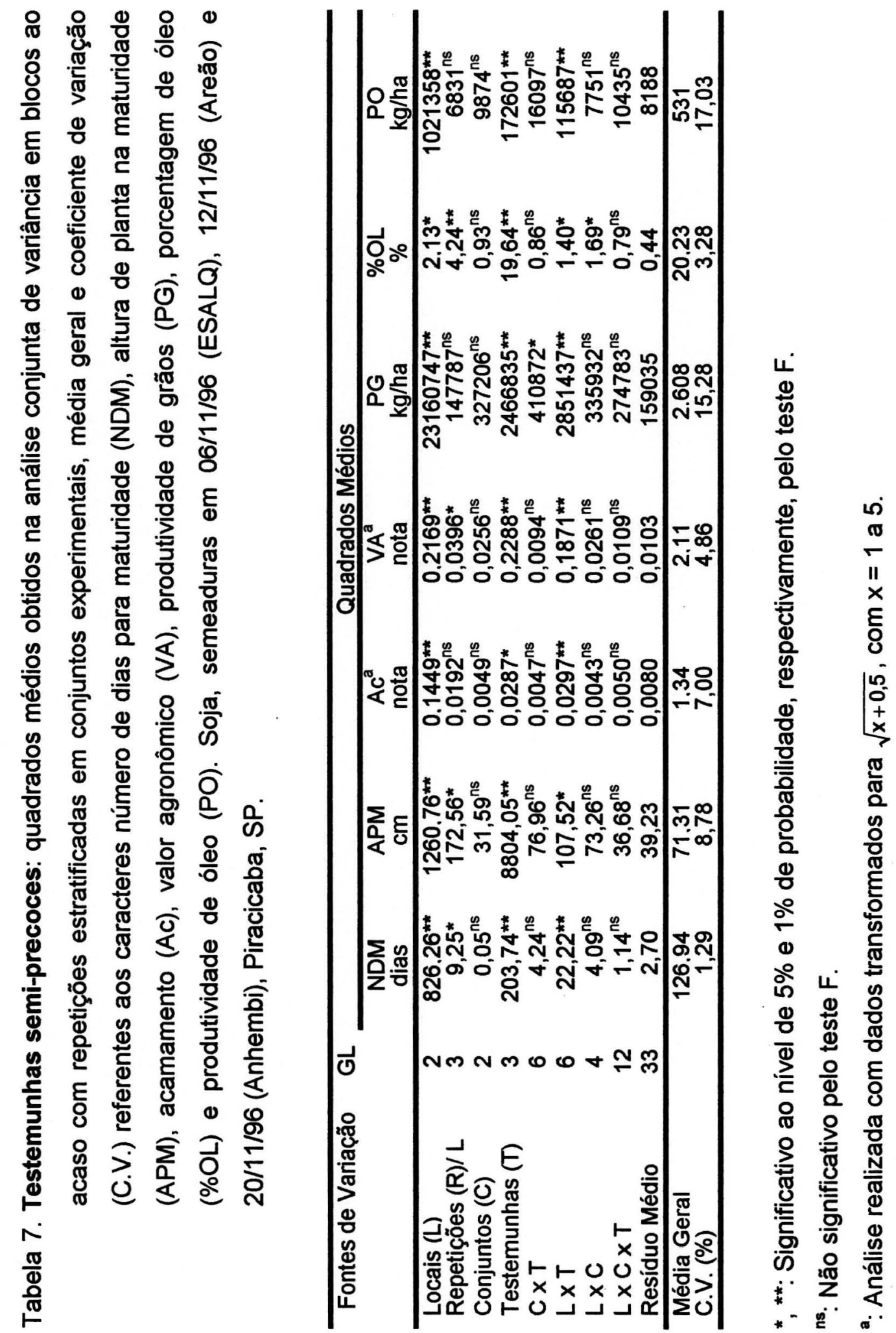


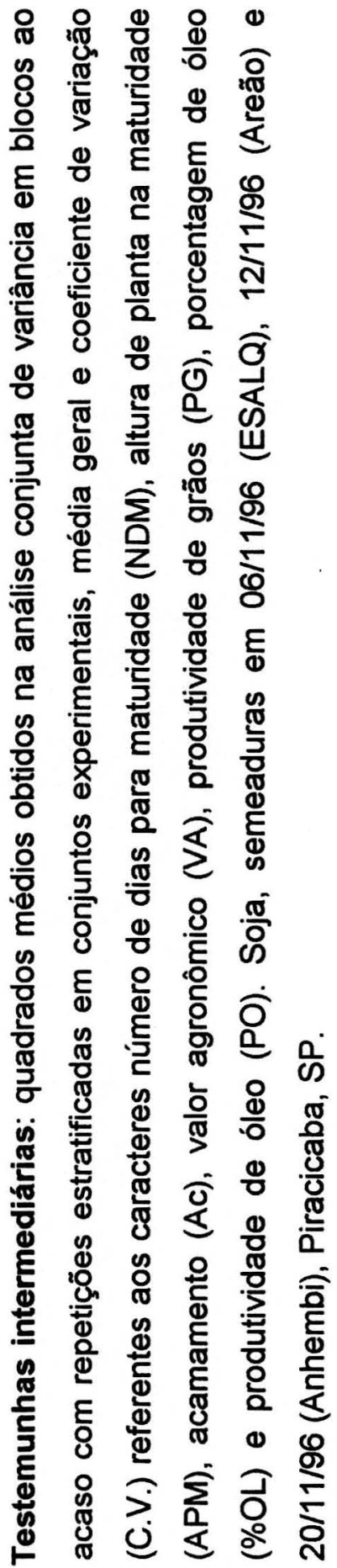

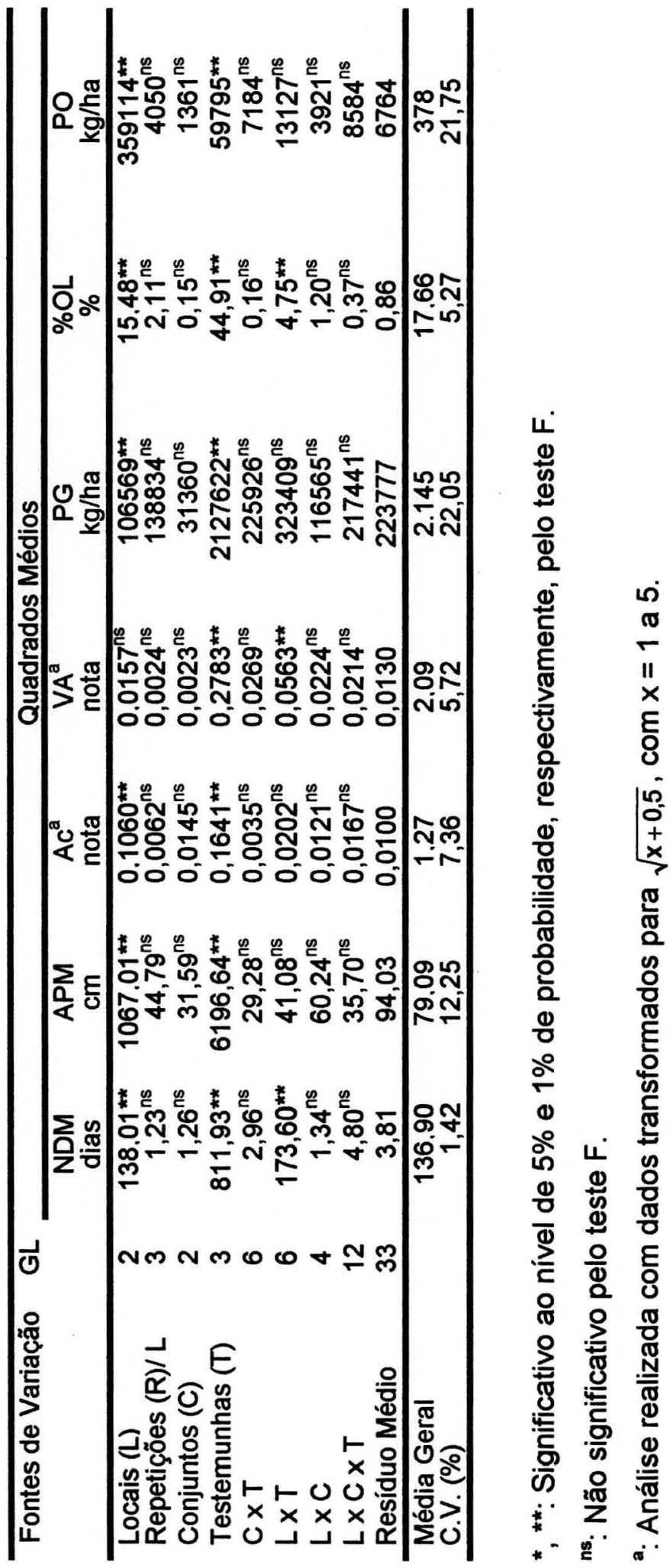




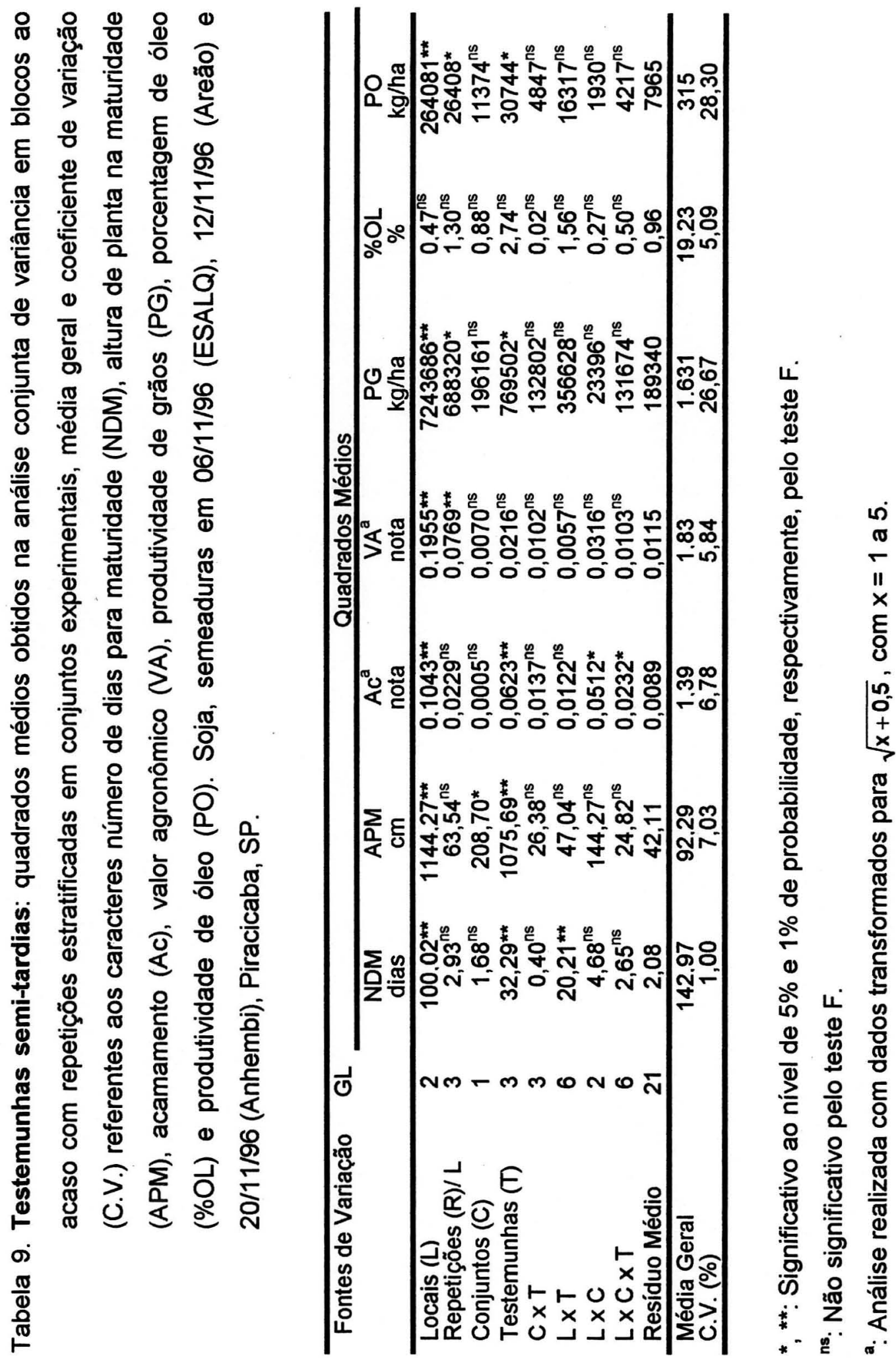




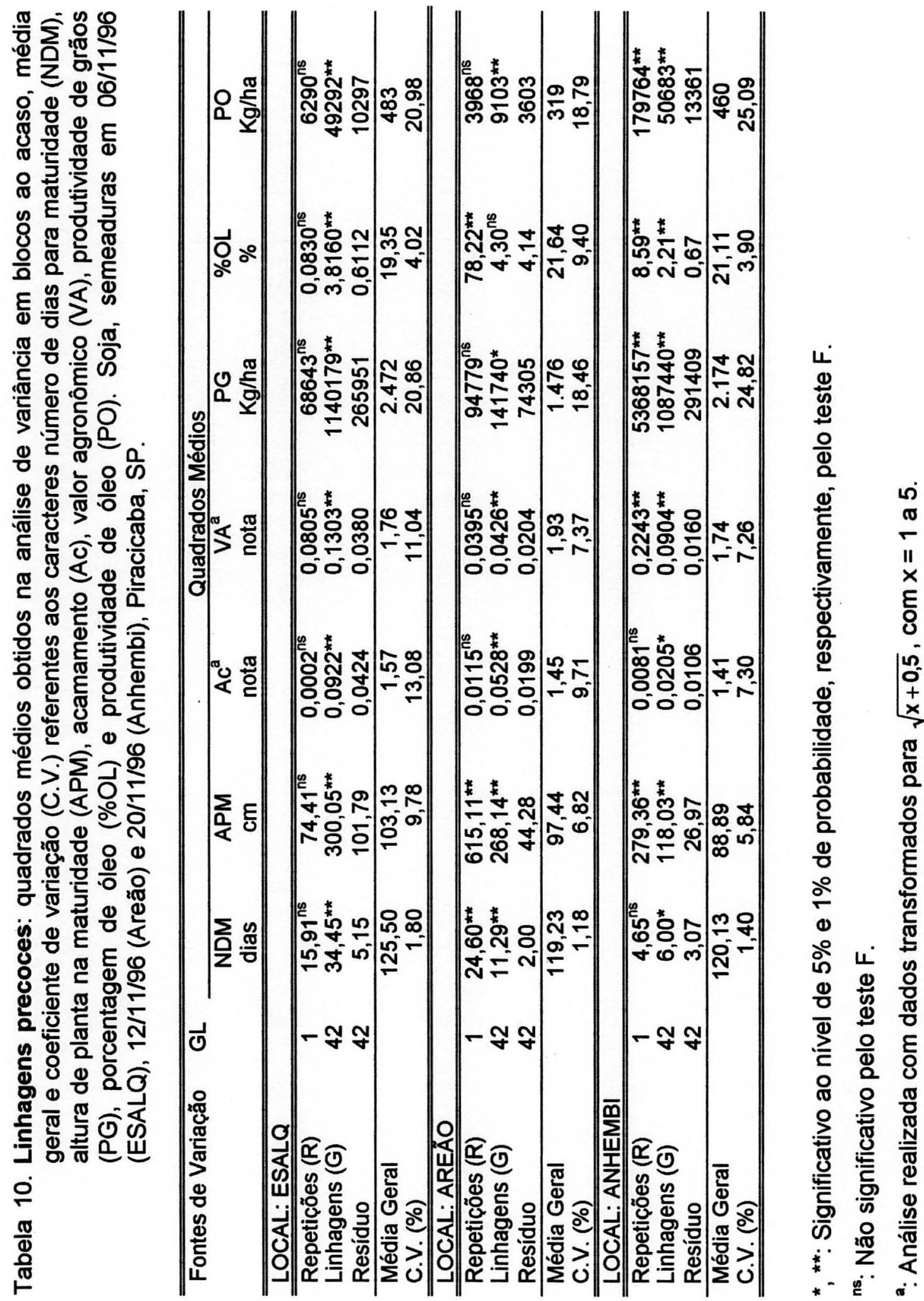




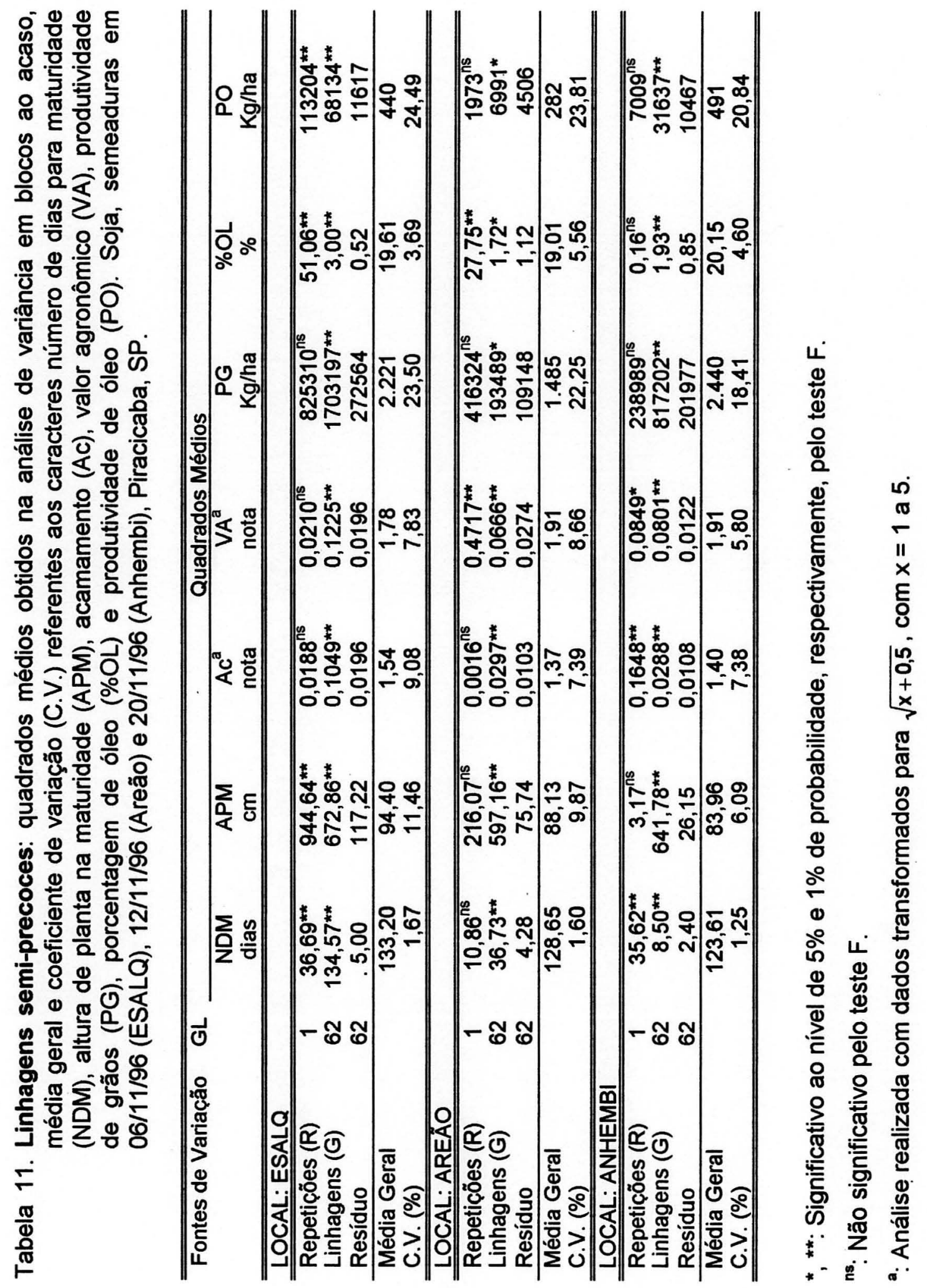




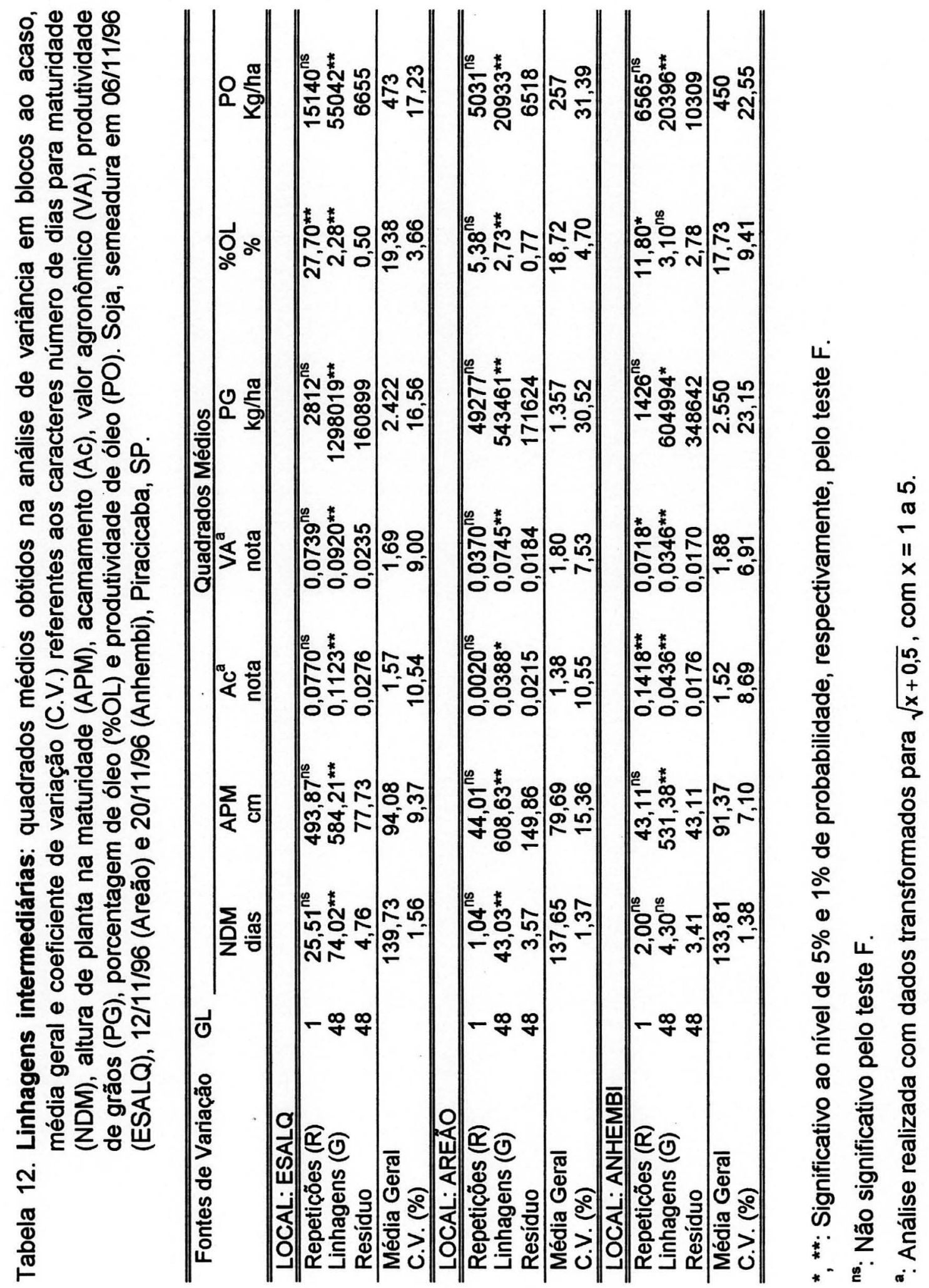




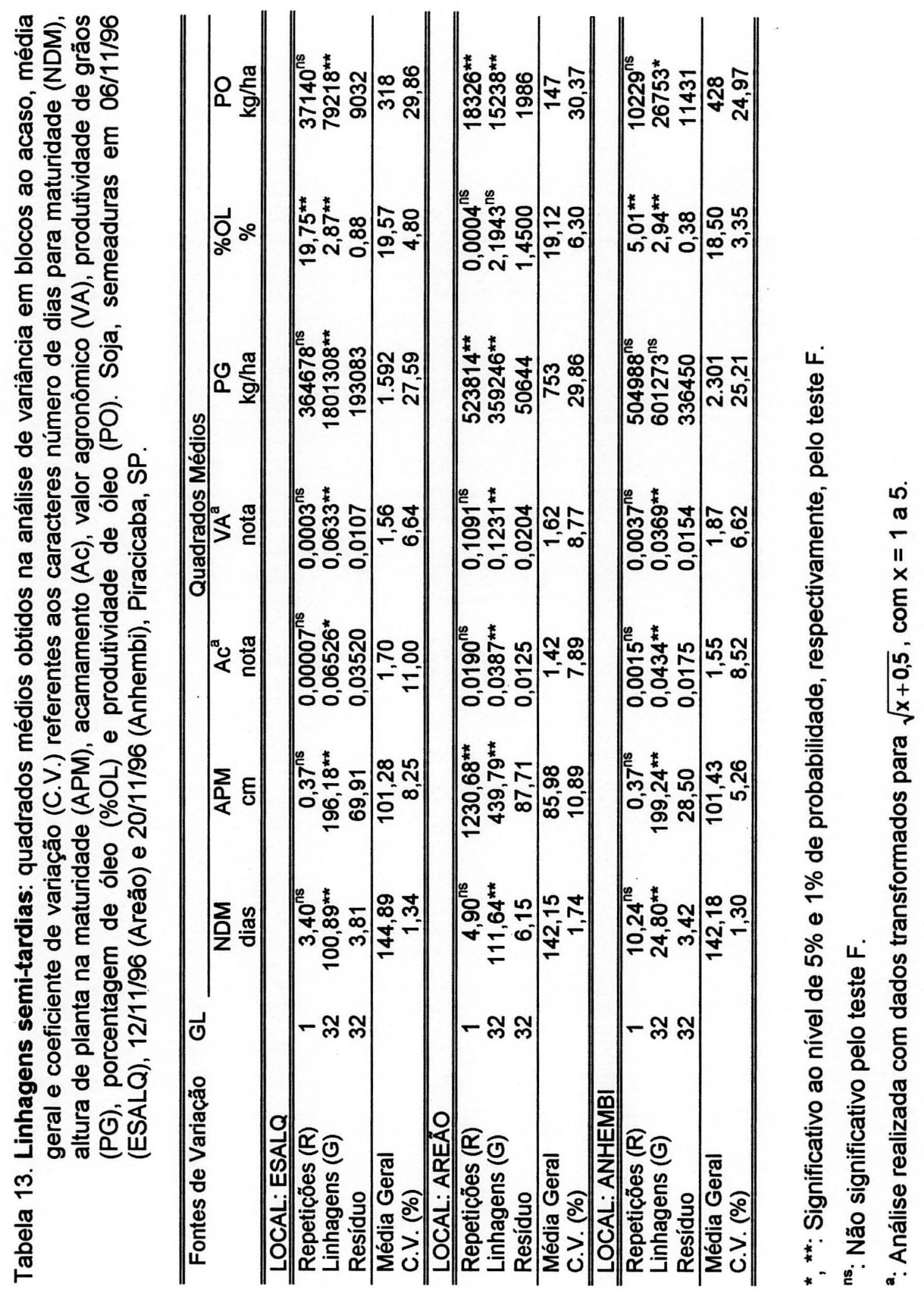



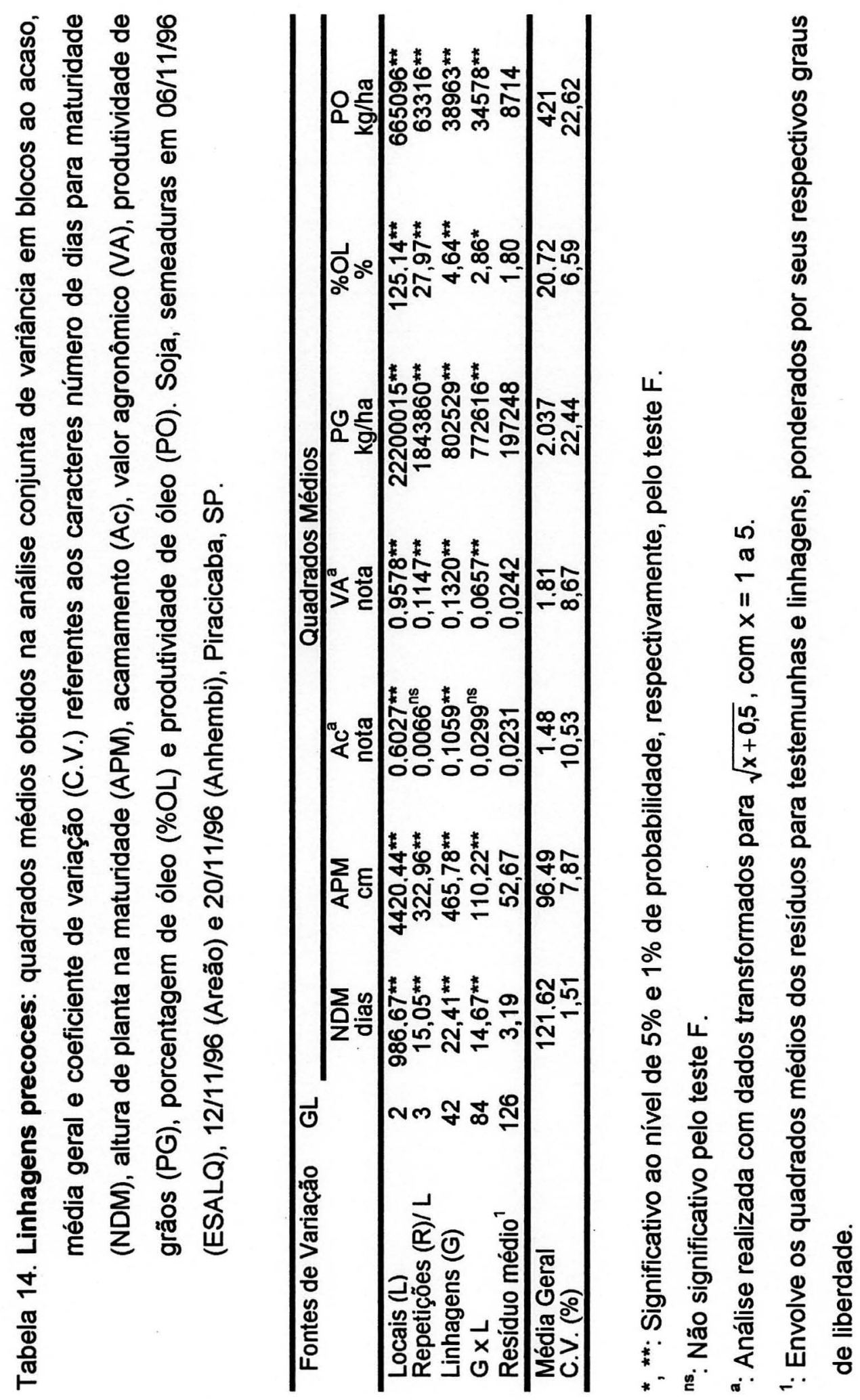


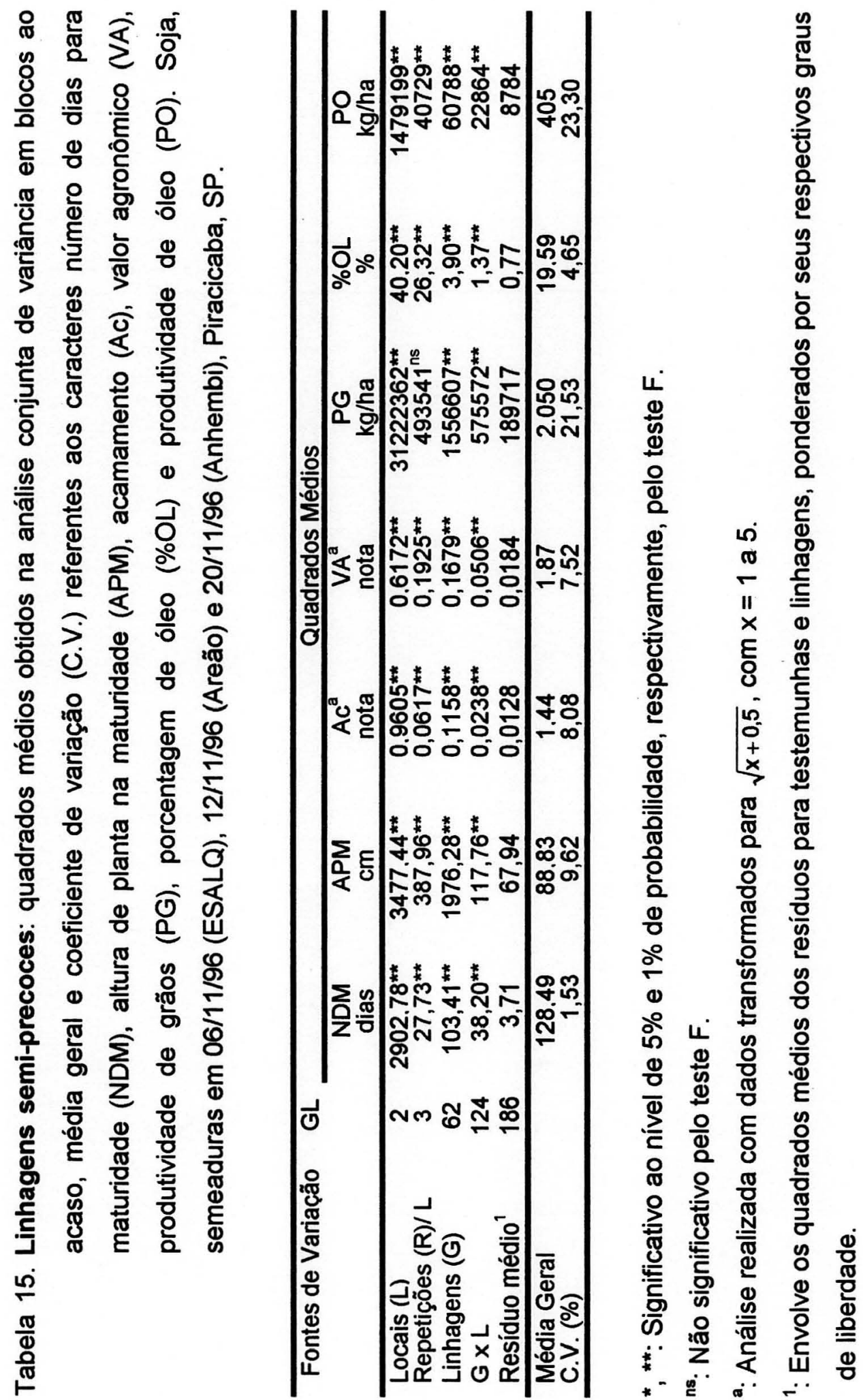



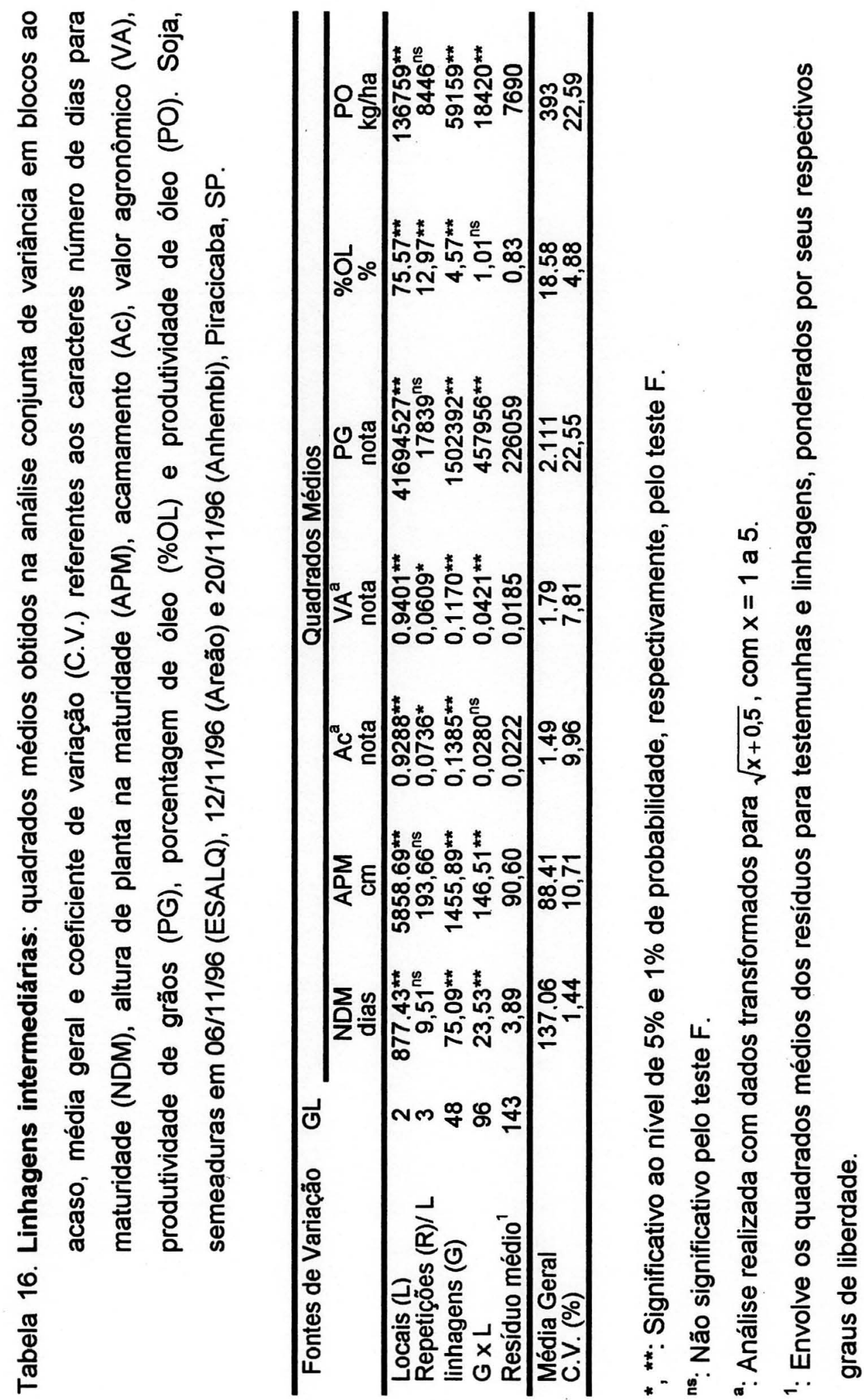


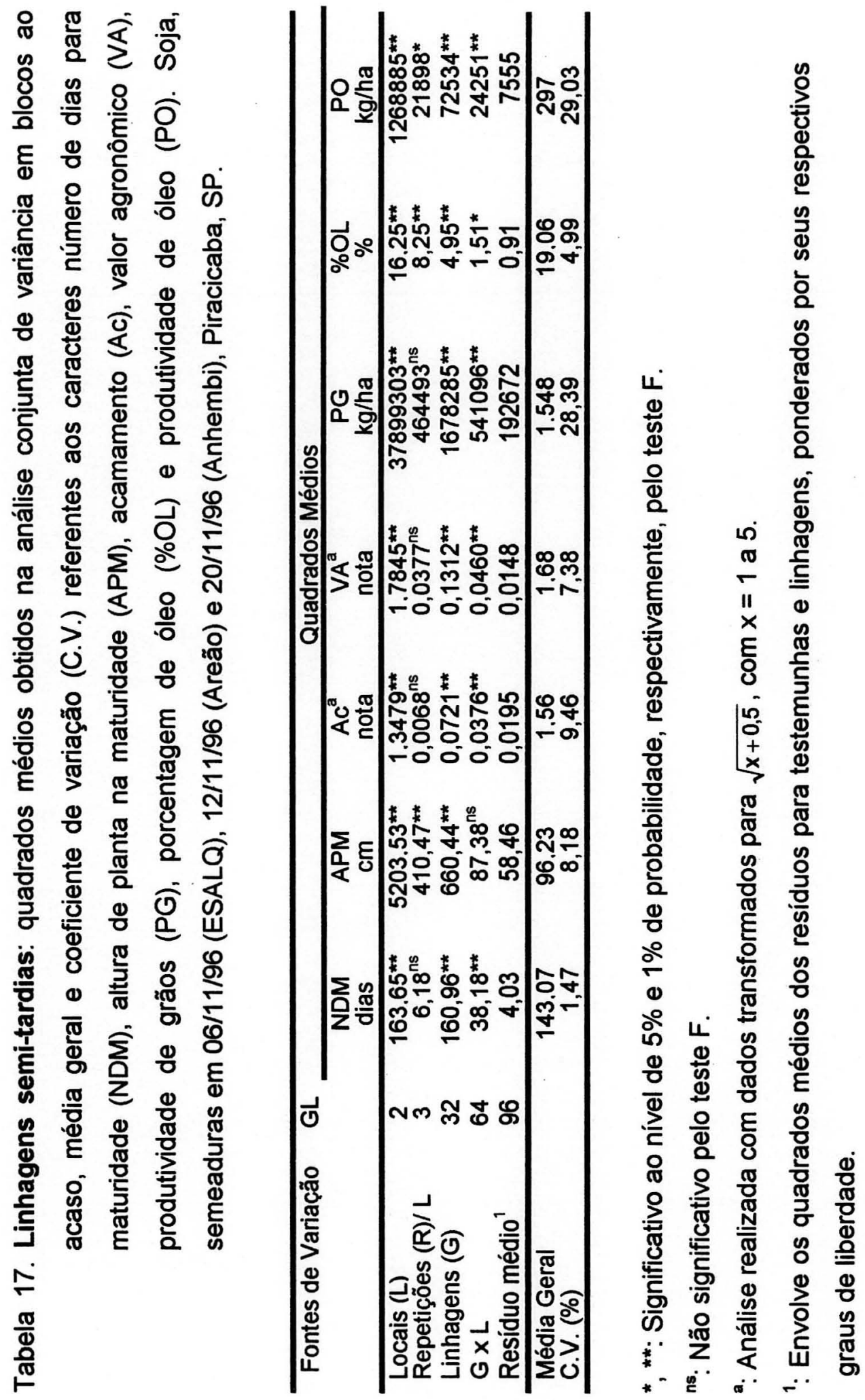




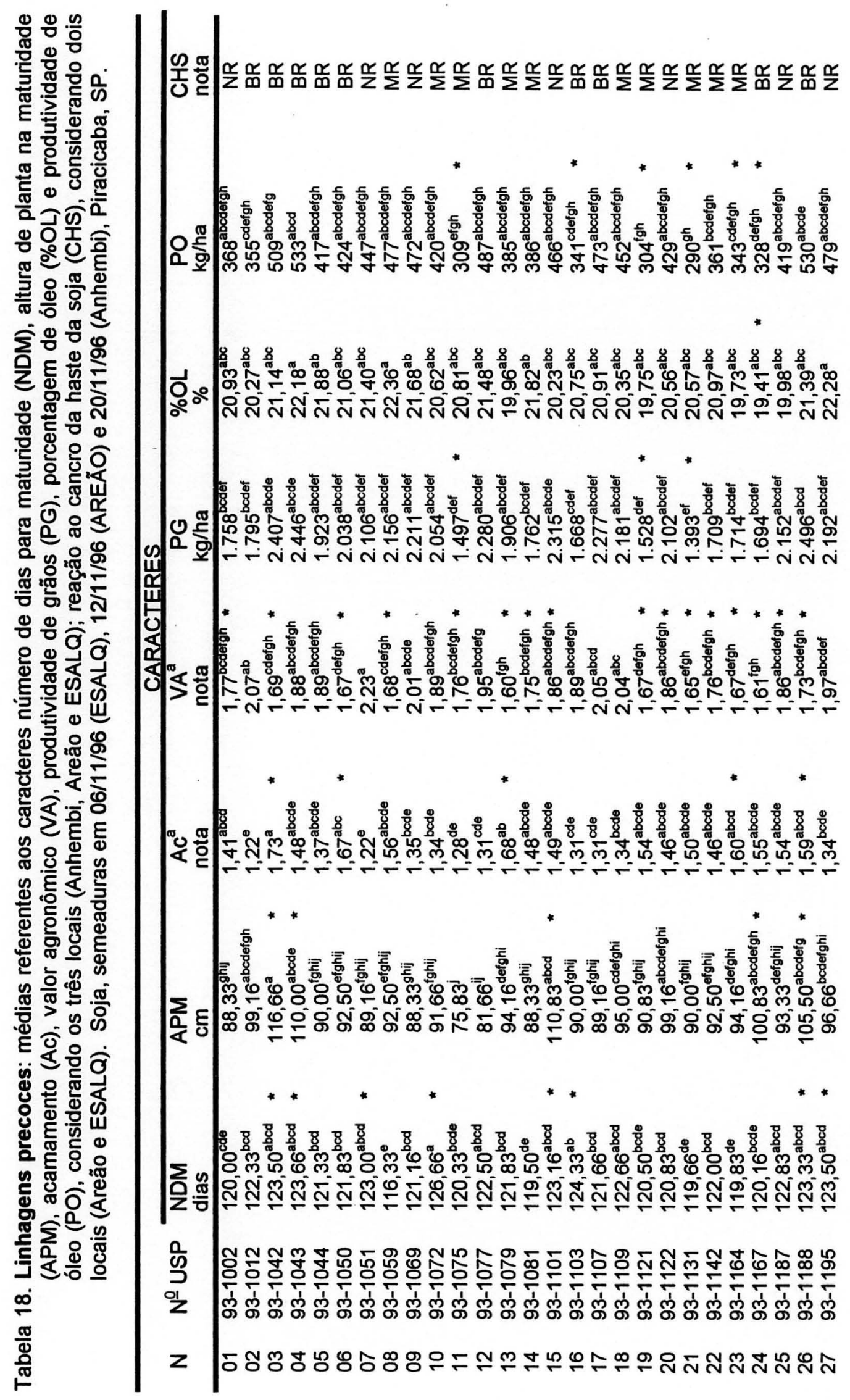




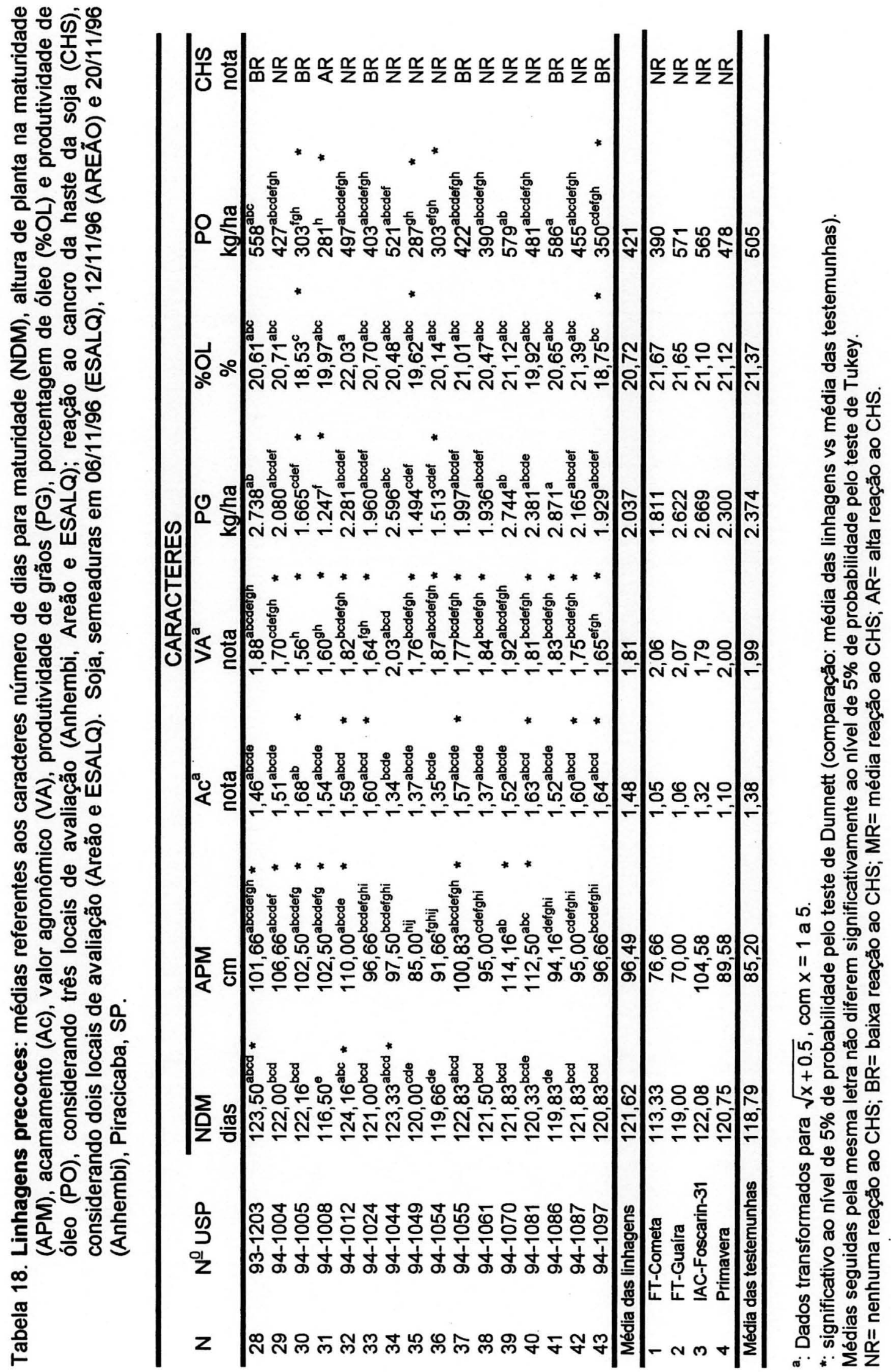




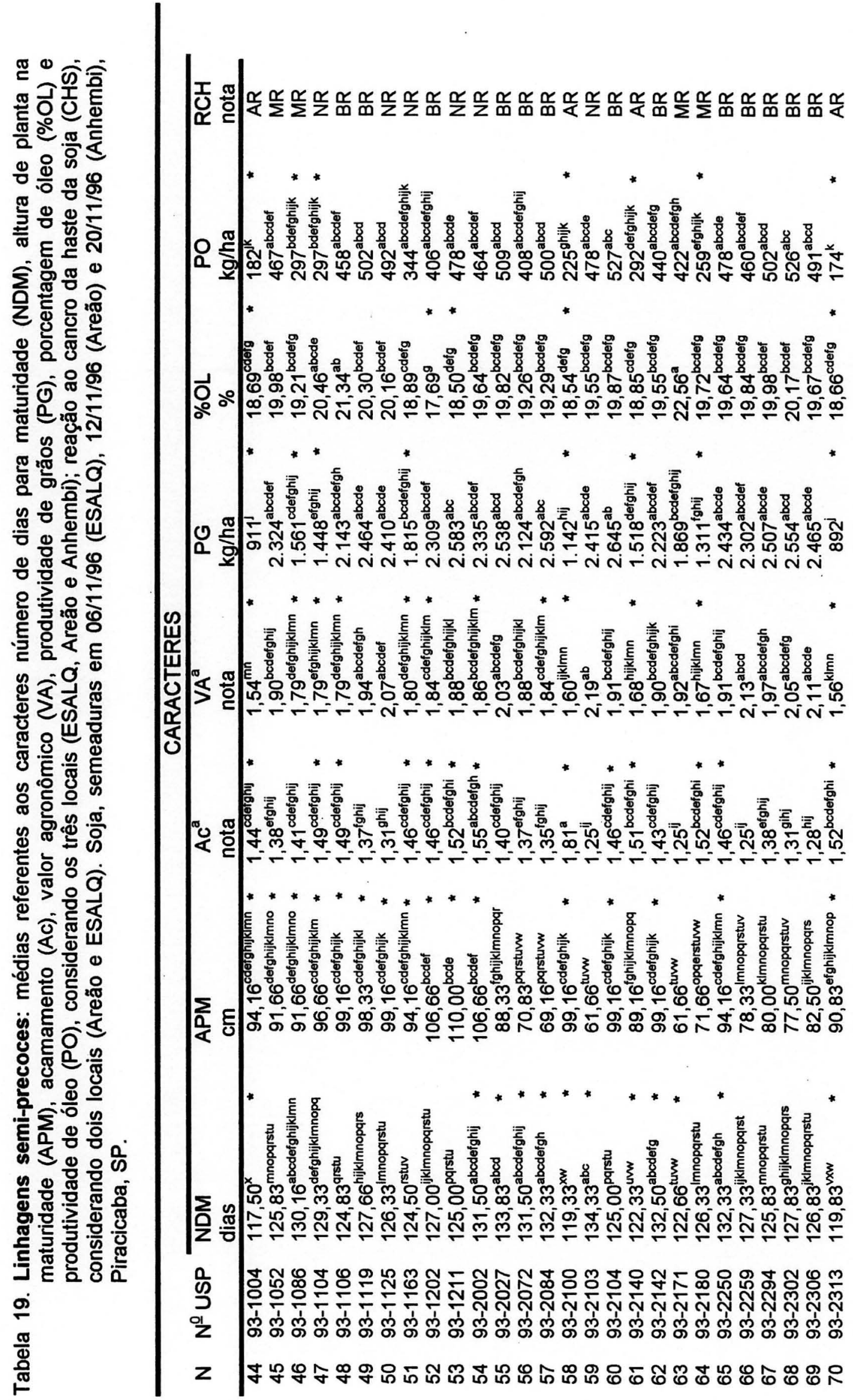

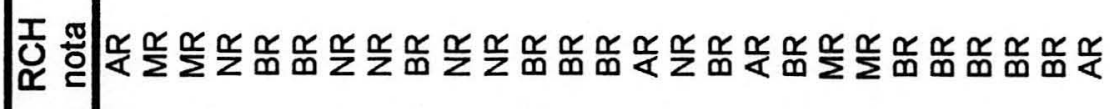




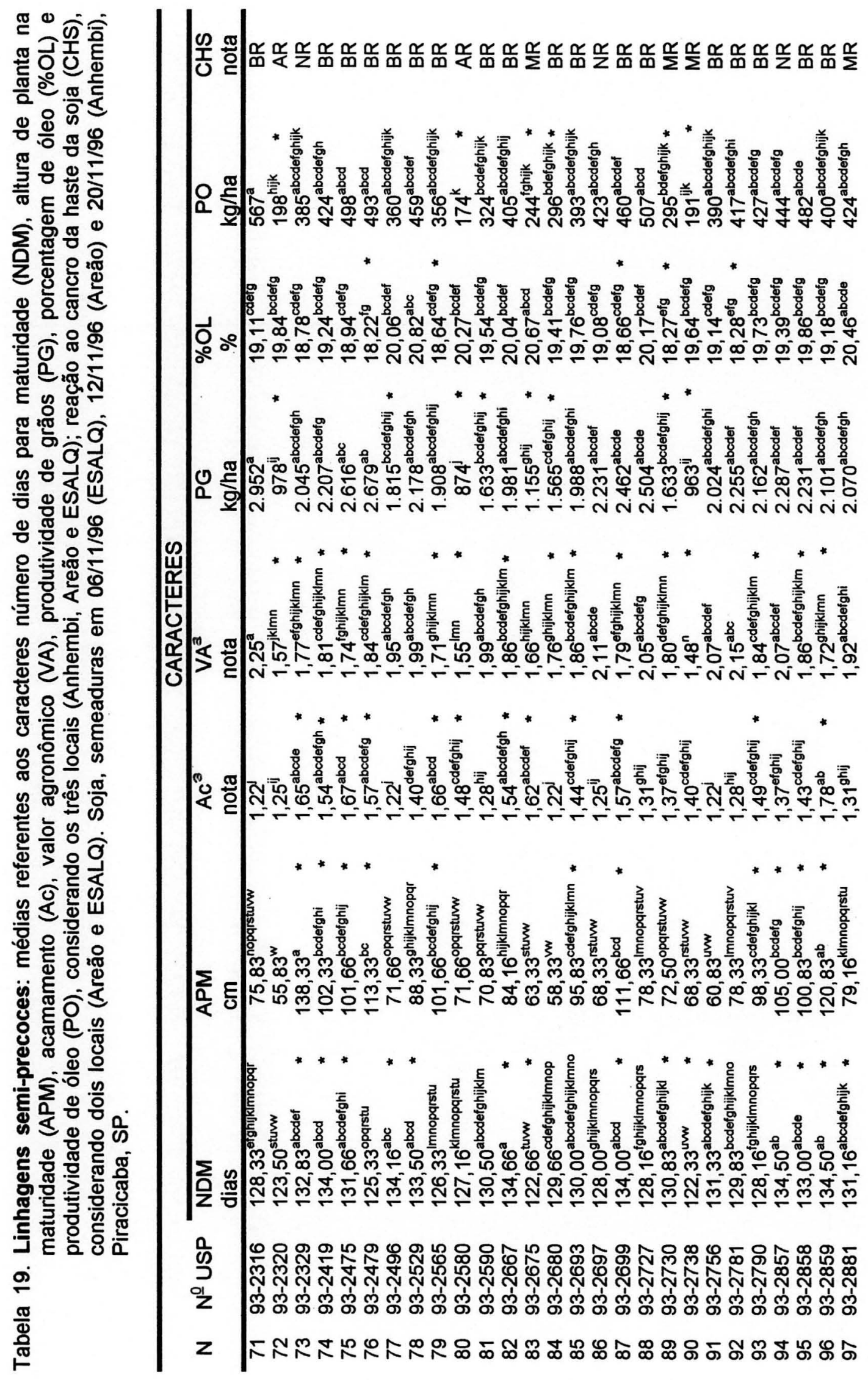




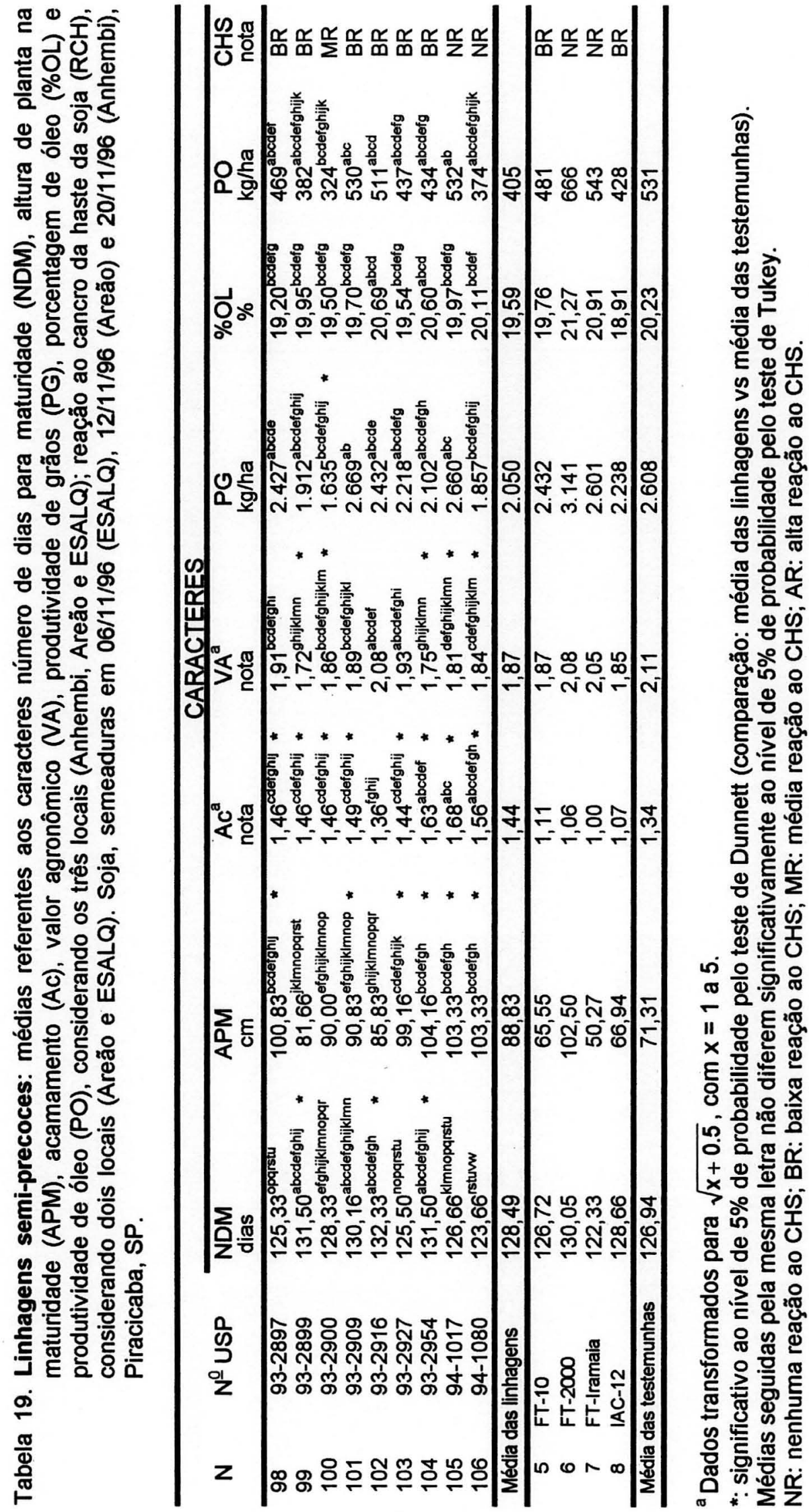




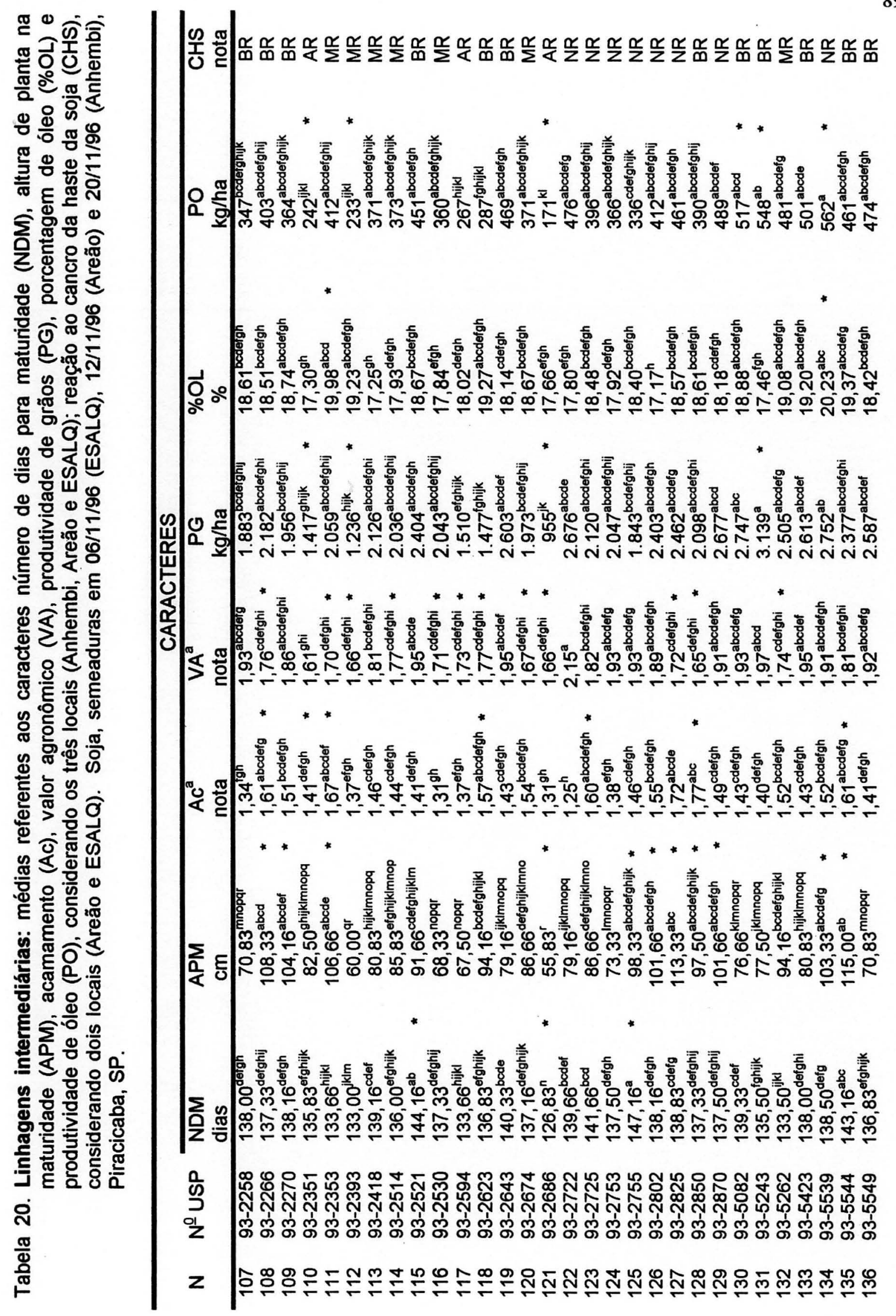




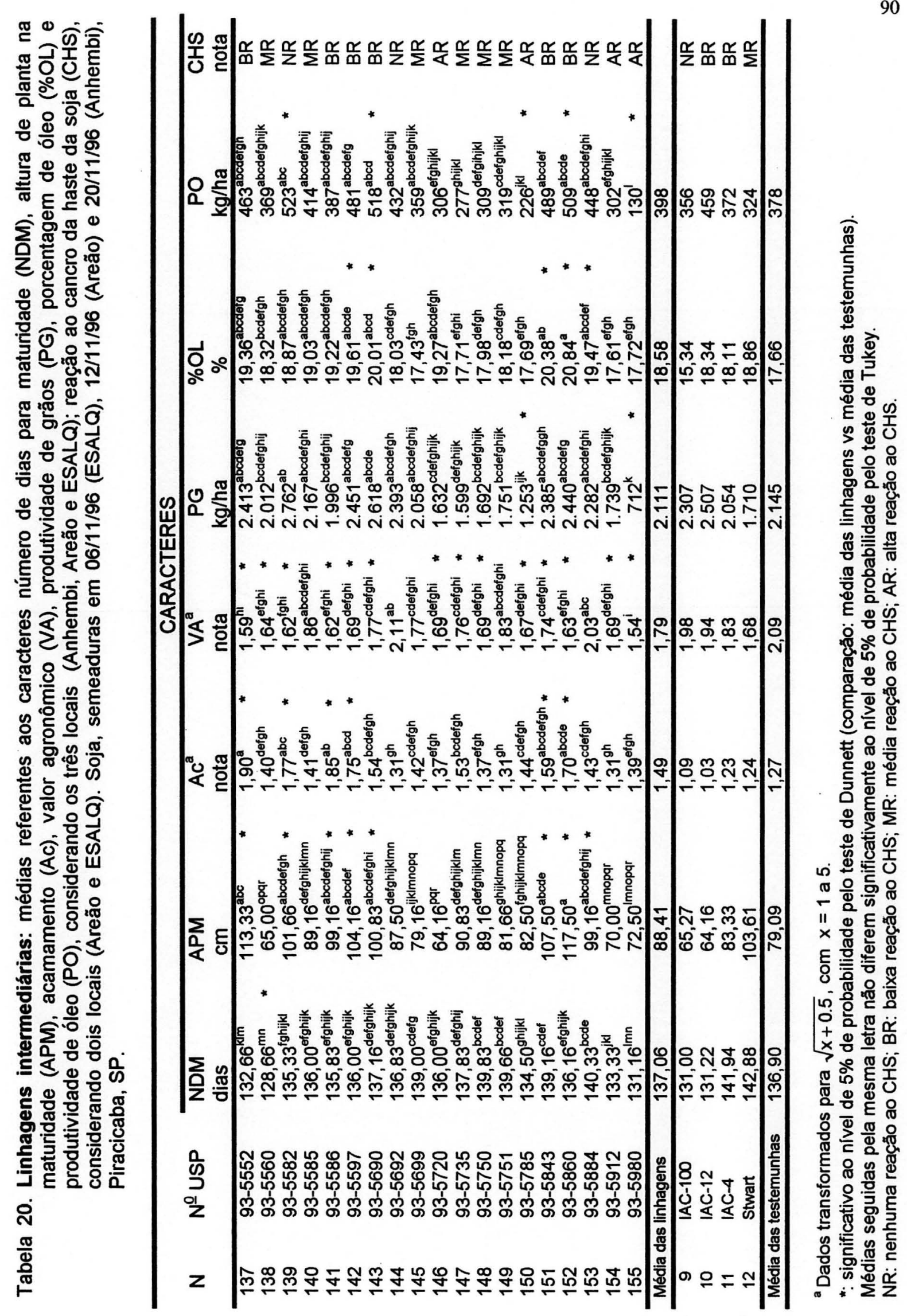




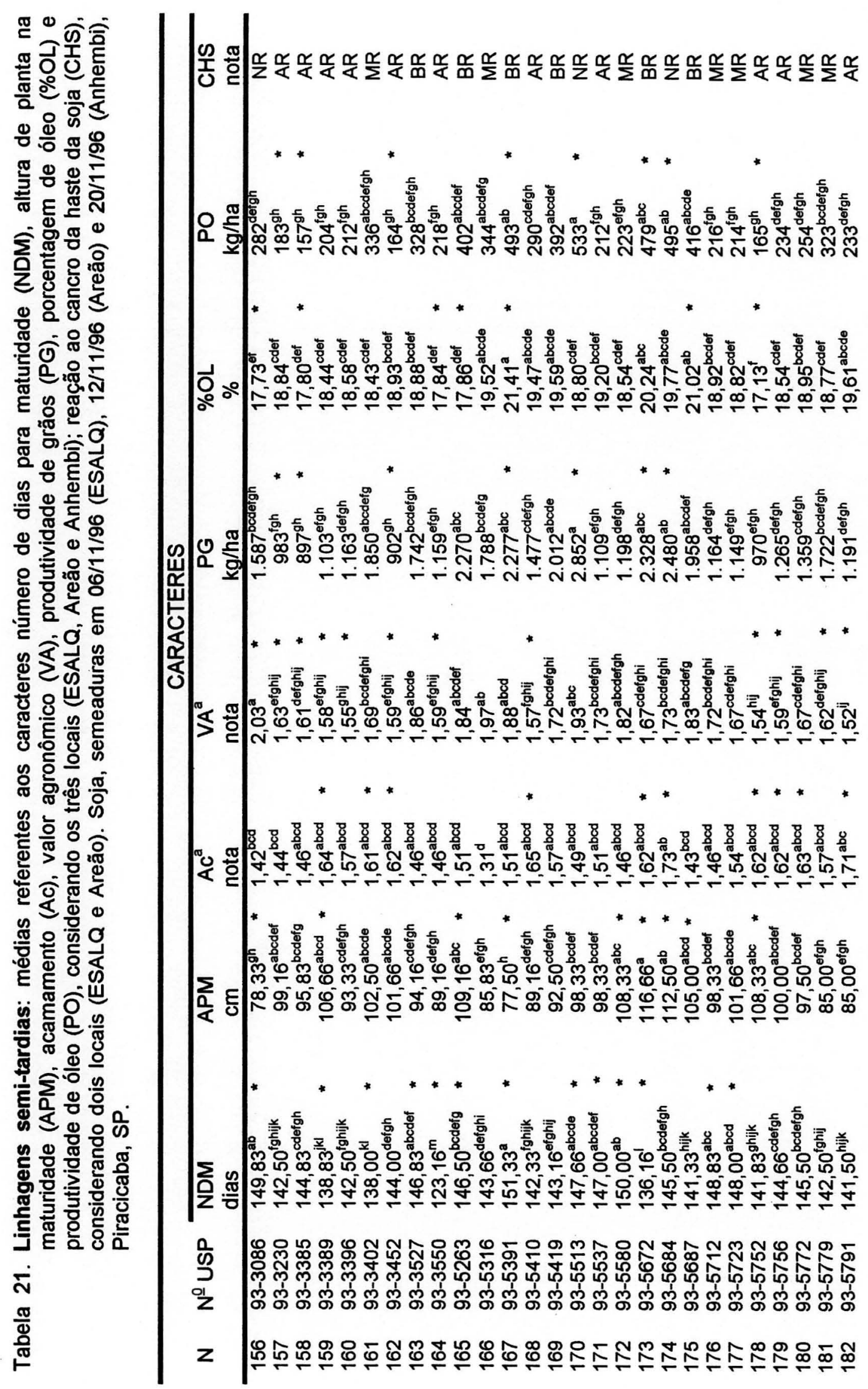




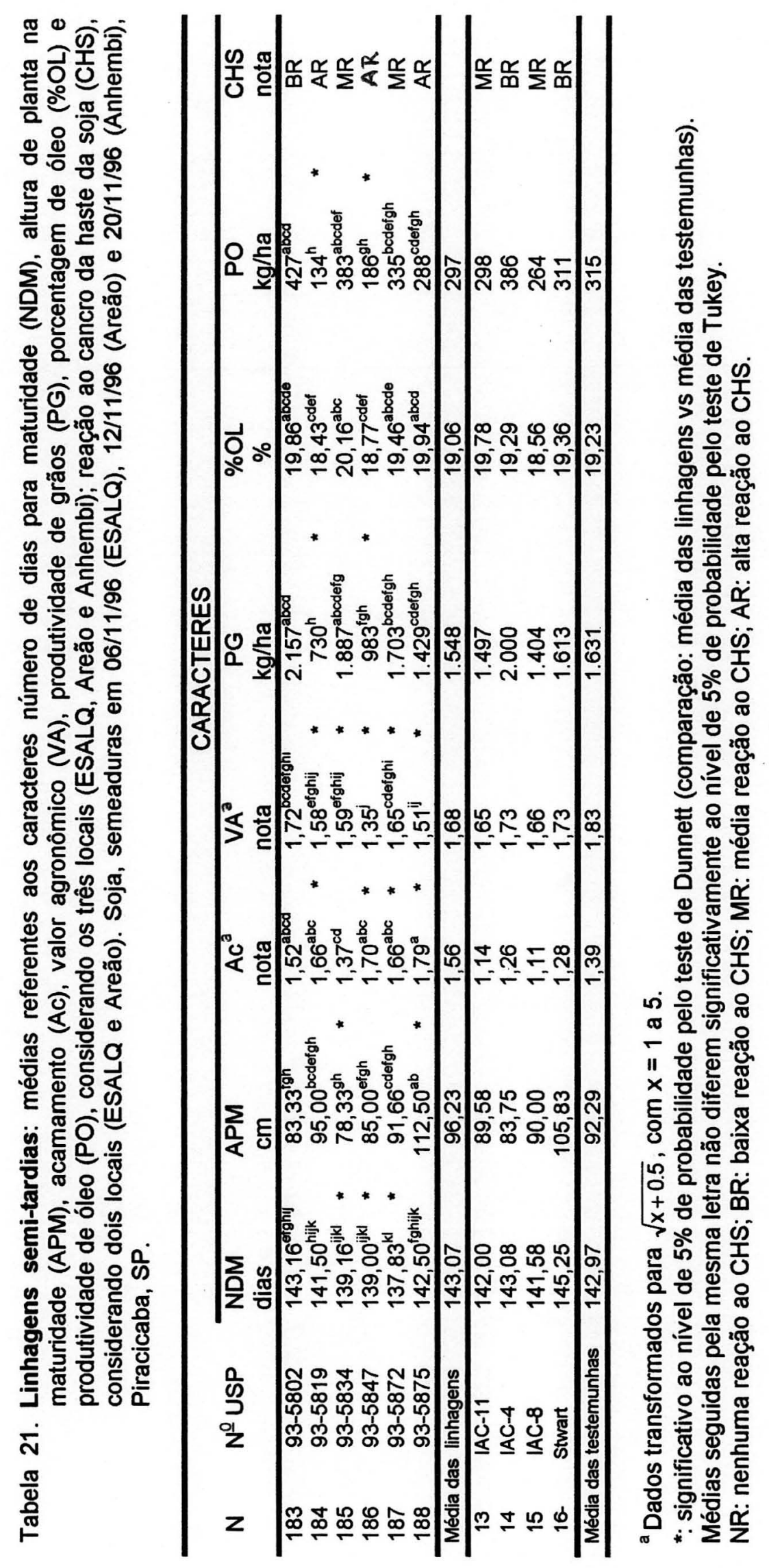


Tabela 22. Médias das 10 melhores linhagens por locais, referentes aos caracteres produtividade de grãos (PG), produtividade de óleo (PO); reação ao cancro da haste da soja (CHS).Soja, semeaduras em 06/11/96 (ESALQ), 12/11/96 (Areão) e 20/11/96 (Anhembi), Piracicaba, SP.

\begin{tabular}{cccccccccc}
\hline $\mathrm{N}$ & N$^{-}$USP & \multicolumn{3}{c}{$\begin{array}{c}\text { PG } \\
\text { (kg/ha) }\end{array}$} & \multicolumn{3}{c}{$\begin{array}{c}\text { PO } \\
\text { (kg/ha) }\end{array}$} \\
\cline { 2 - 9 } & & ESALQ & Areão & Anhembi & ESALQ & Areão & Anhembi & ESALQ & Areão \\
\hline 135 & $93-5243$ & $3.337,5$ & $1.825,0$ & $4.255,0$ & 616,86 & 310,53 & 716,87 & BR & BR \\
71 & $93-2316$ & $3.492,5$ & $2.177,5$ & $3.187,5$ & 660,13 & 412,39 & 627,96 & NR & BR \\
41 & $94-1086$ & $3.462,5$ & $1.730,0$ & $3.420,0$ & 687,12 & 377,93 & 692,98 & BR & NR \\
170 & $93-5513$ & $3.970,0$ & $1.710,0$ & $2.877,5$ & 753,99 & 342,93 & 502,42 & NR & NR \\
142 & $93-5582$ & $3.172,5$ & $2.277,5$ & $2.835,0$ & 622,00 & 446,09 & 499,73 & NR & NR \\
137 & $93-5539$ & $3.305,0$ & $2.070,0$ & $2.882,5$ & 702,31 & 414,12 & 569,08 & NR & NR \\
134 & $93-5082$ & $3.450,0$ & $1.900,0$ & $2.892,5$ & 686,06 & 363,75 & 502,49 & NR & BR \\
39 & $94-1070$ & $3.880,0$ & $1.237,5$ & $3.115,0$ & 807,95 & 247,57 & 682,47 & NR & NR \\
28 & $93-1203$ & $2.880,0$ & $1.657,5$ & $3.677,5$ & 561,13 & 353,64 & 760,32 & BR & BR \\
76 & $93-2479$ & $3.032,5$ & $1.870,0$ & $3.135,0$ & 570,58 & 332,00 & 577,09 & NR & BR \\
\hline
\end{tabular}

$\mathrm{NR}=$ ausência de reação ao $\mathrm{CHS} ; \mathrm{BR}=$ baixa reação ao $\mathrm{CHS}$.

Tabela 23. Ordem de classificação por local das 10 melhores linhagens referentes aos caracteres produtividade de grãos (PG) e produtividade de óleo (PO), considerando as demais linhagens dentro de ciclo de maturação (CM).

\begin{tabular}{ccccccccc}
\hline $\mathrm{N}$ & $\mathrm{CM}$ & $N^{0}$ USP & \multicolumn{3}{c}{$\begin{array}{c}\mathrm{PG} \\
(\mathrm{kg} / \mathrm{ha})\end{array}$} \\
\cline { 3 - 8 } & & & ESALQ & Areão & Anhembi & ESALQ & Areão & Anhembi \\
\hline 135 & $\mathrm{I}$ & $93-5243$ & $4^{2}$ & 11 & 1 & 11 & 18 & 1 \\
71 & $\mathrm{SP}$ & $93-2316$ & 1 & 1 & 3 & 1 & 1 & 6 \\
41 & $\mathrm{P}$ & $94-1086$ & 2 & 8 & 2 & 3 & 9 & 4 \\
170 & $\mathrm{ST}$ & $93-5513$ & 1 & 1 & 5 & 2 & 2 & 9 \\
142 & $\mathrm{I}$ & $93-5582$ & 9 & 1 & 15 & 10 & 1 & 18 \\
137 & $\mathrm{I}$ & $93-5539$ & 6 & 3 & 12 & 2 & 2 & 4 \\
134 & $\mathrm{I}$ & $93-5082$ & 2 & 7 & 11 & 3 & 8 & 17 \\
39 & $\mathrm{P}$ & $94-1070$ & 1 & 37 & 6 & 1 & 38 & 5 \\
28 & $\mathrm{P}$ & $93-1203$ & 15 & 11 & 1 & 15 & 15 & 1 \\
76 & $\mathrm{SP}$ & $93-2479$ & 8 & 6 & 6 & 19 & 13 & 20 \\
\hline
\end{tabular}

a: Ordem de classificação da linhagem dentro de seu ciclo de maturação.

$\mathrm{P}=$ precoce $; \mathrm{SP}=$ semi-precoce $; \mathrm{I}$ = intermediário; $\mathrm{ST}$ = semi-tardio. 


\section{APÊNDICES}


Apêndice 1. Fotoperíodo, temperatura, umidade relativa e precipitação pluviométrica, no período de novembro/96 a Abril/97, relativo à avaliação de linhagens experimentais de soja em Piracicaba, SP.

\begin{tabular}{||ccccccc||}
\hline Mês & $\begin{array}{c}\text { Fotoperíodo } \\
\text { (horas) }\end{array}$ & Média & Máxima & Mínima & $\begin{array}{c}\text { Umidade } \\
\text { relativa } \\
\text { (\%) }\end{array}$ & $\begin{array}{c}\text { Precipitação } \\
\text { pluvial } \\
\text { (mm) }\end{array}$ \\
\cline { 2 - 5 } & & 23,41 & 29,07 & 17,75 & 79,50 & 7,07 \\
\hline Novembro & 6,22 & 25,20 & 30,61 & 19,78 & 84,77 & 6,07 \\
\hline Dezembro & 6,04 & 29,90 & 29,71 & 20,09 & 86,87 & 11,36 \\
\hline Janeiro & 4,21 & 24,90 & 19,50 & 79,50 & 3,11 \\
\hline Fevereiro & 7,55 & 24,73 & 31,73 & 19,0 & 73,29 & 2,36 \\
\hline Março & 7,65 & 23,72 & 29,94 & 17,50 & 73,20 & 0,73 \\
\hline Abril & 7,57 & 21,85 & 28,68 & 15,02 & \\
\hline
\end{tabular}

Fonte: Departamento de Física e Meteorologia - ESALQ/USP.

Apêndice 2a. Critérios utilizados para a interpretação de análises de solos para o Estado de São Paulo.

\begin{tabular}{||cc||ccccccc||}
\hline Acidez & $\begin{array}{c}\mathrm{pH} \\
\mathrm{CaCl}\end{array}$ & Níveis & $\mathrm{M} .0$ & $\mathrm{P}$ & \multicolumn{3}{c|}{$\mathrm{Meq} / 100 \mathrm{~g}$} & $\mathrm{~V}$ \\
\cline { 5 - 9 } & & & $(\%)$ & $\left(\mu \mathrm{g} / \mathrm{cm}^{3}\right)$ & $\mathrm{K}$ & $\mathrm{Ca}$ & $\mathrm{Mg}$ & $(\%)$ \\
\hline Muito baixa & $>6,0$ & Muito baixo & - & 6,0 & 0,07 & - & - & $\leq 25$ \\
\hline Baixa & $5,6-6,0$ & Baixo & 1,5 & $7,08-15,0$ & $0,08-0,15$ & 0,4 & 0,4 & $26-50$ \\
\hline Média & $5,1-5,5$ & Médio & $1,5-2,5$ & $0,15-40,0$ & $0,16-30,0$ & $0,5-0,8$ & $0,5-0,8$ & $51-70$ \\
\hline Alta & $4,45,0$ & Alto & $>2,5$ & $>80,0$ & $>80,0$ & - & - & $71-90$ \\
\hline Muito alta & $<4,3$ & Muito alto & - & - & - & - & - & $>90$ \\
\hline
\end{tabular}

Fonte: Malavolta et al., 1989.

Apêndice $2 b$. Análises químicas do solo nas áreas de pesquisa com soja, nos locais Anhembi, Areão e ESALQ, Piracicaba, SP.

\begin{tabular}{||cccccccc||}
\hline Local & $\begin{array}{c}\mathrm{pH} \\
\mathrm{CaCl}_{2}\end{array}$ & $\begin{array}{c}\mathrm{M} . \mathrm{O} \\
(\%)\end{array}$ & $\begin{array}{c}\mathrm{P} \\
\left(\mu \mathrm{g} / \mathrm{cm}^{3}\right)\end{array}$ & $\mathrm{K}$ & $\mathrm{Meq} / 100 \mathrm{~g}$ & $\mathrm{Ca}$ & $\begin{array}{c}\mathrm{V} \\
(\%)\end{array}$ \\
\hline Anhembi $^{1}$ & 6,0 & - & 55 & 0,23 & 2,9 & 2,3 & 90 \\
\hline Areäo $^{2}$ & 4,3 & 1,6 & 15 & 0,26 & 3,6 & 1,2 & 50 \\
\hline ESALQ $^{1}$ & 5,4 & - & 45 & 0,40 & 3,3 & 1,1 & 61 \\
\hline
\end{tabular}

Fonte: ${ }^{1}$ : Departamento de Química - ESALQ/USP.

2: Departamento de Ciência do Solo - ESALQ/USP. 
Apêndice 3. Programa em SAS versão 6.11, que executa análise de resíduo. Exemplo do caráter PG, local Areão, ciclo de maturação semi-precoce. Soja, Piracicaba, SP, semeadura em 12/11/96.

DATA ARSP;

INPUT REP TRAT NDM APM AC VA PG OL PO;

CARDS;

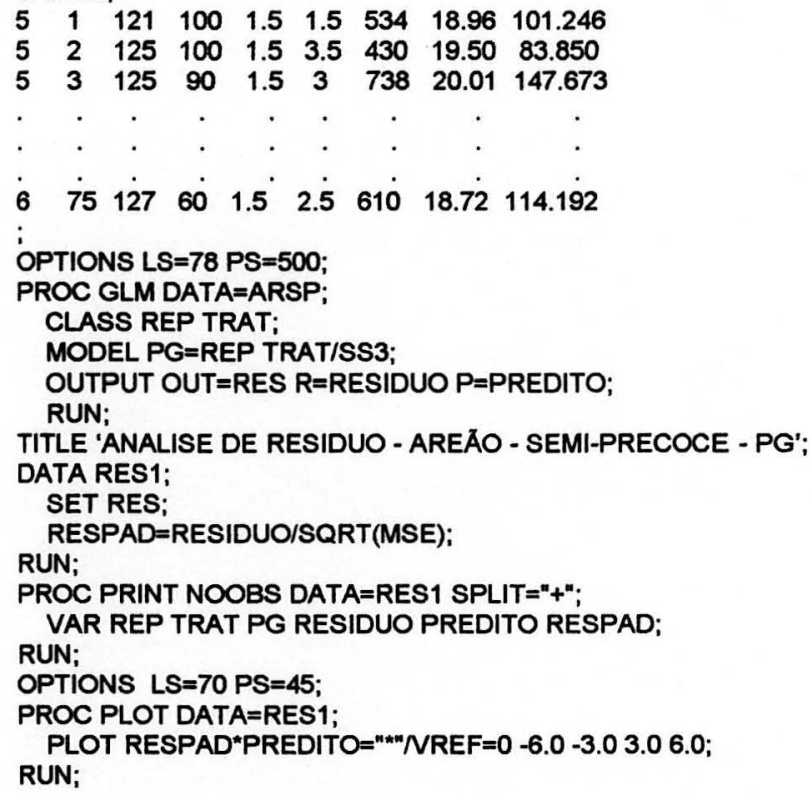

Apêndice 4. Programa em SAS versão 6.11, que executa análise de variância conjunta em blocos ao acaso com estratificação em conjuntos experimentais para testemunhas. Exemplo do caráter PG, ciclo de maturação semi-tardio. Soja, Piracicaba, SP, semeaduras em 06/11/96 (ESALQ), 12/11/96 (Areão) e 20/11/96 (Anhembi).

DATA CSTT;

INPUT LOC REP CONJ TEST NDM APM AC VA EST PG OL PO;

$A C T=S Q R T(A C+0.5) ; V A T=S Q R T(N A+0.5)$;

CARDS;

$\begin{array}{lllllllllllll}1 & 1 & 1 & 13 & 145 & 105 & 2 & 2.5 & 5 & 802 & 19.45 & 155.989\end{array}$

$\begin{array}{llllllllllll}1 & 1 & 1 & 14 & 143 & 80 & 2 & 2.5 & 4.5 & 1236 & 19.16 & 236.817\end{array}$

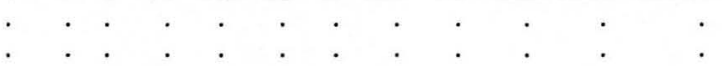

$\begin{array}{llllllllllll}2 & 4 & 2 & 16 & 141 & 110 & \dot{1} & 4.5 & 4.5 & 948 & 18.95 & 179.646\end{array}$

OPTIONS LS $=78$ PS $=500$

TITLE'ANAVA CONJUNTA DE TESTEMUNHAS-SEMI-TARDIO-CARÁTER:PG';

PROC GLM DATA $=$ CSTT:

CLASS LOC REP CONJ TEST;

MODEL PG=REP(LOC) LOC TEST CONJ TEST*CONJ TEST*LOC CONJ*LOC TEST*CONJ"LOC/SS3;

RUN;

TITLE'FREQUÊNCIA, MÉDIA, VARIÂNCIA E DESVIO PADRÃO';

PROC SORT:

BY TEST;

RUN;

PROC MEANS MEAN VAR STD NOPRINT;

VAR PG;

BY TEST;

OUTPUT OUT=MEDIAS MEAN=MEDIA VAR=VARIAN STD=DESVPAD;

RUN;

PROC SORT DATA=MEDIAS;

BY DESCENDING MEDIA;

RUN;

PROC PRINT DATA=MEDIAS;

RUN; 


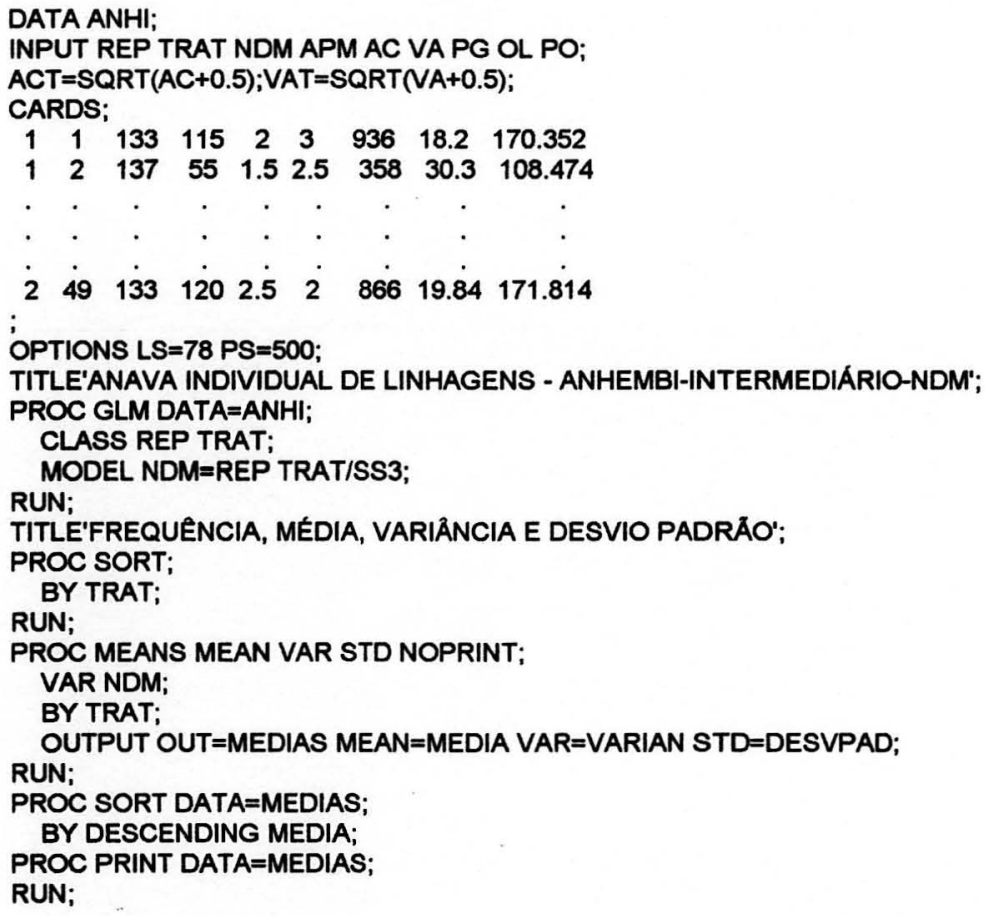

Apêndice 6. Programa em SAS versão 6.11, que executa análise de variância conjunta em blocos ao acaso para linhagens. Exemplo do caráter PG, ciclo de maturação precoce. Soja, Piracicaba, SP, semeaduras em 6/11/96 (ESALQ), 12/11/96. (Areão) e 20/11/96 (Anhembi).

DATA CPL

INPUT LOC REP TRAT NDM APM AC VA PG OL PO;

$A C T=S Q R T(A C+0.5) ; V A T=S Q R T(V A+0.5)$;

CARDS;

$\begin{array}{lllllllllll}1 & 1 & 1 & 125 & 85 & 1 & 5 & 624 & 20.95 & 130.728\end{array}$

$\begin{array}{lllllllllll}1 & 1 & 2 & 127 & 95 & 1.5 & 3 & 1002 & 20.50 & 205.410\end{array}$

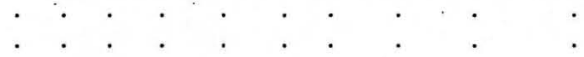

$\begin{array}{llllllllll}3 & 6 & 43 & 119 & 90 & 1.5 & 4 & 718 & 21.36 & 153.364\end{array}$

OPTIONS LS $=78$ PS $=500$

TITLE'ANAVA CONJUNTA DE LINHAGENS-PRECOCE-PG';

PROC GLM DATA=CPL

CLASS LOC REP TRAT:

MODEL PG=LOC REP(LOC) TRAT TRAT*LOC/SS3;

MEANS TRAT/TUKEY;

RUN;

TITLE'FREQUÊNCIA, MÉDIA, VARIÂNCIA E DESVIO PADRÃO';

PROC SORT;

BY TRAT;

RUN;

PROC MEANS MEAN VAR STD NOPRINT;

VAR PG;

BY TRAT:

OUTPUT OUT=MEDIAS MEAN=MEDIA VAR=VARIAN STD=DESVPAD;

RUN;

PROC SORT DATA=MEDIAS;

BY DESCENDING MEDIA;

RUN:

PROC PRINT=MEDIAS;

RUN; 
Apêndice 7. Programa em SAS versão 6.11, que executa análise de variância conjunta em blocos ao acaso com a aplicação do teste de Dunnett (linhagens vs média das testemunhas). Exemplo do caráter PG, ciclo de maturação intermediário. Soja, Piracicaba, SP, semeaduras em 6/11/96 (ESALQ), 12/11/96 (Areão) e 20/11/96 (Anhembi).

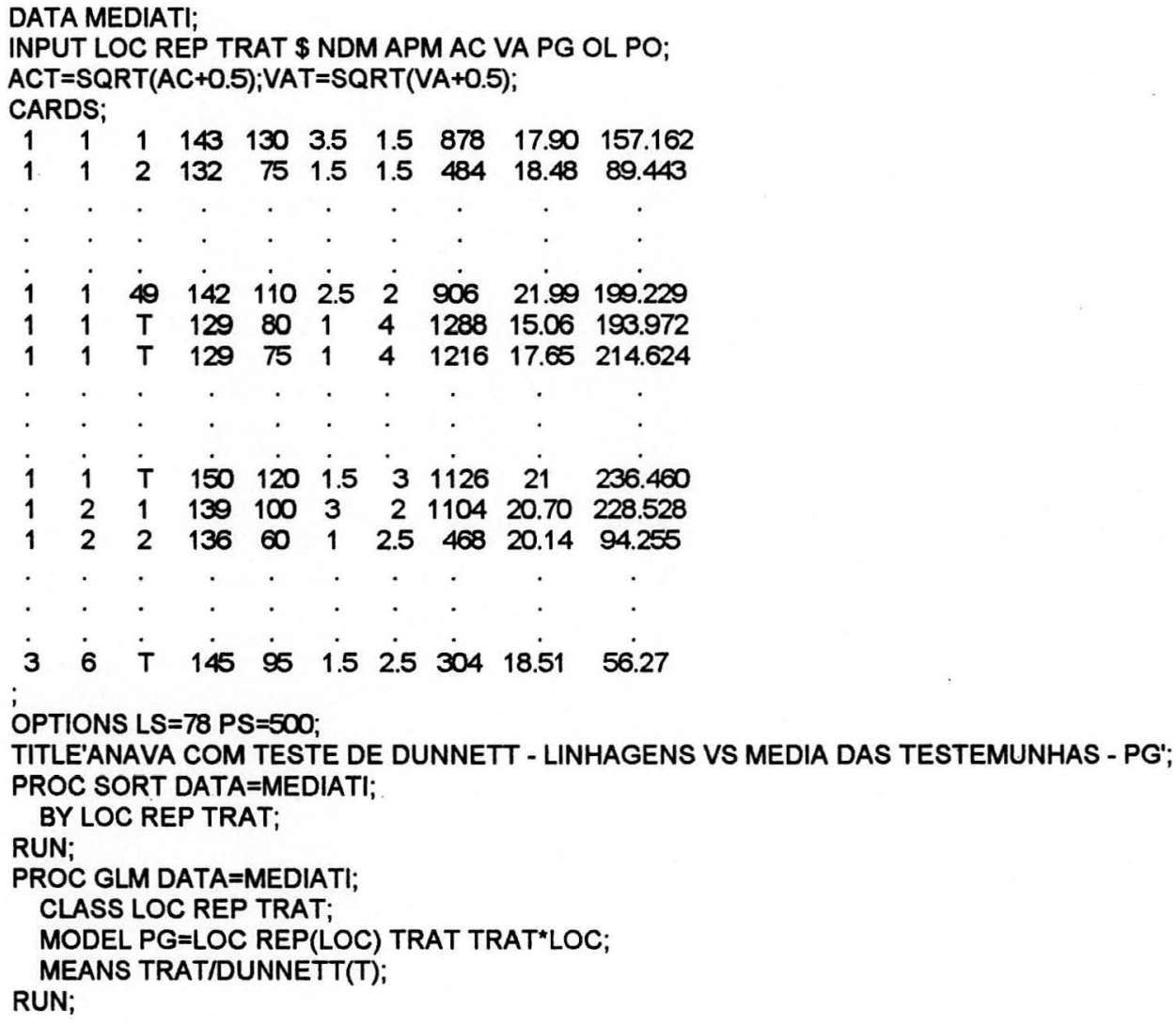

